Hispania Sacra, LIX

120, julio-diciembre 2007, 633-706, ISSN: 0018-215-X

\title{
ALFRED LOISY, MÁS ALLÁ DEL RUIDO Y DEL HUMO. «QUI PERDIDERIT ANIMAM SUAM SALVAM FACIET EAM» (Marc VIII, 35)
}

\author{
POR \\ CRistóbal Robles MuÑoz \\ Instituto de Historia, CSIC*
}

\section{RESUMEN}

Loisy y el modernismo se identicaron durante años. Este trabajo pretende, más allá del ruido y del humo, contribuir a que no se pierda en el olvido ni la persona ni las razones de Alfred Loisy, uno de los más afectados por la crisis modernista. Hemos recurrido sobre todo a a sus Mémoires. Loisy no necesitó esperar años para recibir el homenaje que merece una persona que no se ha traicionado.

Palabras ClaVe: Loisy, modernismo, Mémoires Iglesia Pascendi Dominici Gregis y Lamentabile sane.

\begin{abstract}
Loisy and the modernism were identified during years. This work tries, beyond the noise and the smoke, to contribute not to loose in the forgetfulness neither the person nor the reasons of Alfred Loisy, one of the most affected by the modernist crisis. We have resorted mainly to his Mémoires. Loisy did not need to hope years to receive the tribute that deserves a person who has not betrayed itself.
\end{abstract}

* Siglas

ASV: Archivio Segreto Vaticano Fondo Benigni caja documentoi folio

ASV SS : Archivio Segreto Vaticano Segreteria di Stato rúbrica, año, fascículo y folios

Fonti e Documenti: Centro Studi per la Storia del Modernismo. Istituto di Storia dell'Univerità di Urbino, numero, año y páginas. 
KEY WORDS: Loisy, modernism, Mémoires, Catholic Church, Pascendi, Dominici Gregis y Lamentabile sane.

Recibido/Received 30-04-2007

Aceptado/Accepted 23-06-2007

Fue Loisy uno de los más afectados por la crisis modernista. Le afectó antes que a otros. Le afectó más profundamente. Le afectó de manera más decisiva. No se reconcilió con la Iglesia como hizo Murri. Algunos, como aparecerá más abajo, le acusaron de haber mantenido dolosamente oculta su crisis. Otros debatieron con él los presupuestos en los que asentaba su trabajo y la fidelidad a sus compromisos. Otros se alejaron de él hostiles o indiferentes. Este sabio, retirado varios meses cada año a su casa en un pueblo pequeño, huido de París, a la que se imaginaba como su «Babilonia», ¿cómo y por qué tuvo tanta autoridad entre los que lo trataron?

Desde Roma decretaron que su persona era «vitanda». Quiseron que fuera un apestado. Cuando terminó sus memorias, en 1930, pidió que lo dejaran morir en paz. Sabía que nadie podría apartarlo de quien creía como el Bien, porque es el sumamente bueno. La fuerza de esa certeza le bastaba para resistir y poder decir confiadamente, «tuam in votis tenuit voluntatem» ${ }^{1}$. No le faltó la amistad de quienes replicaron a los que exigieron su salida. Para mi, decía el arzobispo de Albi, Eudoxe Irenée Mignot ${ }^{2}$, será siempre una persona digna de amor y estima. El arzobispo estaba del lado de la gente buena. Creía que la ternura es la luz más potente que podemos dar a quien yerra y la llamada más acogedora que puede recibir quien se aleja ${ }^{3}$. Este trabajo pretende, más allá del ruido y del

${ }^{1}$ En 1930, Guitton, discípulo suyo en el Collège de France, lo visitó en su casa de Moutiers-en Der, diez años antes de su muerte. Loisy, comenta Guitton, había separado a Cristo del Nazareno y a Cristo. de la Iglesia. En contraste con Bergson, aparecía Loisy ante el mundo católico «comme s'il était entouré d'une zone de malédiction», Detalles sobre esta visita, Jean GuITTON, Dialogues avec Monsieur Pouget sur la pluralité des Mondes, le Christ des Évangiles, l'avenir de notre espèce, Paris, Grasset 1954, 91, 93 y 105. Loisy le entregó entonces su diurnal y le pidió que rezara por él. Le mostró el epitafio que deseaba sobre su tumba: «A Loisy, sacerdote, retirado de su ministerio y de la enseñanza, profesor en el Colegio de Francia». Debajo esta frase: «Qui tuam in votis tenuit voluntatem». «Yo, como Renán, me explicó, he mantenido mis promesas: in votis, es decir, «en mis deseos». Jean Guitton, Retrato del Padre Lagrange. El que reconcilió la ciencia con la fe, Madrid 1993, 97-98.

2 Recordando una carta de Mignot, escrita el 6 de noviembre de 1904, Loisy comenta desde Garnay: «...l'on peut à peine soupçonner ce qu'a souffert un homme tel que Mgr Mignot durant les quinze dernières années de sa vie, surtout pendant le règne de Pie $X$, véritable sabbat du fanatisme et de la déraison». Alfred LoISY, Mémoires pour servir à l'histoire religieuse de notre temps tome II (1900-1908), Paris, Émile Nourry 1931, 420.

3 «Je regarde Pie X comme un saint... mais ce fut un saint redoutable... Pie X n'était pas bon... parce qu'il était implacable quand il était en jeu ce qu'il croyait être les intérêts de N. S. et dont il se regardait avec raison comme le dépositaire... Comment pourrait-il en être autrement chez un homme qui se croit mandat de faire pénétrer per fas et nefas, la théorie qu'il se fait des droits de Dieu et de J. C.?».

Hispania Sacra, LIX

120, julio-diciembre 2007, 633-706, ISSN: 0018-215-X 
humo, contribuir a que no se pierda en el olvido ni la persona ni las razones de Alfred Loisy, tal como aparecen en los tres tomos de sus Mémoires ${ }^{4}$.

El mismo año en que se editó su último volumen, su amigo, Henri Bremond, lo defendió en su polémica con Blondel. Loisy había sido fiel, «"pas trahi sa cause de savant, pas trahi l'Église romaine y pas trahi la religion... Il ne préfere ni sudordinne une de ses missions à l'autre... Sa philosophie religieuse est discutable, comme toutes les philosophies; sa probité, ne l'est pas"». La forma en que Loisy vivió su condición de sacerdote esta reflejada en esos tres volúmenes. Su vida «était vouée au service de l'Église moyannement la science et les bagatelles académiques ou autres ne le fascinaient point ${ }^{5}$.

Nacido 18 de febrero de 1857, ingresó en el seminario de la diócesis de Châlons en 1874. Completó sus estudios en el Instituto Católico de París entre 1878-1879. Regresaría en 1881 como profesor de hebreo. Su formación transcurre durante la etapa final del largo pontificado de Pío IX.

¿Cómo se recuerda Alfred Loisy cuando ya ha vivido más de setenta años? A partir del Syllabus y de la Quanta Cura, se inició una identificación entre la cultura del XIX y el racionalismo, condenado en esos documentos. Ser independiente se identificaba con mal espíritu. Un superior del seminario de Châlons le dijo: ni somos sabios ni elocuentes, somos la autoridad y ese dato era la razón para que se les respetara y obedeciera.

«C'est en vertu du même principe que les inquisiteurs opéreraient encore si les mœurs et la législation n'y mettaient obstacle. Quelle dureté de ton et d'expressions dans beaucoup d'encycliques de Pie $\mathrm{X}$. Comme on y sent le juge impitoyable. Pas un mot de tendresse pour les errants. Ce n'est pas un pére qui parle, même pas un beau-pére; c'est une belle-mère. Tous en voulant ramener à Jésus, il en éloigne». Journal 20 y 25 agosto 1914, en Louis-Pierre Sardella, Mgr. Eudoxe Irénée Mignot (1842-1918). Un évêque français au temps du modernisme, Paris, Cerf 2004, 494-496.

${ }^{4}$ El 1 de junio de 1933 la Congregación del Santo Oficio condenó la obra de A. LoISY, Mémoires... tras editarse el tercer volumen, Paris 1931. El decreto, condenando diferentes obras de Ernesto Buonaiuti y todas sus obras, el 17 de junio de 1944, lleva la fecha del 13 de mayo de 1950, Doctrina Pontificia. I Documentos Bíblicos, edición preparada por Salvador Muñoz Iglesias, Madrid, Editorial Católica, BAC 1955, 319. Los decretos referidos a Buonaiuti, ibidem 615-616, 620, 622 y 626-627.

${ }^{5}$ La crítica jamás había estrangulado su condición sacerdotal ni esta, su tarea crítica.. Sylvain LEBLANC (seudónimo de de Bremond), Une oeuvre clandestine d'Henry Bremond. Sylvain Lebrand, Un Clerc qui n'a pas trahi. Alfred Loisy d'après ses mémoires. 1931, Paris, Nourry 1931 IX-102, édition critique et dossier histórique par Émile Poulat, Edizioni di Storia e Letteratura, Roma 1972, 117, 119 y 125. Sobre las relaciones de Loisy-Blondel, H. Bernard-Maître, «Un épisode significatif du modernisme: «Histoire et dogme» de Maurice Blondel d'après les papiers inédits d'Alfred Loisy (1897-1905)», Recherches de Science Religieuse 57 (1969) 49-74. Lagrange sostuvo que Roma tuvo que condenar a Loisy, después de que dijera que la ortodoxia era una quimera. La Iglesia pensaba que su fuerza moral se asentaba en una ortodoxia. Ahora sabe que no puede fiarse de la revelación en la que esta se sostiene. Ahora se transforma en una sociedad laica que predica una moral laica. Cumplido ese programa de moral de la humanidad, dejaría de existir. M.-J. LAGRAnge, Monsieur Loisy et le Modernisme. À propos des «Mémoires» Juvisy, Les Éditions du Cerf 1932, 6-7 y 42-43. 
La doctrina del Vaticano I sobre el Papa fue aprobada con la oposición de una minoría, en la que se hallaba gran parte de los obispos franceses. ¿Se construye la verdad mediante una votación? En el verano de 1892, cuando vuelve a escribir sus reflexiones en su diario, anota el 14 de julio: quiere ser ambicioso y tímido. Necesita soledad. Huye de estar con la gente y, a la vez, quiere influir en los otros, ocupar un buen sitio en el drama que se representa en su época. El tímido impide eso al ambicioso. Lo desalienta. El sabio retiene al insensato. «Au fond, ce doit être l'insensé qui a raison. Il faut bien qu'on se dévoue pour le pauvre prochain. Pour se dévouer, il faut se mettre en avant. Qui perdiderit animam suam salvam faciet eam (Marc, VIII, 35)» ${ }^{6}$. Esa fue su opción, el camino elegido.

Fue superior suyo en Châlons l'abbé Ladot. Cuando el 20 de diciembre 1905 murió siendo cura de Heiltz-le-Maurupt, Ludot no quiso que hubiera un discurso. Loisy dice que sus feligreses y los muchos sacerdotes que acudieron a su funeral fueron las palabras más elocuentes. «Le vraie mot de cette existence n'aurait pas être exprimé ce jour-là... à savoir, que l'Église fait grand gaspillage de nobles vies, de forces intellectuelles et morales qui lui son offertes avec un entier dévouement, mais qu'elle étouffe, étrangle, sacrifie sans scrupule à sa manière à sa chimère d'orthodoxie et aux fantaisies de sa domination». Esta es una de las claves de su pasión en la Iglesia.

Su primer conflicto con las autoridades eclesiásticas fue en 1877. Era seminarista. Vio que su conciencia era muy exigente, pero eso no le impidió hacer concesiones que otros no habrían hecho. Creyó entonces y recordaba luego que jamás se sintió obligado a seguir las vías violentas. Otra experiencia que le confirmaba que podía ser atrevido y tímido, resistente y no ambicioso. Por rectitud, en 1903 y 1904, cuando fueron condenados sus libros se planteó si debía o no seguir en la Iglesia. Luego en 1907-1908, cuando se condenó el modernismo, si debía seguir siendo católico, «tout le reste n'était que bruit et fumée».

En junio de 1884 escribió en su diario: las ideas del siglo XVII no tienen ya sitio en un instituto católico de enseñanza superior. Esa situación creaba contradicciones a personas entonces amigas, como D'Hults y Louis Duchesne, que no las percibían. El problema tenía su causa en la profesión de una ortodoxia dentro de una institución que debe dedicarse a la investigación. No importa el signo de esa ortodoxia. Eso significaba que una universidad no puede ser una universidad «católica», pues no hay una ciencia «católica». De nada se daban cuentan los obispos que tenían la dirección.

En un mundo cerrado, a comienzo de los años ochenta, Loisy halló en la escuela católica liberal una preocupación de la que nacerían veinte años más tarde sus escritos condenados como modernistas.

${ }^{6}$ Mémoires... tome premier 1857-1900, 44, 57 y 211.

Hispania Sacra, LIX

120, julio-diciembre 2007, 633-706, ISSN: 0018-215-X 
Cuando en 1881 suple al profesor de exégesis, Loisy constata que, en la Iglesia católica, no se había iniciado aún el estudio de la Biblia. Era así porque la concepción católica de la verdad bíblica era indefendible y las reivindicaciones de la crítica protestante eran muy justificables. En esa época no había leído libros heterodoxos y conocía el racionalismo bíblico solo en la descripción de quienes lo refutaban. El 8 de marzo de 1882 escribe: debía decidirse entre quienes consideraban la tradición como rutina y los que aceptaban como verdad todo lo que era nuevo. Ninguna de ellas preservaba la fe ni era expresión de la ciencia. «Je me demande si il y a quelqu'un sur la terre pour tenir entre la foi el la science le juste milieu. Celui-là sera mon maître». Pedía a Dios veinte años de salud, de paciencia, de trabajo, «avec cet esprit de discernement, de sincérité, d'humilité, qui permet à la science chrétienne de se produire sans danger pour le savant, à l'édification de l'Église et à la confusion de ses ennemis» ${ }^{7}$.

Se preguntó si no le convenía regresar a su tierra, porque no encontraba respuesta su inquietud por hallar una ciencia que no destruyera la fe. Pensaba que quizás debía abandonar alguna tiempo «cette Babylone où la tête tourne si facilement».

Algunos podrían pensar que Louis Duchesne, también profesor en el Instituto Católico de París, estaba a su lado. Podría haber sido para él un buen guía. Pero lo descartó. No se fiaba de él. Los objetivos que Loisy buscaba en sus trabajos sobre la Biblia no eran los mismos que los de Duchesne en historia de la Iglesia. Según él, Duchesne estaba consagrado al servicio de la ciencia, en cambio, él servía a la Iglesia, a la que se sentía consagrado, por medio de la ciencia. Desde el seminario había intuido lo que era su vocación y su quehacer: más luz en el camino de la fe, para el progreso del bien, por medio de la Iglesia, en la humanidad. Esa era estrella. La seguiría. El solitario estaba aislado.

Cuando estuvo con Guillaume-René Meignan, su obispo, este le avisó que la ciencia arruina la tradición y que la Iglesia no puede vivir sin la tradición. Nunca la Iglesia abandonará las suyas. Deseó a Alfred Loisy que Dios lo guardara en la fe «dans toute sa délicatesse».

Estaba convencido de que el obispo sabía que la ciencia no hincha más que a las mentes cerradas. Sabía también que la crítica histórica aplicada a la Biblia arruina las tradiciones de la Iglesia. Como le pasaba a Duchesne, el personaje siempre presente en este tomo de las Mémoires, Meignan sabía que algunos habían perdido la fe, sin quererlo, por estudiar la Biblia.

\footnotetext{
7 Vid. Antoni BorRàs I Feliu, «Filosofía-teologia en el plateig modernista», Analecta Sacra Tarraconensia XLIV/1 (1974), 170.
} 
En 1883 Loisy, en unas meditaciones, que son plegarias, que, según confiesa, «vient entre les spéculations sur le dogme christologique et les propos relatifs à l'inspiration biblique». Pide a Dios que se alce y le ayude, que, por su nombre, lo libre.

«Il faudrait, je le vois bien, pour être en ce temps-ci votre prophète, commencer par être un saint et devenir un savant. Deux conditions bien lourdes !Mais c'est vrai, o Dieu! Aidez-moi et dissipentur inimici tui!».

«L'Église est à l'heure présente un obstacle au développement intellectuel de l'humanité» Ese hecho no deriva de sus principios ni de su constitución, sino de abusos que pueden cometerse fácilmente. El intento de detener la marcha de la humanidad es tan inútil como el de tratar de que los ríos vuelvan hacia sus fuentes.

La Iglesia no entiende esta situación deplorable, que ella misma se crea. ¿Podría descubrir su error y ponerse a la cabeza del avance de la ciencia? Loisy afirma su fe en que lo conseguirá, porque es una institución divina, salvo que la crisis que padece sea la última, la que precede al final de la humanidad.

$\mathrm{Al}$ día siguiente apunta que la crisis afecta a tres aspectos de su enseñanza. La moral es la que menos ha envejecido. Los dogmas, que la Iglesia juzga absolutos, y su pretensión de tener un estatuto privilegiado se asientan en formas sin curso en la sociedad. Esta y la Iglesia han de reconocer sus limitaciones. La primera pretende que la ciencia le da la clave de todo. No es así. Ante esas «aspiraciones desordenadas» de esta joven ciencia, la Iglesia se inquieta y se desorienta. Le importa que cada uno tenga en regla su conciencia, porque hemos de morir y lo que vale de veras es tener un lugar en paraíso ${ }^{8}$.

En una meditación sobre su vida, recogida en sus cuadernos de 1882-1883, concluye: «Voilà où je suis: toujours convaincu de la nécessité de la religion, de la divinité du christianisme, du rôle bienfaisant qui appartient à l'Église dans tous les siècles...»9 .

En la primavera de 1884 echaron abajo su tesis «De divina scripturaum inspiratione». A diferencia de Renan, que denuncia los errores y contradicciones de la Biblia, Loisy sostenía que estos hechos mostraban la condescendencia de Dios. Esa especie de degración era inevitable y providencial. Por eso juzgaba que la Escritura tenía un puesto eminente en la educación moral de la humani$\operatorname{dad}^{10}$.

\footnotetext{
${ }^{8}$ Diario el 6 y 7 de julio de 1883.

${ }^{9}$ Mémoires..., 47, 54, 58, 71, 81, 102, 109, 136, 138-139.

${ }^{10}$ Alfred LoIsY, ibidem 126-127 y 136.
} 


\section{«L'ESPOIR INQUIET ET TENACE, MAIS L'ESPOIR»11}

Loisy perdió sus creencias religiosas en 1885, a los 28 años. Según Albert Houtin, llegaba así a la misma situación en la que se encuentran los sacerdotes reflexivos y sinceros consigo mismos. Como a otros, les faltó serlo con los demás y con la Iglesia. Debieron abandonarla. Decidieron hacer carrera dentro de ella, pero Loisy no consiguió ser obispo. Justificaron su decisión en el papel social y moral que el catolicismo jugaba. Sus principios, de orden, de entrega, garantizaban la felicidad de la familia y la paz social.

Años más tarde, reanudó su diario. Había dejado de escribir. Y había quemado algunos cuadernos. Ahora anotaba que había muchas pequeñas cosas en las memorias de un hombre grande. Cuando no se es, es bueno mirarse, y lo que se contempla no permite crear un cuadro hermoso. Notaba que, si alguien las hubiera leído, habría notado una gran diferencia entre la vida real y las apariencias. En lugar de una persona tranquila, un alma profundamente inquieta, en lugar de un corazón seco y estrecho, un universo lleno de sentimientos apasionadamente tiernos, en lugar de una vida de estudio colmada sólo en la búsqueda de la verdad, «una existencia atormentada de dudas, de ambiciones y... con todas las decepciones».

Consideraba a Louis Duchesne un «buen profesor de egoísmo». Se preguntaba si tenía afecto a sus alumnos. Se respondía: no, porque hasta ahora eran ellos los que se habían preocupado un poco de él.

Era consciente de las contradicciones ${ }^{12}$. Fue este el rasgo más destacado de su personalidad. Este rasgo, en sus relaciones con los otros, le llevó a pensar siempre contra alguien. Eso lo mantenía despierto y los sostenía. Las obras que combatió con mayor dureza fueron aquellas en las que más se inspiró para las suyas. Su pensamiento no fue muy original, pero supo expresarlo con formas muy personales. Ecléctico, supo elegir bien, tuvo un juicio fino.

Houtin, citando a Sartiaux, dice que supo Loisy rodearse de la aureola de la ciencia y de la persecución. Algunos devotos vieron también la de la santidad.

\footnotetext{
${ }^{11}$ En su lección de clausura del curso en el Instituto Católico, Loisy habló el 16 de junio de 1893 sobre «La question biblique et l'inspiration de l'Écriture». Quiso decir a quienes habían sido hasta entonces sus alumnos, que se sentía unido a ellos en la «Esperanza». Era su última palabra. Aún estaba en la llamada «línea media». Con todo tuvo que enfriar el texto para que pudiera ser soportado por los teólogos. En su discurso, había dicho: «La question biblique ne consiste pas, entendez-le bien, à savoir s'il y a des erreurs dans la Bible, elle consiste à savoir si la Bible contient de vérité», ibidem, 250-253.

${ }^{12}$ De ellas hay que hablar incluso en el terreno intelectual. Siendo apasionadamente crítico, luchando por el derecho a la libertad de quien trabaja en la crítica histórica, se dejó arrastrar por el dogma de su tiempo: la evolución y el progreso sin límite, el dogma de la «perfectibilidad humana», el salto cualitativo en la evolución biológica... Consagrado a una vida de estudio, la vida intelectual, el pensamiento, sólo le interesaba como medios al servicio de un fin moral: la entrega al bien de la humanidad.
} 
Parecía un «confesseur de l'Évangile persecuté par sa sincérité critique». Y concluye: «Je fuis séduit».

Se dio cuenta de que no había alcanzado la gloria que esperaba. Sufrió por eso. El destino no le concedió su favor. No supo gozar de su influencia, de las simpatías que adquiría, de los fervores que despertaba. No supo conservar la entrega que se le ofrecía. «La manque de générosité de l'homme explique profondément les limites de sa oeuvre et de sa pensée» ${ }^{13}$.

¿Es esto justo? ¿Resume su trayectoria? Loisy dijo que «la suerte estaba echada» en 1886, respondiendo a las acusaciones que le hicieron de ser un racionalista. No se había ligado a esas tesis. Las usaba con muchas reservas y como hipótesis. Fue la Biblia la causa primera y principal de su evolución intelectual. Se hizo crítico porque la había leído antes con seriedad. Las demás explicaciones, cuando no eran ficticias, eran irreales. Sólo tienen importancia en la medida en que se unen a la causa principal ${ }^{14}$.

Al elaborar el programa de sus explicaciones en octubre de 1889, Loisy quería estudiar científicamente la Biblia. Había que empezar esto, porque no se hacía en la Iglesia católica. Pensaba que, alargando un poco su significado, podría definir su tarea, empleando el título de la obra de Richard Simon, Histoire critique de la Bible. Su punto de partida, la Biblia como colección de escritos que la Iglesia reconoce inspirados por Dios. Por eso lo primero que debe dilucidarse es la historia de esa noción de «inspiración divina».

Aceptada la inspiración, había que examinar las condiciones en se formó esa colección, la del Antiguo Testamento y la del Nuevo. Era el segundo punto. El tercero, la lengua en que fueron compuestos y traducidos, han llegado a nosotros y las garantías con las que se han transmitido. El cuarto, cuándo, cómo, por quiénes y con qué fin fueron redactados, es decir, la cuestión sobre su autenticidad, La quinta cuestión, qué informaciones pueden obtenerse de ellos sobre la historia de Israel, el cristianismo primitivo, las ideas religiosas de los judíos y

${ }^{13}$ Albert Houtin et Félix SARTiaux, Alfred Loisy. Sa vie, Son oeuvre, manuscrit annoté et publié avec une bibliographie sur Loisy et un index bibliographique par Émile Poulat, Éditions du Centre National de la Recherche Scientifique, Paris, 1960, 45, 56-57 y 291-299. La referencia en la nota anterior, ibidem, 245 y 248-249 Las relaciones de Houtin con Loisy fueron intensas. Luego se deterioraron del todo. Los juicios de otro de sus ex amigos, Paul Sabatier, no dejan a Houtin en buen lugar. Félix Sartiaux publicó Joseph Turmel, prêtre, historien des dogmes, Paris, Rieder 1931.

${ }^{14}$ Alfred Lorsy, Mémoires..., 155. En una carta a Albert Houtim, del 14 de junio de 1919, dice que los filósofos que habían leído sus escritos olvidan que su interés estaba en los hechos religiosos. Por eso nadie debería extrañarse de que no estuviera alineado con los «racionalistas». Cree que la diferencia con ellos es que su idea de la razón y de la ciencia es dinámica y relativa, mientras que esos filósofos, lo admitan o no, hacen de ambas un absoluto y, por tanto una realidad estática. Por eso lo asociaba a veces con Bergson, pero no pensaba que esa afinidad fuera censurable. Mémoires Tome Troisième $1908-1927 \ldots, 380-381$.

Hispania Sacra, LIX

120, julio-diciembre 2007, 633-706, ISSN: 0018-215-X 
de los primeros cristianos, las instituciones religiosas del judaísmo y del cristianismo de los primeros tiempos. La sexta, que podría estar en cuarto lugar, con qué principios los judíos y los cristianismos han interpretado sus libros sagrados. En ese recorrido histórico, pensaba analizar cómo la exégesis científica se ha ido desprendiendo de la exégesis teológica y tradicional, avanzando en su autonomía respecto al método y a las conclusiones.

Cada una de estas seis cuestiones comporta seis historias: la de la inspiración, la del canon, la del texto y sus versiones, la de los escritos bíblicos, la de la religión de Israel y los orígenes del cristianismo y, finalmente, la de la exégesis bíblica.

En el otoño de 1892, hablando de sus publicaciones y tribulaciones, Loisy recuerda su lección de apertura sobre la «Crítique Biblique», que considera «le programme de réforme théologique arrété dans mes méditations» el verano de ese mismo año.

La crítica histórica de la Biblia se funda en la razón. Los teólogos reconocen a la Iglesia un derecho que le permite un control absoluto sobre el trabajo hecho por la crítica. Ese control se ejerce en nombre de la revelación y de la tradición. La conclusión de Loisy: en esas condiciones el trabajo crítico es imposible dentro de la Iglesia.

De ese modo se entiende que sostenga que la crítica no destruye la fe, sino los prejuicios y, actuando así, la ilumina. Pone de manifiesto la pedagogía de Dios, su paciencia, en la educación religiosa de los hombres. La enseñanza de la Iglesia es una columna de luz que guía a sus fieles ${ }^{15}$.

Todo este programa para el curso 1889-1890 lo desarrollaría los años siguientes. Creía que lo que entonces juzgaba arriesgado sería inofensivo unos años más tarde. Esa convicción permite ver qué pensaba del modernismo en $1930^{16}$.

En la primavera de 1892 conoció a Ireland y a O'Connell. El arzobispo salió contento de su conversación con Loisy. El 11 de julio escribió en su cuaderno: hay en la Iglesia gente que siente que se han cortado las alas a su espíritu. El catolicismo trataba de sacudirse la tapa de plomo en que lo había metido la filosofía medieval «et la fausse science des jésuites». Todos ignoran a dónde se va. Nadie dirige el movimiento. Todos temen. «Le spectre de Rome, pétrifié dans sa scholastique et dans sa politique, déconcerte tous les courages».

\footnotetext{
${ }^{15}$ Loisy escribe que no afirmó esto como una coartada oportunista, sino en buena fe y convencido, porque «la colonne de lumière n'était pas pour moi une machine à définitions dogmatiques». Mémoires..., 173-174 y 215-219.

16 «Il n'est pas moins vrai que je préparais inconsciemment une véritable révolution de l'enseignement biblique dans le catholicisme français; et si quelqu'un prétend que le principe du modernisme catholique était déjà là réellement posé, quoique moins largement et ouvertement développé que dans mes écrits de 1900-1903, je n'en disconviendrai pas».
} 
Se pregunta esos mismos días por Dios, que no es un propietario del mundo al que gobierna como señor y arbitrariamente. Dios es el lado interior, eterno, inmutable, simple y uno, del mundo exterior, temporal, cambiante y múltiple. Del Dios que nosotros concebimos con nuestra inteligencia puede decirse que no existe, pero podemos adorar al Dios verdadero, al Dios real, en el silencio de nuestro pensamiento y con espíritu humilde.

Cristo no es un ídolo. La humanidad es criatura de Dios. En cada hombre y en todos ellos hay una lucha para dar a luz una vida moral que es la más divina manifestación del ser. La materia tiende a convertirse en espíritu y éste permanece atraído hacia la materia. De vez en cuando, hay impulsos revolucionarios, sobrenaturales, que elevan a la humanidad por encima de sus preocupaciones vulgares, la redimen. Jesús es el gran iniciador y el mediador de la vida moral, el pontífice eterno.

Se interesaba también entonces por la apologética. Habrá acuerdo entre ciencia y religión, cuando ésta se estudie con un método científico. No será posible proceder de otra manera, porque «la liberté des opinions spéculatives» va unida al desarrollo del espíritu humano. No tolera la reglamentación. Se mantendrán como postulados necesarios sólo la existencia de Dios, el fin moral del universo y Cristo entre estos dos términos ${ }^{17}$.

En los años noventa, en la primera parte de su vida, se consagró Loisy a intentar la reforma de la Iglesia. Erasmo quiso modificar las bases de la vida cristiana. Juzgaba que eso exigía permanecer dentro de la Iglesia. A él le fue posible, pero no lo será para Loisy, porque carecía de relaciones con quienes gozaban de poder decisión en ella. Esa fue la diferencia. Quería Loisy servirla sinceramente. La amaba con un amor exigente, inquieto. Estaba convencido de que el malestar existente entre los intelectuales católicos era un hecho grave, irreversible, porque se fundaba en buenas razones. No podía remediarse sin quitar las causas. La Iglesia era necesaria para la educación religiosa de la humanidad. Ese fue el horizonte y el objetivo de la reforma, la justificación para reclamarla. Guardó, dice Boyer de Sainte-Suzanne, «l'espoir inquiet et tenace, mais l'espoir» de que eso era posible.

Al tener que abandonar sus clases en el Instituto Católico de París comienza una etapa decisiva. Se produce en él un descenso en su fe teológica, pero no deja su vocación, unida a su convicción del valor religioso del cristianismo y de la Iglesia. Pudo dejarla y hacer una carrera universitaria. Pudo permanecer en ella y hacer también una carrera, eligiendo otros asuntos de estudio. Lo hizo así Louis Duchesne.

${ }^{17}$ Alfred Loisy, Mémoires..., 175, 210 y 214.

Hispania Sacra, LIX

120, julio-diciembre 2007, 633-706, ISSN: 0018-215-X 
Quería a la Iglesia. Deseó, en un momento de crisis, ser en ella como el Noé que quiere acoger todo lo que había que salvar. Fue modernista porque era reformador. Antes de que fuera una secularización de las ciencias religiosas, el modernismo fue una vocación sentida por los creyentes desde su fe, no un movimiento de ruptura.

Le importaba a Loisy, como dijo el 18 de marzo de 1935, lo que el modernismo tenía de intento de reforma moral del catolicismo romano, comenzando por lo que era su régimen intelectual, para reconciliar a la Iglesia con la mentalidad de su tiempo, de modo que pudiera ser un agente privilegiado del progreso religioso de la sociedad. Sólo salió de la Iglesia cuando lo excomulgaron por motivos religiosos ${ }^{18}$.

En unas páginas de una alta densidad ética, donde cumplir con el deber es la sola otra recompensa que se espera, Loisy confiesa en agosto de 1892: el universo es la catedral del Dios vivo. En él la muerte es apariencia, porque «tout y est vie: Omnia in ipso vita»19.

Había ingresado un joven conocido suya en el seminario de Châlons. Cree Loisy que en todas las carreras, en todos los caminos que se eligen hay algo de absurdo, en mayor o menor grado. La altura moral del sacerdocio implica necesariamente grandes sacrificios en aras de los prejuicios tradicionales. Por otra parte, el sacerdocio, para mantenerse a la altura que ha alcanzado gracias al catolicismo, debe ser «un ministère de vérité, de sincerité, en sorte que la vie du prêtre est assise sur une contradiction. Toute vie en est là. Il s'agit seulement de faire la juste part de l'inertie et du progrès. Ne rien ébranler, puisqu'on est homme de tradition; tout prévoir et tout préparer, puis qu'on a la responsabilité de l'avenir» 20 .

Semanas más tarde, el 24 de octubre, se entrevistó con Guillaume-René Meignan, antiguo obispo de Châlons, entonces arzobispo de Tours ya con 75 años cumplidos. Hablaron de la situación de la Iglesia en Francia y de la «cuestión bíblica». Meignan le dijo: «Soyons les avocats de la tradition».

El arzobispo veía cercana la supresión del presupuesto de culto. El clero perdería el escaso prestigio que le daba su condición de funcionario. La sociedad no podía vivir sin la Iglesia, pero cada vez pasaba más de ella. Loisy le respondió: «Je crois aussi que l'Église pourrait recouvrer son influence sur la société». La primera condición para conseguirlo entre la gente ilustrada era «une

\footnotetext{
18 Raymond de Boyer de Sainte-Suzanne, Alfred Loisy entre la foi et l'incroyance, Paris, Centurion 1968, 38-39, 48-51. Sobre la excomunión, ibidem, 76-108.

19 Advierte que es una vita muy libre de la que se habla en Jn 1, 3-4.

${ }^{20}$ Alfred Loisy, Mémoires..., 214-215.
} 
refonte plus ou moins profonde de l'enseignement religieux, en commençant pour l'enseignement biblique» 21 .

Al acabar el curso 1892-1893, Loisy dejó el Instituto Católico. Había dado esos años a la institución afecto y trabajo. Tenía la promesa de una capellanía. Era una situación nunca deseada por él. «Si l'on avait pensé me mettre à la porte de l'Institut Catholique, j'étais, en réalité, à la frontière de l'Église». Le repugnaba entonces traspasarla. Ese sentimiento duró varios años ${ }^{22}$. «Mais je venais d'apprendre comment on pourrait me la faire passer».

Ese era su estado de ánimo, según recordaba años más tarde, cuando se entrevistó el 18 de noviembre de 1983 con el cardenal François Richard, arzobispo de París. No se entendieron. Un ejemplo. El arzobispo le dijo que no había datos contradictorios en los evangelios, porque San Agustín los había resuelto $\mathrm{ya}^{23}$. Hasta el 4 de septiembre de 1894 no fue nombrado capellán de las dominicas de Neuilly ${ }^{24}$.

Contaba ya con la amistad de Eudoxe Mignot. Lo conoció en el primer Congreso Científico Internacional de Católicos en París, celebrado del 8 al 13 de abril de 1888, Loisy comentó un texto litúrgico babilónico. Mientras leía su comunicación observó a un clérigo bastante joven aún. Cuando Loisy titubeó si resumir o no su texto, le dijo: lo que nos está diciendo es tan interesante que no se debe abreviar. Era el vicario general de Soissons. Fue nombrado al poco tiempo obispo de Frejus y, luego, arzobispo de Albi. Era «un des hommes qui m'ont été le plus dévoués et que j'ai le plus aimés» 25 .

${ }^{21} \mathrm{Al}$ reproducir esta respuesta, Loisy comenta: «C'est la thèse moderniste, et mgr. Meignan la croit condamnée d'avance. Duchesne pensera de même», Ibidem, 229-230.

22 Aquellos días, cuando tuvo la oportunidad de entrar en la Écoles des Hautes Études, comentó en una carta de Frederich von Hügel, del 24 de noviembre, su repugnancia a trabajar en la enseñanza del Estado. Su lealtad a la Iglesia le hizo juzgar ese paso como si fuera «user des représailles envers l'autorité spirituelle».

${ }^{23}$ Alfred LoISY, ibidem 275 y 291. La cita anterior, ibidem, 298.

${ }^{24}$ Lo comentaba con humor. Mgr. D’Hulst había sido su Rubén. Había aconsejado no «eliminarlo», sino meterlo en una cisterna. Todos los que en la historia no quieren comprometerse, dar la cara por el inocente, han hecho siempre lo mismo. Fue José rescatado por los ismaelitas. Neuilly era su cisterna. «Tant pir si les ismaélites ne passent pas!», ibidem, 357-358.

${ }^{25}$ Hubo un momento de crisis en 1894. Hay huella en una carta del 21 de marzo de ese año, que Loisy califica de «severa hasta la injusticia» y bastante intemperante ibidem 163 y 292-301 y 324-326. En la memorias de Loisy ocupan el capítulo X dos personas: Mignot y Frederich von Hügel. Este, en un momento de crisis religiosa, tuvo la ayuda de l'abbé Huvelin, un sacerdote francés, que jamás pensó en desviarlo del modernismo pese a que murió en 1911, años después de que Pío X lo condenara. Las simpatías de Loisy hacia Huvelin son manifiestas. Frederich von Hügel era un espíritu abierto y muy activo, pese a su débil salud. Fue amigo también de Duchesne, ibidem, 285-292. Vid. L. de LAGGER, «Mgr Mignot et M. Loisy», Revue d'Histoire et de Littératures Ecclésiastiques, 83 (1933) 161-205.

Hispania Sacra, LIX

120, julio-diciembre 2007, 633-706, ISSN: 0018-215-X 
Estos sucesos y la actitud de Loisy ante ellos le ganaron la estima de quienes estaban a favor de una renovación de la Iglesia ${ }^{26}$. Estaba a su lado, sin atrincherarse frente a quienes sostenían otra posición, sin faltar a la equidad, ni siquiera con el cardenal Richard, de quien dependía. Le reconoció moderación y equidad en la defensa que hizo de Felix Klein en la reunión de los obispos protectores del Institut Catholique de París 27.

\section{FE E IGLESIA, ENTRE LA CIENCIA Y LA TEOLOGÍA}

La crise de la foi dans le temps présent. Essais d'histoire et de philosophie religieuses era una serie de ensayos cuyo propósito anunció a Frederich von Hügel en el verano de 1897. Escribió sobre «Régime intellectuel de l'Église catholique». Opina que la exégesis, parada de una manera total en España, despertaba en Italia. En Alemania había mostrado siempre una vitalidad mayor, pero se estaba apagando, cayendo en la ilusión de confundir ciencia con erudición. Había un avance en Francia y en Inglaterra, pero bajo sospecha desde su inicio, por eso no había podido influir en la opinión católica.

Esperaba que todos los conceptos de la religión se entendieran cada día más en un sentido espiritual. La ciencia, en su independencia, no amenazaría, sino que concurriría con otras para la educación de la humanidad. «La théologie et la science, qui ne voudront pas se gourmander, se gouverner ou

\footnotetext{
${ }^{26}$ En el círculo romano que se reunía en via La Sapienza 32, dirigido por Giovanni Genocchi, se le estimaba por su competencia intelectual y por la sinceridad de su conducta. Lorenzo BEDESCHI, «Circoli modernizzanti a Roma, a cavallo del secolo (con alcuni documenti inediti)», Studi Romani 2 (1969) 6-31Citamos por la colección de sus trabajos editada en Fonti e Documenti 15 (1986) 41.

${ }^{27}$ Loisy-Frederich von Hügel, 25 diciembre 1893. Autor de la traducción de la Vie du P. Hecker, lo querían censurar como hereje a quieran Loisy consideraba «le moins héretique des hommes». Comentaba también a Frederich von Hügel noticias sobre la Iglesia en Estados Unidos, citando a Gibbons, Ireland, Meignan, este último un sulpiciano superior del seminario de Baltimore y hombre de confianza de Gibbons, y a O'Connell y Keane. Mémoires..., 482-484 y 490-491 Felix Klein (18621953), profesor de Literatura francesa en el Institut Catolique de París desde 1893, año en que dejó de serlo Loisy. Fue expulsado en 1908 por sus ideas. En 1906 apareció su Découverte de l'ancien monde par un étudiant de Chicago. Paul Sabatier lo consideraba una obra maestra. Aconsejaba que se leyara en voz alta, se discutiera, meditara y se pusiera en práctica. Bedeschi comenta que el duque Tolzi, uno de los personajes, parecía inspirado en Gallarati Scotti. Recuerda que Klein estuvo en la villa de Fogazzaro preparando la conferencia de éste en París. Sobre las «Idee religiose di Giovanni Selva».Vid. Sabatier-Sofia Bisi Albani, 28 noviembre 1906, en «Sabatier e i Lombardi», a cura di Lorenzo Bedeschi, Fonti e Documenti, 3 (1974) 728. En una carta a Gallarati Scotti, 7 diciembre, dice que la novela es «d'un tact et d'un courage admirables», «Garteggio Gallarati Scotti-Sabatier», a cura di Luciano Pazzaglia, ibidem, 816.
} 
se détruire l'une l'autre, n'auront jamais été plus intimement associées, et elles travailleront de concert au bien de note chétive espèce» 28 .

La misión de la Iglesia, recuerda, no es dominar sobre los hombres, sino que se salven por medio de ella. La fe no es la conclusión de un silogismo, es más bien una intuición cierta y oscura, instintiva y voluntaria, respetuosa y confiada, del hecho religioso, que es Dios revelado en la persona de Jesucristo dentro de la Iglesia. Añadía: castigar a alguien que no cree o está equivocado en sus creencias no es encaminarlo hacia la fe, sino proporcionarle argumentos contra ella ${ }^{29}$.

Desde su primera juventud, dijo Mauriac, se planteó las objeciones que debería hacerse un espíritu cultivado ${ }^{30}$. Leyó a Loisy. Lo hizo con una posición previa: quería superar sus dudas. La fe no era para él ni unas creencias ni una Iglesia, sino Alguien, con quien se comunicaba gracias a la Iglesia y a una religión. Esto no es deslumbrante para un filósofo, pero esa fue su experiencia.

«Ha habido siempre en mí, incluso en las horas de mayor turbación y en la más grande oscuridad, un apego, una ternura, es preciso decirlo puesto que es cierto, un amor por todo lo que está atestiguado en cada uno de los versículos sagrados. Y esta pasión, puesto que lo era, trascendía toda certeza racional».

El evangelio de Juan habla de una noche, la de la visita de Nicodemo a Jesús (Jn 3). Nicodemo sabía que la luz es Alguien. «El fuego de una sola noche de Pascal ha bastado para iluminarnos durante toda nuestra vida y, como el niño al que la lamparilla tranquilizaba en la habitación poblada de sombras, por este fuego no temeremos dormirnos» ${ }^{31}$. Lo inefable no se deintifica con lo ausente. Su presencia es más grande que la palabra con la que le damos nombre y lo invocamos.

En la tercera parte La crise de la foi propone la forma en que debe superarse el control que la teología -la del partido romano, debe sobreentenderse- ejercía en la Iglesia. Si el catolicismo continuaba anclado en sus fórmulas y en el senti-

28 Teólogos y científicos se hallaban imbuidos de racionalismo. Mientras esta situación perdure, hay que procurar mantener claras las áreas propias de cada uno. La teología no debería contentarse con la ciencia adquirida, olvidando la ciencia que se está haciendo. Si le sucede eso, morirá. Se quedará momificada.

29 Alfred Loisy, Mémoires... 466 y 472-473.

30 «Para mí que tenía veinte años en aquellos días en que la Iglesia de Francia sufría las consecuencias del asunto Dreyfus, en que los conventos estaban vacíos en nombre de la ley, en que la encíclica «Pascendi» parecía prohibir al estudiante que yo era todo contacto con el pensamiento moderno, doy testimonio de ello ahora, fue el Cristo de Pascal quien me dijo, en aquellas horas: «Permanece conmigo».

${ }^{31}$ François Mauriac, Lo que yo creo, Madrid, Taurus 1962, 12-14 y 23-25, 36 y 95. El texto citado en la nota anterior, ibidem, 88 .

Hispania Sacra, LIX

120, julio-diciembre 2007, 633-706, ISSN: 0018-215-X 
do material de estas, en todas sus instituciones tal y como subsisten, si se somete a un ideal cerrado, temporal, tal como lo era la sociedad cristiana de la edad media -el medievalismo denunciado por George Tyrrell-, tiene sus días contados. Su final dependerá del vigor con el que la sociedad esté decidida a seguir su propio camino y a sacudir el yugo de quienes se oponen al progreso ${ }^{32}$.

La tensión tradición-progreso, mantener el pasado y asumir la responsabilidad del futuro, fue para Loisy un ministerio de sinceridad y de verdad. Estos años vivió obsesionado con Pierre Batiffol, rector del Instituto Católico de París. Cuando Louis Duchesne fue incluido entre los colaboradores de la Revue d'Histoire et Littérature religieuses, editada por el Instituto Católico de Toulouse, explicó a Loisy en una carta del 25 de febrero de 1898 que lo había aceptado con la condición de que Batiffol dejara de pincharles a él y a Loisy. Años más tarde, cuando apareció el libro de Jean Rivière ${ }^{33}$, en una nota escrita el 19 de diciembre de 1929, Loisy recuerda que entonces Duchesne estaba convencido de que no era posible reconciliarse con el rector del Instituto Católico ${ }^{34}$.

En las pruebas, eligió el deber, obedecer a su conciencia. Cuando el cardenal François Richard condenó su artículo «La Religion d'Israel», aparecido en la Revue du Clergé Français, 15 de octubre de 1900, Loisy creyó que debía renunciar a la pensión que le pasaba el arzobispo. Lo hizo. Guardó silencio, porque «je ne voudrais pas, quant à présent, augmenter par une justification publique l'émotion que ce jugement pourra produire». No le pasó siquiera por la cabeza la idea de someterse a la condena eclesiástica. El procedimiento le había irritado. Pensaba romper esa especie de lazo que lo unía con el arzobispado. Ni el cardenal ni nadie de la curia le comentó ese paso ${ }^{35}$.

Perdía una parte de sus ingresos. Por medio de Paul Desjardins trató de hallar un puesto. Sabía las consecuencias de ese paso a la École des Hautes Études. Para él era acogerse a un asilo, pues ningún poder del mundo podría imponerle la obligación de morir de hambre o de no tener qué hacer. Quería volver a ser profesor. Le parecía un sueño tres semanas antes. Aspiraba a proseguir sus

\footnotetext{
32 «Mais le catholicisme est tout autre chose que ce formidable crampon dont ses adversaires se font un épouvantail et quelques-uns des nôtres voudraient nous faire admirer», Mémoires pour servir à l'histoire religieuse de notre temps..., 470.

${ }^{33}$ Le modernisme dans l'Église, Paris. Libraire Latouzey et Ainé. 1929. Rivière era profesor en la facultad de teología de Strasbourg. Fue el discípulo preferido de Batiffol. Este libro fue la primera historia del modernismo. Es muy hostil a los modernistas.

${ }^{34}$ Añadía en nota, «ce personnage, dont l'insincérité m’inspire la plus vive répugnance. Sa littérature ne contient pas une idée; il a l'érudition des autres, le style assez alerte quand il ne singe pas les Allemands». Loisy aclara que para Duchesne, «insincérité» significaba «orthodoxie tapageuse»Mémoires..., 487.

35 Frederich von Hügel reconoció que Loisy había actuado con dignidad, porque era más sabio renunciar que esperar a que dejaran de entregársela. Alfred Loisy, ibidem, 575-577.
} 
trabajos en condiciones modestas. Nada más que eso. La medida del cardenal era brutal. Lo difamó y redujo a la mitad sus ingresos. En los últimos veintiún años había tenido que rehacer su carrera cinco veces. No podría hacerlo otra vez. No se lo consentían su edad y su salud. Había vivido precariamente, pero ahora no, «tant que cela dépendra de moi, je ne laisserai pas à ceux qui me poursuivent la joie de leurs victoires imbéciles».

Esta decisión se reforzó seis meses después. Nadie podía introducir algo de luz en los «espíritus teológico-político-eclesiásticos», en cuyas manos estaba la solución de su caso. Sentía que había un terror generalizado ${ }^{36}$.

Estuvo Frederich von Hügel en noviembre de 1901 con el P. Alberto Lepidi, el dominico, teólogo del Papa. Confesó Loisy a su amigo que se le pedía un suicidio intelectual, cerrando los ojos a la evidencia. Su única salida era mentir para salvar su situación y asegurarse en la Iglesia una situación respetable, pero eso sería inmoral. Le quedaba únicamente resignarse al aislamiento y a la persecución, y hablar según su conciencia. Estaba persuadido de que, si el interés de la Iglesia reclama que no se escandalice al ignorante, exige «non moins impérieussenent qu'on ne scandaklise pas l'intelligence et la science».

No podía, pues, atender el consejo de Lepidi: ir a Roma. Expuso a Lucien Lacroix y a von Hügel estas cuatro razones. Una, su salud no le consentía el esfuerzo físico e intelectual que le suponía cambiar de plan de vida y mantener conversaciones con teólogo. Dos, no iría a disculparse, porque no se sentía culpable ni pediría jamás como un favor que no le condenaran. Tres, era un paso inútil. Hechas las concesiones para evitar una censura, quedaría desarmado y lo condenarían. Cuatro, nada le importaba, pues su porvenir y su estima habían quedado ya profundamente afectados. No lo serían más. No sabía aún si elegía la posición de Richard o la de Mignot ${ }^{37}$.

\section{EXÉGESIS Y DESCUBRIMIENTOS Y PROGRESOS DE LA CIENCIA}

En 1881 apareció en Madrid La Biblia y la Ciencia, del dominicio Ceferino González ${ }^{38}$. El prólogo, reproducido luego por el P. J.-M. Lagrange como pro-

${ }^{36}$ Loisy agradecía la carta de Mignot al Papa, aunque temía que sería inútil. Loisy-Mignot, 11 noviembre 1900 y 13 mayo 1901, en Louis-Pierre SARDELLA, Mgr. Eudoxe Irénée Mignot (1842-1918). Un évêque français au temps du modernisme, Paris, Cerf 2004, 343 y 347,

37 LOISY-VON HÜGEL, 25 noviembre 1901, Mémoires pour servir à l'histoire religieuse de notre temps, tome II (1900-1908), Paris, Émile Nourry 1931, 72 y 74.

38 Vid. Eduardo Solís Fernández, «La Biblia y la Ciencia» del Cardenal Zeferino González: un esfuerzo por hacer razonable la fe», Studium Ovetense: Revista del Instituto Superior de Estudios Teológicos del Seminario Metropolitano de Oviedo, 22 (1994), 205-224.

Hispania Sacra, LIX

120, julio-diciembre 2007, 633-706, ISSN: 0018-215-X 
grama de la Revue Biblique en 1892, fue calificado por el exegeta dominico como una ruptura con la rutina «obstinadamente cerrada en sus trincheras» 39 . Este texto, según confesó Lagrange, contaba con la aprobación de León XIII.

La posición del cardenal español se resume en estas afirmaciones:

1. Certeza de que es imposible un conflicto entre la Biblia y la ciencia. Porque un escritor cristiano no debe perder la serenidad, sino lanzar su mirada inquisitiva en todas las direcciones. Tiene derecho a marchar hacia la verdad «por medio de la observación y del trabajo experimental». La Iglesia nada tiene que temer, sino mucho que esperar de la ciencia, cuando esta es imparcial_y no se pone al servicio de intereses ajenos a ella. Nadie debe confundir la exégesis con la verdad, pues es sólo una investigación de la verdad. En eso se asimila a las otras ciencias.

2. Cuando se presenta el conflicto, hay que dudar de los datos de la ciencia o de la interpretación exegética. La ciencia no puede estar en contra de la verdad religiosa. La contradicción puede hallarse en la ciencia o en la teología. Por eso hay que examinar ambas antes de concluir que una verdad establecida por la teología niega el resultado de una investigación y que este se opone a una verdad de la teología. Los avances de la ciencia y de la teología han mostrado ya que la contradicción que parecía surgir en un momento quedaba superada luego ${ }^{40}$. Con todo, las adquisiciones de las ciencias naturales y físicas, de la biología... exigían la conveniencia y hasta la necesidad de modificaciones profundas en el sentido y alcance que los $\mathrm{Pa}$ dres de la Iglesia y los exegetas de otros tiempos daban a os textos bíblicos.

3. Hay que distinguir entre la interpretación auténtica de la Iglesia y las interpretaciones variables de unos autores. Es un deber acomodarse a esa diferencia.

4. Toda la Biblia está bajo la inspiración de Dios. Y aquello que afirma no puede contener error $\mathrm{y}$

5. Es una necesidad para los exegetas católicos seguir el desarrollo de las ciencias que afectan al conocimiento de la Biblia. Es un deber «indagar si esos conocimientos de los que la ciencia y el hombre justamente se enorgullecen en nuestros días contradicen la verdad revelada». Y es también un deber revisar afirmaciones hechas por la exégesis para ver si, en presencia de los descubrimientos y progresos de la ciencia, pueden continuar sosteniéndose ${ }^{41}$.

39 J.-M. Lagrange, «Avant-Propos», Revue Biblique 1 (1892), 11-16

${ }^{40}$ Hablando de la historia, Zeferino González dice que la investigación sobre los pueblos antiguos de Oriente «ha venido a descubrir en nuestros días datos y elementos que, si por un lado afirman y corroboran la verdad y exactitud de los libros sagrados, por otro modifican el sentido y alcance que solía darse antes a algunos textos relacionados con la edad de algunos imperios y naciones».

41 Vid. la introducción de Salvador MuÑoz IgLesias Doctrina Pontificia. I Documentos Bíblicos, Madrid, Editorial Católica, BAC 1955, 45-48. V. LARRAÑAGA, «El cardenal Ceferino González y Su Santidad León XIII frente al problema bíblico de su siglo», Estudios Bíblicos 7 (1948), 77-114. 
La posición protestante sobre el libre examen en la interpretación de la Escritura evolucionó hacia posturas más radicales. La crítica de la filosofía kantiana al conocimiento objetivo se extendió al plano religioso. No existía una religión positiva, es decir revelada e impuesta normativamente al hombre. La fe era una experiencia individual y la religión, una forma de expresarla. Los dogmas son los símbolos con los cuales se comunica esa experiencia, no son fórmulas que fijan una doctrina. La Escritura no es palabra de Dios, sino un testimonio escrito de la revelación divina. Siendo obra humana, el texto está sometido a error. La Biblia se transforma para los críticos no es una revelación, sino construcciones dogmáticas de unos hombres. La revelación es un mito. Es imposible como hecho.

En los años sesenta del siglo XIX aparece el protestantismo liberal que se prolonga hasta la I Guerra Mundial. Su figura central, A. Harnack. En 1872 se publicó el relato babilónico sobre el diluvio. Y dos años más tarde, J. Wellhausen expone su teoría sobre el Pentateuco, que implica una profunda revisión de la idea sobre la religión de Israel. En la década siguiente aparecen una serie de publicaciones y se va a una sistematización de los halazgos hechos. En 1886 empieza Emil Schürer la publicación de su Geschichte des Jüdeischen Volkes in Zeitsalter Jesu Christit2. E. Renan había culminado en 1883 la edición de su obra Histoire des origines chrétiennes.

El P. Lagrange fundó L' École Biblique de Jerusalén en 1891. Al año siguiente, aparece la Revue Biblique. Inician sus excavaciones en ese tiempo la Palestine Exploration Found y la Deutscher Palästina Verein. Los descubrimientos permiten un conocimiento mayor del mundo en que se sitúan los relatos y los personajes del Antiguo Testamento.

1902 sería un año decisivo. En enero se habló de Félix Klein y de Alfred Loisy como candidatos para la sede de Mónaco. Se consideraba a Klein la encarnación del americanismo, cuando este no existía ya en América. La objeción contra él era absurda, porque se le atribuía una herejía que no existía. Duchesne comentaba que Klein se la inventó deliberadamente en su introducción a la Vie du P. Hecker. Cuado la Testem Benevolentiae, de León XIII, la condenó Klein se adhirió y retiró la obra «en toute candeur et simplicité».

Loisy comentó también en enero de 1902, el plan de estudios de su seminario, aprobado por el obispo de La Rochelle, Le Camus ${ }^{43}$. Le hacía tres observaciones. El programa era muy ambicioso. Iba más allá de lo que podía darse en un seminario. Pedía a los profesores un esfuerzo imposible sumía la grave res-

\footnotetext{
${ }^{42}$ La edición de Leipzig, J. C. Hinrichs 1886-1890, 2 vol.

${ }^{43}$ Sobre el obispo, vid. Yves Blomme, Émile Le Camus (1830-1906). Son rôle au début de la crise moderniste et lors de la Séparation de l'Église et de l'État, Paris, L'Harmattan 2002.

Hispania Sacra, LIX

120, julio-diciembre 2007, 633-706, ISSN: 0018-215-X
} 
ponsabilidad de que los seminaristas descubrieran cosas inesperadas para el obispo ${ }^{44}$.

Cuando en abril de 1902 se comenzó a hablar de la Pontificia Comisión Bíbli$\mathrm{ca}^{45}$. Sus miembros eran los mejores, si se descartaba a quienes quedaron excluidos por no ser bien vistos en Roma ${ }^{46}$. Había que responder a una situación nueva.

En otoño apareció L'Évangile et l'Église ${ }^{47}$. Era su réplica a Adolf Harnack ${ }^{48}$. En la controversia Loisy-Harnack ha señalado Boschini que hay algo más que diferencias entre dos personas y las iglesias a las que cada uno pertenece. «Sono piuttosto l'espressione consapevole di due differenti filosofie della conoscenza scientifica e della storia»49.

En 1902 Adolf vom Harnack publicó en Tübingen su Mission und Ausbreitung des Christentums in den ersten drei Jahrhunderten. La última versión, aparecida en 1924 fue traducida al francés ${ }^{50}$. Una de sus tesis es que el cristianismo se difunde rápidamente gracias a su sincretismo, porque supo integrar símbolos, relatos, mitos y ritos del mundo pagano.

Harnack expone la labor misionera y caritativa del cristianismo, su moral, su doctrina, verificando esa tesis. Los métodos misioneros y catequéticos y el carácter pagano de los nombres cristianos es otro argumento a favor la teoría del sincretismo.

44 Creía que Le Camus era poco fiable, un meridional muy abierto de palabra, pero «tout à fait, un marseillais, bien qu'il soit de Carcassonne» Alfred LoIsY, Mémoires pour servir à l'histoire religieuse de notre temps II, Paris, Émile Nourry 1931, 94-95 y 100.

45 Establecida por León XIII, con la carta apostólica Vigilantiae studiique, del 30 de octubre de 1902, Acta Sanctae Sedis 35 (1902-1903), 234-238. se le encomendaban estas tres funciones: promover eficazmente entre los católicos el estudio bíblico; contrastar con los medios científicos las opiniones erradas en materia de Sagrada Escritura; estudiar y iluminar las cuestiones debatidas y los problemas que fueran surgiendo en la investigación bíblica.

46 Rampolla fue presidente de a Comisión Bíblica. En el ambiente en que se preparaba la Pascendi, el 30 de abril de 1907, en su carta a Hildebrand Hemptinne, abad primado de los benedictinos, recordaba el objetivo de la Comisión creada por León XIII: proporcionar normas claras y seguras que, apreciando las conquistas de la ciencia, permitan preservar la tradición de la Iglesia y dar «nuevo impulso a los estudios bíblicos, más que nunca tal vez importantes en estos tiempos tan atormentados por la duda universal y por el evolucionismo racionalista». Doctrina pontificia. I Documentos Bíblicos, edición preparada por Salvador Muñoz Iglesias, Madrid, Editorial Católica, BAC 1955, 277.

${ }_{47}$ Noticia sobre las ediciones de L'Évangile et l'Église, Lorenzo BEDESCHI, «Saggio Introductivo a Il Vangelo e la Chiesa - In torno a un piccolo libro», Fonti e Documenti 15 (1986) 90.

48 Una reciente introducción, Ernst DASSMANN, «El Lerhbuch der Dogmengeschichte y Das Wesem des Christentums de Adolf von Harnack», Anuario de Historia de la Iglesia XIII (2004) 179-198.

49 Paolo BoschINI, «Harnack e Troeltsch intepreti del modernismo», Il modernismo tra cristianità e secolarizzazione. Bilanci e prospettive, Atti del Convegno internazionale di studi storici, tenutosi ad Urbino dal $1^{\circ}$ al 4 ottobre 1997, a cura de Alfonso Botti e Rocco Cerrato, Urbino, Quatroventi 2000, 345.

${ }^{50}$ Mission et expansion du christianisme dans les trois prémiers siècles, Paris, Editions du Cerf 2004, 796. Hay una traducción italiana posterior, Missione e propagazione del Cristianesimo nei primi secoli, Cosenza 1986. 
El cristianismo penetró en todas las clases sociales. Harnack estudia la aparición de las herejías, deteniéndose especialmente en las que mejor conoce la de Marción y el gnosticismo.

La idea de L'Évangile et l'Église la comentó Loisy el 18 de mayo de 1902 a von Hügel. Harnack sostenía que la idea base del Evangelio era la paternidad de Dios y la conciencia filial de Jesús. Loisy quería demostrar que esa idea no ofrecía mejores garantías históricas que el Evangelio de Juan. Eso significaba que el neo-protestantismo se aproximaba al catolicismo porque la base de su sistema era la tradición

Estaba en esos momentos obsesionado por su libro sobre los sinópticos. Sabía que su polémica con Harnack le quitaría tiempo. Con todo dos meses más tarde tenía el manuscrito listo para la imprenta. Hacia el 15 de agosto lo envió a Mignot, que le pidió que retrasara la edición. El 17 de septiembre el arzobispo, leído el texto, lo juzgó lo más completo y objetivo escrito por Loisy. Comprendió el sentido y el alcance de lo que en él se decía: una exposición histórica del desarrollo del cristianismo, de la que se deducían algunas conclusiones favorables al catolicismo ${ }^{51}$.

Enseguida, dejando a un lado su trabajo sobre los sinópicos, se puso a corregir pruebas de L'Évangile et l'Église y de sus Études Évangéliques, que deseaba que salieran a la vez ${ }^{52}$. Estaba agotado, escribió a von Hügel el 28 de septiembre ${ }^{53}$. En el nuevo libro se recogían las ideas de «Firmin» sobre el reino de los cielos, el Hijo de Dios, la jerarquía eclesiástica, el dogma cristiano y el culto católico ${ }^{54}$.

Estas semanas su trabajo como escritor estuvo marcado por la cuestión de Marcel Hebert ${ }^{55}$ y por su candidatura al episcopado. Mignot le escribió el 25 de octubre que quizás hubieras ido mejor retrasar la publicación, pero cambió de idea $^{56}$.

${ }^{51}$ Alfred Loisy, Mémoires..., tome II..., 120-140

52 En una carta al cardenal Mathieu, 27 de octubre de 1902, decía que los dos libros tenían en común ser un ensayo de reconstrucción histórica del Evangelio y de los orígenes cristianos desde el punto de vista católico, ibidem, 144-145.

${ }^{53}$ Además del esfuerzo físico e intelectual, estaba preocupado por los efectos de sus dos libros, ibidem, 149.

${ }^{54}$ Después de la condena de sus cinco libros dejó de usar el seudónonimo «Firmin». Desmintió a Alfred Baudrillart, que le atruía haber usado y seguir usando muchos. Por su prosa bastaba para descubrirlo. Es un dato para descubrir que la etapa de lucha con la autoridad eclesiástica había acabdo para él. Alfred Loisy, Mémoires..., tome II..., 531.

55 Noticias sobre él en julio 1901, Ibidem. 49-50.

${ }^{56}$ El 10 de noviembre escribió a Loisy que el libro, «malgré les inévitables oppositions qu'il va rencontrer, vous fera le plus grand bien en ce moment, surtout si l'on a l'équité de tenir compte des observations et réserves que vous présentez dans la préface», ibidem, 156.

Hispania Sacra, LIX

120, julio-diciembre 2007, 633-706, ISSN: 0018-215-X 
Deseaba que L'Évangile et l'Église y sus Études Évangéliques salieran a la vez. En una carta al cardenal Mathieu, 27 de octubre de 1902, decía que los dos libros tenían en común ser un ensayo de reconstrucción histórica del Evangelio y de los orígenes cristianos desde el punto de vista católico. Los dos libros eran una reconstrucción histórica del Evangelio y de los orígenes del cristianismo. Su objetivo, anotaba en su cuaderno el 13 de octubre, era «adapter le catholicisme théorique aux faits de l'histoire, et le catholicisme pratique aux réalités de la vie contemporaine» .

El texto de Loisy, era una versión alternativa lo que Harnack sostenía ${ }^{57}$. Sacaba el problema de la perspectiva racionalista y los situaba en el campo histórico: cómo fue y evolucionó el movimiento iniciado por Jesús. Eso significaba dar contexto a la obra de Jesús, a los testimonios sobre ella y a la evolución que fue experimentando. Esta perspectiva fue acogida con moderada benevolencia gracias a que acababa de crearse la Comisión Bíblica esos mismos días. Las cosas cambiaron enseguida. Intervino el nuncio Lorenzelli58, que pidió a los cardenales Richard y Perraud que una comisión teológica lo censurara ${ }^{59}$.

Duchesne comenta con cierta amargura y algo de humor la conclusión a la que había llegado tras la lectura de L'Évangile et l'Église. Había tenido en sus manos el ejemplar del cardenal Mathieu. Se alegraba de que no hubiera leído los dos primeros capítulos, los de mayor calado. Tenía suerte Loisy de que no lo entendieran. Debía alegrarse porque eso le salvaba de correr la misma surte que Giordano Bruno ${ }^{60}$.

Cuando apareció su respuesta ${ }^{61}$, Duchesne recordó que se necesitaba tiempo para que pudiera ser aceptable esa exégesis. Creía que el catolicismo no era incompatible con la crítica tal como la entendía Loisy, pero no pensaba que sus resultados pudieran ser aceptables para la mayoría de los católicos, incluidos obispos y cardenales ${ }^{62}$.

57 Das Wesen des Christentums, 1900. Era el texto de las dieciséis conferencias pronunciadas por Adolf Harnack ante los estudiantes en la Universidad de Berlín en 1899 y 1900. En diez años tuvo setenta ediciones.

58 Nombrado arzobispo de Lucca fue un personaje influyente. Su actitud autoritaria le impidió ser un arzobispo querido por su clero. G. BIANCHI, «Il Card Benedetto Lorenzelli, nuncio apostolico a Parigi e arcivescovo di Lucca, La Provincia di Lucca, XI/2 (1971), 71-86.

${ }^{59}$ Lorenzo BEDESCHI, «Saggio introduttivo a A. Loisy, Il Vangelo e la Chiesa..., 92 y 104-109.

${ }^{60}$ Mathieu le había dicho que Loisy había sido presentado en una terna para obispo de Monaco. Sus otros dos compañeros también eran sospechosos para la Santa Sede. Carta a Loisy, Roma, 11 noviembre 1902, en Bruno NEVEu, «Lettres de Monseigneur Duchesne, directeur de l'École Française de Rome à Alfred Loisy (1896-1917) et a Friedrich von Hügel (1895-1920)», Mélanges de l'École Française de Rome. Moyen âge, Temps Modernes 84 (1972), 295-296.

${ }^{61}$ Autour d'un petit livre, Loisy puso en la dedicatoria del ejemplar enviado a Duchesne, «Et eris novissimus... peior priore».

${ }^{62}$ Este mismo escepticismo lo mantenía respecto a la obra de Harnack, a psar de que este le dijo que el mundo protestante alemán estaba preparado para ello. Carta a Loisy, 26 octubre 1903, ibidem, 498. 
En medio de la crisis del otoño de 1902, cuando apareció L'Évangile e l'Église, Loisy escribe en tono airado sobre aquellos a quienes califica como «imbéciles, lâches, menteurs». Había que aplastarlos como gusanos. Le habían impresionados las cartas de un dominico de Fribourg y de un lazarista profesor en un seminario mayor, que habían sido tratados mal por sus propios institutos religiosos. El 17 de noviembre creía que el único camino, tal como lo había visto ya en sus ensayos escritos en Neuilly y no publicados, era un cambio de mentalidad, de espíritu. Eso suponía respetar la conciencia y las ideas del otro, convencerse de que los procedimientos deshonestos, incluso si estuvieran justificados en asuntos seculares, no lo estaban como medios para defender la verdad divina. En cuanto a los hechos, era un deber respetar la legitimidad de una labor de crítica histórica, que debería ser independiente y no sometida al control de la teología 63 .

Expuso Loisy al cardenal Mathieu su posición en relación con su trabajo. Le afectaba sobre todo la mención al P. Vigouroux. En Roma era considerado una persona «rassurant». Quería dejar claro, ante su posible protector en la curia romana, que jamás se había interesado por crear seguridades. Se conformaba con ser honesto. Eso le obligaba a ser leal a la Iglesia y a La Sorbonne, las instituciones a las que en esos momentos servía,

Su razón para actuar así era que la grave situación del catolicismo, para respetarse y ser respetado, exigía a un sabio o a un apologista, cuando expusiera sus conclusiones, no subordinar a su interés personal la sinceridad. «La manque de sincérité qui caractérise l'apologétique douée de l'imprimatur est justement ce qui révolte les esprits cultivés» ${ }^{64}$.

El 3 de enero de 1903, en una carta a von Hügel, habla de las dos áreas de trabajo. Una, exclusivamente científica, representada por su Mythes Babliloniennes y por su estudio sobre San Juan, inédito en aquella fecha. La otra, era un esfuerzo por conducir a un sentido aceptable los derechos y las pretensiones de la Iglesia. En ese momento sentía que esta segunda tarea era ineficaz. Por eso iba a consagrarse exclusivamente a la primera ${ }^{65}$.

Se defendió Loisy en Autour d'un petit livre, publicado en octubre de $1903^{66}$. Era un libro que se leía con interés. Su refutación de Harnack estaba hecha desde la izquierda.

\footnotetext{
${ }^{63}$ Alfred Loisy, Mémoires..., tome II, 158-159.

${ }^{64}$ Ibidem, 164.

${ }^{65}$ Ibidem, 144-145 149 y 182.

${ }^{66}$ En esta obra hay cartas a los obispos de Autun, cardenal Perraud, de La Rochelle y al arzobispo de Albi, Mignot.

Hispania Sacra, LIX

120, julio-diciembre 2007, 633-706, ISSN: 0018-215-X
} 
La situación era nueva. Había mucho interés por el cristianismo ${ }^{67}$. Harnack, Tyrrell, Loisy, Herbert, Francesco Nobili Vitelleschi... y una larga lista de neo-gnósticos estaban preocupados por preservar su condición de cristianos, pero se empeñaban en colocar bajo esta etiqueta ideas que no eran conciliables con ella. ¿Era viable su propósito? ¿Podrían esperar que la Iglesia católica aceptara una exégesis tan atrevida de su dogma y de su Biblia?

Erraban. El cristianismo que cuenta como religión es el que preside el Papa, el que practican gentes sin inquietud científica. Fuera de eso, «il n'y a que des vapeurs légères» 68 .

Sus adversarios preparaban una lista de 33 proposiciones, sacadas de sus escritos. El cardenal de París las envió al Santo Oficio, que, en diciembre de este año ponía en el Índice de Libros Prohibidos cuatro obras de Loisy ${ }^{69}$. La iniciativa del arzobispo de París y la formación de una comisión con los cardenales Rampolla, Vives y Tutó y Steinhuber fueron los precedentes de las decisiones que se tmarán en 190770 .

Denunció Loisy a quienes no querían o no podían imaginarse el presente y el futuro del catolicismo sino como la forma inmóvil y convencional de un pasado que jamás existió. Imaginaban que, al celebrar los funerales de la vieja exégesis, se llevaba a la tumba a Cristo y a su Evangelio, la Iglesia y su autoridad, el dogma y su verdad, toda la teología, con los sacramentos y todo el culto católico.

Lejos de ser una obra de escepticismo o de muerte, L'Évangile et l'Église era una obra de esperanza y de vida. Apenas echaba una mirada hacia aquello que desaparecía: la falsa apologética, las vidas de Nuestro Señor, que no son historias de Jesús, la Iglesia política, la superstición de la fórmula, el mecanismo ritualista. Su escrito era, pese a la aridez de su estilo didáctico, un homenaje a Cristo-Dios y a la Iglesia cuerpo viviente del Cristo inmortal11.

67 «Je suis frappé de voir tan de gens, de tant manières sans doutem mais avec la même prodigieuse desinvolture, les honneurs du christianisme».

${ }^{68}$ Duchesne-von Hügel, 28 noviembre 1902, en Bruno NEvEU, «Lettres de monseigneur Duchesne à Alfred Loisy (1896-1917) et à Friedrich von Hügel (1895-1920)»..., 592. Volvió sobre este mismo asunto cuatro años más tarde. Ponía el ejemplo de Herbert. Era impensable esperar que la Iglesia aceparía esa exégesis del evangelio y de su doctrina, Carta del 8 junio 1906, ibidem, 594.

${ }^{69}$ L'Évangile et l'Église, Autour d'un petit livre, Études Évangeliques y Le quatrième Évangile.

${ }^{70}$ Rampolla fue presidente de a Comisión Bíblica. En el ambiente en que se preparaba la Pascendi, el 30 de abril de 1907, en su carta a Hildebrand Hemptinne, abad primado de los benedictinos, recordaba el objetivo de la Comisión creada por León XIII: proporcionar normas claras y seguras que, apreciando las conquistas de la ciencia, permitan preservar la tradición de la Iglesia y dar «nuevo impulso a los estudios bíblicos, más que nunca tal vez importantes en estos tiempos tan atormentados por la duda universal y por el evolucionismo racionalista». Doctrina pontificia. I Documentos Bíblicos..., 277.

${ }^{71}$ Autour d'un petit livre, 20-22. 
En un capítulo inédito de L'Évangile et l'Église, Loisy fija las relaciones entre historia y teología en tres postulados:

1. Teológico: las ideas religiosas fundamentales, empezando por la de Dios, han sido invariables, al menos en una parte escogida de la humanidad, desde el origen del mundo hasta hoy;

2. Mesiánico: Jesús y la Iglesia han sido objeto de las predicciones formales y claras del Antiguo Testamento;

3. Eclesiástico: la Iglesia en los grados fundamentales de su jerarquía, en sus dogmas fundamentales y en sus sacramentos ha sido creación directa de Cristo

«Or ces trois postulats, sur lesquels repose tout l'édifice de la croyance catholique, ne sont pas seulement indémontrables, ils sont démontrés faux par l'histoire» ${ }^{72}$.

En la distancia, recogió Loisy en 1931 la acusación de quienes decían que L'Évangile et l'Église y sus Études Évangéliques eran dos escritos innecesarios. Nadie los reclamaba. En eso también era modernista, porque el modernismo, como dijo luego Benedicto XV y otros eclesiásticos, fue una aventura sin sentido, que no hizo más que plantear problemas innecesarios.

L'Évangile et l'Église era un escrito apologético y reformador. Recogía tres asuntos: el modo de entender la divinidad de Jesús, la autoridad de la Iglesia y la acción de Dios en los sacramentos. La primera y la tercera, pese a las pretensiones de la teología, no pueden definirse. Hay que limitarse a analogías que la hagan inteligible. Estaba convencido de que la razón humana sólo alcanzaba lo externo, pero añadía, «nous sommes conduits, avec tout le reste, par une puissance que ne nous dit pas son sécret».

Frederich von Hügel le felicitaba el 15 de noviembre, cinco días más tarde que el arzobispo de Albi, su otro gran amigo. Este «anti-Harnack» era una pieza de gran valor, la más bella y la más a propósito para modificar la forma de presentar, de concebir el catolicismo «par l'Église officielle ellemême» ${ }^{73}$.

¿Qué sentia Loisy esos días? Anotó en su diario el 13 de noviembrede 1902. Había paseado con Klein y con un ***. Los dos eran teólogos. Creían que Jesús era un pequeño personaje histórico, que no admitía comparación

72 Emile Poulat, Histoire, dogme et critique dans la crise moderniste, Tournai, Casterman 1962, $117-124$ y 515 .

${ }^{73}$ Esa tendencia a sentirse perseguidos, bajo amenaza, aparece en este mismo texto: sería muy difícil condenar el libro, porque era la única respuesta eficaz a Harnack, et ses messieurs son de même plus hommes d'affaires qu'ils ne sont étroits», ibidem, 157.

Hispania Sacra, LIX

120, julio-diciembre 2007, 633-706, ISSN: 0018-215-X 
con Sócrates. Reacción de Loisy: la afirmación era «une ineptie profonde». El más pequeño grano de bondad tiene más valor que la más alta filosofía. Por eso Jesús, como salvador, desafía a todos los Sócrates, «même appuyés par tous les efforts de l'économie sociale». Esta era la compañía que le daban sus amigos.

En el otro lado, tensando su espíritu, lo que le venía preocupando desde que fue enviado a Neuilly: la necesidad de cambiar la forma de tratar a las personas y las cuestiones. Para las primeras, respetar el pensamiento y la conciencia del otro. Había que persuadirse que los procedimientos deshonestos entre las personas del mundo y para defensa de las opiniones de orden humano, no pueden usarse entre creyentes y en defensa de la verdad de Dios. La investigación histórica, también en el campo de la religión, es lícita, independiente del control de la teología, porque en la manera en que éste se ejerce hasta ahora no es otra cosa que el control de la ignorancia sobre la ciencia. Una advertencia: no es legítimo imponer como realidades históricas del pasado las representaciones teóricas de ese pasado, tal como las había elaborado «une scholastique insouciante de l'histoire».

Iba a seguir su camino, aun sabiendo el precio. Lo pagaría ${ }^{74}$.

Una vez en la calle L'Évangile et l'Église, se desencadenó lo que Loisy llama «un tumulte théologique» No era razonable ese «charivari», dado que la tesis de Loisy era que, si había una esencia del cristianismo, tal como recogía el título de Harnack, la había perpetuado el cristianismo católico y que las transformaciones del Evangelio en el catolicismo no habían sido ni una decadencia ni una alteración progresivas.

Loisy hacía una crítica de las fuentes evangélicas más radical que la de Harnack. Era, a la vez, el abandono de las tesis escolásticas sobre la institución formal de la Iglesia y de los sacramentos por Cristo, la inmutabilidad de los dogmas y la naturaleza de la autoridad en la Iglesia. Iba más allá de la crítica. Proponía su libro una reforma de le exégesis, de la teología oficial y del gobierno en la Iglesia ${ }^{75}$.

A finales de noviembre, el cardenal Mathieu le preguntó si conocía la reacción de la Santa Sede ante sus libros. El 31 de diciembre inicia en L'Univers

74 «Que de choses à dire, mais que de colères encore à soulever! Je ne crois pas néanmoins qu'il y ait lieu d'hésiter. Après tout, l'interêt de l'Église est engagé dans cette affaire, et il importe que l'avenir du catholicisme ne soit pas abandonné à une troupe de fous et des menteurs entraînant après eux une papauté trop politique et un épiscopat trop ignorant», nota de su diario 17 de noviembre 1902, ibidem, 158-159.

75 Tras la condena de Action Franaise, Loisy destaca la perturbación que supone sustituir el amor como primera virtud del cristianismo, por la obediencia al papa como primera virtud del catolicismo, ibidem 169. 
una campaña contra L'Évangile et l'Église Gayraud, un sacerdote diputado por Finisterre, un ex dominico que militaba en la «démocratie chrétienne» ${ }^{76}$.

Cuando se agudizaron las presiones, se apartó de von Hügel ${ }^{77}$, pero respondió a la sugerencia de su otro gran amigo, Eudoxe Mignot, a quien Loisy y el barón llamaba «notre père». No haría una edición nueva con notas, sino que redactaría otro texto. Será Autour d'un petit livre.

Así las cosas, Loisy juzgaba que el inicio de la querella modernista no tenía su origen en sus dos libros. Fueron sus opositores los que llevaron a la mirada «sur la debâcle de la vieile théologie». Sabía que nada de eso «salvaría» el sistema romano. Sabía también que todas las maniobras contra él no le harían daño en la opinión de la gente honesta ${ }^{78}$.

\section{CONDENA DE L'ÉvANGILE ET L'EgLISE Y LA RESPUESTA DE LoISY}

Un decreto del cardenal Richard del 17 de enero de 1903 condenaba L'Évangile et l'Église. Ese mismo día Félix Klein, amigo de Loisy, le anticipó la noticia de que el cardenal Richard iba a condenar el libro ${ }^{79}$. La condena se basaba en dos motivos: había sido publicado sin el imprimatur y su contenido podía turbar gravemente la fe de los fieles en los dogmas fundamentales y en la enseñanza católica, señalando algunos puntos: la autoridad divina de la Escritura, la divinidad de Jesucristo, su ciencia infalible, el valor redentor de su muerte, la resurrección, la eucaristía y la institución divina del papado y del episcopado. Loisy detuvo la impresión de la segunda edición. Creía que eso bastaba para cumplir con la disciplina eclesiástica.

Se encargó en enero de 1903 el nuncio de reclutar adhesiones de los obispos a la condena del cardenal de París. No tuvo mucho éxito. Le respondieron siete, algunos de ellos de manera indirecta, entre ellos el cardenal Adolphe Perraud, obispo de Autun desde 1884. Perraud fue superior general del Oratorio en Fran-

\footnotetext{
76 Gayraud era, según Mignot, «un scolastique qui s’imagine de réfuter un historien rationaliste, avec son système théologique tout à fait». No compartía esa opinión Loisy, muy sensible a todos esos «apologistas», que tenían para su jefe de fila en Pierre Batiffol, ibidem, 184-189.

77 «Decía que el barón tendía a interpretar los textos de la Iglesia como se hacía con las cláusulas de los tratados internacionales cuando se busca el modo de no sentirse obligado por ellas. Estaba equivocado, porque en la Iglesia sucede lo contrario. No ha lugar para decir a la otra parte lo que piensa, se le atribuye y basta. El cardenal Richard se lo confirmará, ibidem, 183.

${ }^{78}$ En aquel momento, pese a sus relaciones difíciles con Duchesne, agradecía que quien mejor conocía los orígenes del cristianismo hubiera aprobado su libro. Ese gesto valía más que «les clameurs de cent mille Gayrauds», ibidem, 190-192.

79 Texto, Mémoires..., tome II, 194.
}

Hispania Sacra, LIX

120, julio-diciembre 2007, 633-706, ISSN: 0018-215-X 
cia. Pasaba por ser una persona culta ${ }^{80}$. Fue en este caso «le plus zélé» de los obispos preocupados por las nuevas ideas y por la acogida que tuvo el libro de Loisy el año anterior ${ }^{81}$.

Benedetto Lorenzelli, nuncio en París, fue autor de un manual de teología, que tuvo gran autoridad. Era, según expresión de Mignot, una persona que todo lo resolvía acudiendo a Santo Tomás. Eso no negaba su gran inteligencia, la tenía, pero «tout à fait fermé aux questions critiques» ${ }^{82}$.

Unos años antes, subrayaba Mignot que los teólogos no se ocupaban de los hechos. Eran unos idealistas. Les molestaba la realidad. La desdeñaban. Se transformaban en «vrais jacobins de la pensée au même temps que des rêveurs métaphysiques». Gente que, como sus predecesores revolucionarios llevaban sus premisas hasta la guillotina. Los jacobinos del pensamiento cortan igualmente con la frialdad de un cuchillo de acero. Los hechos no existen y los razonamientos no les afectan. Viven en la abstracción y pasean las afirmaciones brotadas de su serena infalibilidad ${ }^{83}$.

En el verano de 1903 pronunció Félix Klein unas conferencias sobre el fenómeno religioso. Hubo de sustituir ese término por hecho. Benedetto Lorenzelli creía que la religión era «pura realidad», recordará Loisy. Detrás de ese cambio, había una intervención León XIII y del cardenal Francesco Satolli. Se ordenó la destitución inmediata del rector del seminario del Instituto Católico y la del profesor Klein. El cardenal François Richard y el P. Lebas, superior de la Compagnie de Saint-Sulpice, aconsejado éste por Pietro Gasparri, dejaron en un cajón «cet ordre insensé» 84 .

80 Subraya Aubert, junto a sus buenas cualidades, su preocupación por mantener su reputación como persona entregada al «apostolado de la ciencia». Desconfiaba de las ideas nuevas. Un perfil crítico de Perraud, Albert Houtin, Évêques et diocèses, Ière. série, Paris 1908, 5-42.

${ }^{81}$ Roger AuBERT, «Aux origines de la réactions antimoderniste. Deux Documents inédits»..., 558569. Lorenzo BEDESCHI, «Saggio introduttivo a A. Loisy..., 7-65, recogido en Fonti e Documenti 15 (1986), por el que citamos, 92 y 104-109.

${ }^{82}$ Cuando fue elegido Benedicto XV, Lorenzelli, junto con Billot y De Lai, habría hecho campaña contra el cardenal Pietro Maffi, arzobispo de Pisa. Vid., la noticia en carta Macchi-Umberto Benigni, sin fecha, pero respondida por éste el 20 septiembre 1914, ASV Fondo Benigni 548446528 . Fue el protector del P. Mattiusi, sucesor de Billot en la Gregoriana. Pese a eso, el jesuita fue destituido a la muerte del P. Xavier Wernz. «La cas Mattiussi», octubre 1915, ibidem 26 3457c y d 257-259. En 1905, el P. Giovanni Genocchi señalaba a Lorenzelli entre los cardenales del entorno del nuevo Papa. Emilio D’Angelo, «Il Giovanni Genocchi», Palestra del Clero 2 (1966) 85-94. Lorenzo Bedeschi, Riforma religiosa e curia romana all'inizio del secolo. Milano 1968 y La curia romana durante la crisi modernista. Episodi e metodi di governo. Parma. 1968.

${ }^{83}$ Mignot-Loisy, 15 octubre 1899, Louis-Pierre SARDELLA, Mgr. Eudoxe Irénée Mignot..., 610-611 y 613-614.

${ }^{84}$ Una alusión en esta carta a los paseos que Loisy y Klein hacían por «Bois de Meudon» comprometió al profesor del Institut Catholique. Mémoires..., tome II, 252-254. 
Como era habitual en él, von Hügel creía el 21 de enero que se paraba así una intervención de Roma. Daba por supuesto que había sido una iniciativa del cardenal. De momento quedaba aplazada la traducción al inglés.

Otras reacciones inmediatas recibió Loisy. La más valorada por él, la de un seminarista de Saint-Sulpice, al que no contestó para no comprometerlo. Quería mantenerse en paz ${ }^{85}$. Mignot le sugirió que, si no pensaba escribir al cardenal Richard, debería publicar inmediatamente su Autour d'un petit livre. Lo hizo el 5 de febrero. Le comunicaba su decisión de no reeditarlo y de retirar los ejemplares que quedaban de la primera edición. Juzgaba que con eso obedecía, pero como hizo luego, también ahora se reservaba su opinión personal. Le agradecía su invitación a una entrevista personal, porque ese acto era muy duro para él y temía que lo fuera también para Richard. Esos mismos días comentaba a von Hügel que esos días era la persona más difamada de Francia ${ }^{86}$. Podía ser utilizado como un símbolo, como un nuevo «affaire Dreyfus» 87 .

Si se descalificaba a Loisy públicamente, se produciría un inmenso escándalo entre los disidentes, a los que su posición y sus escritos invitaban a regresar, por el único camino que era ahora posible. Supondría dentro de la Iglesia el hundimiento de la vanguardia científica, tan cruelmente puesta bajo sospecha a priori. El resultado sería que el clero, con una violencia aún más apasionada, porque aparecería a sus ojos como más santa, se lanzara, a una piedad medieval, obstinadamente cerrada a los ecos de fuera, a cualquier movimiento del espíritu de este tiempo, guardando, con un celo feroz, el depósito secular de una fe que se ha confiado para ser transmitida. Sería regresar a la política practicada desde hacía doscientos años ${ }^{88}$.

Examinando lo sucedido, Loisy deseó dejar claro que la polémica modernista, el escándalo que se había reprochado a sus escritos, procedían del fracaso de quienes trataron de refutarlos, recurriendo en muchos casos a injurias e insinuaciones calumniosas. Fueron ellos los que atrajeron la atención sobre el derrumbamiento de la vieja teología. Habían vociferado que aquellos libros negaban la

\footnotetext{
${ }^{85}$ En sus notas del 25 de enero describe la reacción de quienes asistían a sus cursos: más gente y un fuerte aplauso al iniciar su clase. «J'ai ne rien dire, et j'ai commencé mon tours comme d'ordinaire», ibidem, 203-204.

${ }^{86}$ Suprimió este texto: «Il est fâcheux, Monseigneur, que les décisions ecclésiastiques intervenues dans cette affaire semblent faire écho à des articles polémiques qui sont des chefs-d'œuvre d'ignorance, quand ils ne sont pas des chefs-d'œuvre de déloyauté». Citará expresamente a Pierre Batiffol, al que acusa de ser un ejemplo de odio y de perfidia, ibidem, 208 y 214-215.

${ }^{87}$ Pierre Dabry escribió a Paul Sabatier el 24 de febrero de 1903, una vez que estalló la polémica sobre L'Évangile et l'Église: «Si je me sentais les reins solides, je ferais de l'affaire Loisy une sorte de l'affaire Dreyfus dans le catholicisme». Emile Poulat, Histoire, dogme et critique..., 157 nota 60.

88 Johannes Wherlé-Blondel, 4 y 5 enero 1903, en René MARLÉ, introducción a Au coeur de la crise moderniste. Le dossier inédit d'une controverse. Lettres de Maurice Bolndel, Henri Bremond, Fr. von Hügel, Alfred Loisy..., présentées par..., Aubier, Éditions Montaigne 1960, 54.
}

Hispania Sacra, LIX

120, julio-diciembre 2007, 633-706, ISSN: 0018-215-X 
divinidad de Jesucristo y la autoridad de la Iglesia. Eso atrajo la atención de gentes que jamás habrían leído dos líneas. Con sus antologías de citas para refutarlos, habían difundido su contenido entre el clero.

Esa falta de honradez en la controversia llevó a la opinión, a través de los diarios, los problemas que sólo preocupaba entonces a unos pocos creyentes instruidos. Si no se hubiera actuado así, la crisis modernista hubiera sido menos violenta y peligrosa para la Iglesia y quizás ni se hubiera producido. Fue este el único punto que tachó en su carta dirigida al cardenal Richard el 5 de febrero, el mismo día en que escribió también a von Hügel, resumiendo su situación: «Le pauvre petit volume (L'Évangile e l'Église) a fait de moi l'homme plus diffamé de France».

Había una excepción entre los adversarios: Léonce Grandmaison. Publicó el 20 de enero en Études, un artículo «sensé, modéré, nullement flatteur», con un tono muy digno. Era una persona honesta, con la cual Loisy creía poder discutir. No escribió como cobertura a la condena hecha por el cardenal. Había sólo un cambio de tono: el del párrafo final, escrito por el P. Brucker, el director de la revista de los jesuitas ${ }^{89}$.

La condena de su libro le había escarmentado. La tesis de L'Évangile et l'Église es que la Iglesia es el evangelio continuado. El desarrollo cristiano no es exterior ni ajeno al Evangelio. Y eso puede probarse históricamente, dejando a un lado el carácter divino del evangelio y de la Iglesia.

Harnack admitía la divinidad del Evangelio. Loisy probaba que la Iglesia es el evangelio. Eso conduce, en la lógica de Harnack, a probar la divinidad de la Iglesia. Loisy había escrito esta respuesta, porque nadie lo había hecho antes. Con humor, advertía que en otra ocasión dejaría la tarea a los ortodoxos. Creía que el libro no negaba dogma alguno. En él se planteaba la necesidad de renovar toda la enseñanza teológica desde el punto de vista de la historia, «pour la rendre positivement plus vrai et, au point de vue philosophique, pour le rendre théoriquement plus intelligible». Esta tarea superaba su capacidad. Nadie debería reprocharle no haberla hecho ${ }^{90}$.

A mitad de febrero de 1903, tras escribir el día 5 al cardenal manifestando su sumisión en el ámbito disciplinar. El 22 de febrero tenía redactado su Autour d'un petit livre, pero aún no en forma de cartas.

La situación era muy complicada. Estaban en juego muchas cosas. No cabía una paz que no respetara a la autoridad, alos defensores de la tradición y a los críticos. Von Hügel parecía indicar a Loisy que había que detenerse. Más allá,

\footnotetext{
${ }^{89}$ Mémoires..., tome II, 189, 208, 215 y 198.

${ }^{90}$ Loisy-Blondel, 11 febrero 1903, en Marlé, René, introducción a Au coeur de la crise moderniste. Le dossier inédit d'une controverse..., 84-85.
} 
se traspasaba la moderación y se faltaba a la verdad. Incluso le aconsejó que hiciera una edición de sus escritos con el imprimatur. No lo sentía así Loisy. La autoridad eclesiástica debía someter a su autorización los libros litúrgicos, los libros de piedad, los manuales para la enseñanza en los seminarios. Para los otros bastaba que se reservara el derecho recensurarlos llegado el caso.

Sabía que eso no era posible, porque Roma «n'admet aucune limitation dans son absolutisme; c'est le principe même de son contrôle qui est absurde». No podía modificarlo, porque esa decisión le obligaba a alterar todo el sistema. Esos días rechazó un viaje a Roma, bromeando incluso ${ }^{91}$ y dejando para más adelante su apología.

Esos días, como apuntó el 13 de noviembre estaba vitalmente en otro ámbito. En la segunda mitad de febrero recibió una carta extensa de Blondel. Su demanda de autonomía para la crítica histórica, además de un asunto científico, era un camino elegido para entender el cristianismo:

«Je vous avoue que un miracle me paraît plus grande que ne le serait la conscience d'un Deus-homo, c'est l'invention, très rapide, en somme, des idées et des textes que vous estimez interprétatifs et fictifs, s'il n'y a pas dessous une réalité agissante, qui en explique la nouveauté prodigieuse, la portée déconcertante, la convergence malgré la diversités de ses origines, la plasticité indéfinie dans la précision la plus belle»92.

Para complicar su situción, lo que Loisy llamaba «teólogos laicos» de La Sorbonne no estaban dispuestos a renovar su contrato para el curso 1903-1904, por haberse sometido a la condena de L'Évangile e l'Église. Entonces, una nueva carta de Mignot lo decidió a escribir su Autour d'un petit livre, ahora en forma epistolar. Dudó a mitad de abril sobre la conveniencia de publicarlo.

Dos hechos nuevos: se entera a mitad de junio de que en Roma no han condenado su L'Évangile e l'Église porque esperaban que dejara de publicar. Si no lo hacía, condenarían todos sus escritos. La edición alemana iba salir en octubre. Había tomado una decisión: defender su libertad científica. Esperar no le beneficiaba. ¿Por qué hacerlo?

Autour d'un petit livre era una apología de L'Évangile e l'Église. Por eso en el prólogo afirma: «La première condition du travail scientifique est la liberté. Le premier devoir du savant, catholique ou non, est la sincérité». Era todo un gesto. Esos mismos días, Klein, atacado por la Vérité Française, defendió su ortodoxia, diciendo que sólo respiraban sus escritos «la pure doctrine et l'amour de l'Église».

91 «Mes tours ne sont pas en sûreté qu'à Bellevue. Si ye venais a mourir à Rome, tout le monde coirait qu'on m'y a aidé et he ne pourrais pas protester contre cette calomnie».

92 Alfred Loisy-Maurice Blondel, 27 febrero 1903, Memoires..., tome II, 220-228.

Hispania Sacra, LIX

120, julio-diciembre 2007, 633-706, ISSN: 0018-215-X 
Era consciente de que la parte más arriesgada de su Autour d'un petit livre era la quinta carta sobre la Iglesia. Iba dirigida a Felix Klein, que personificaba al apologista católico. Era un ortodoxo, con un aire inofensivamente liberal, que le daba un buen estilo. Trataba del fundamento de la autoridad en la Iglesia. Loisy atribuía la fundación de la Iglesia al Cristo resucitado. Ha nacido de la fe en Él. La autoridad en la Iglesia, como en cualquier otra institución, es una función de educación cultural, no un poder absoluto dominador. Era un servicio y sólo eso. Lo que era aplicable a una sociedad rectamente ordenada, valía para la Iglesia. Hasta ahora parecía ocuparse casi exclusivamente de su autoridad. Debería hacerlo en adelante, de los derechos del cristiano. Después de diecinueve siglos de cristianismo se había llegado a la primacía de la sede de Roma y a la infalibilidad del Papa. Esta evolución se justificaba si permitía al sucesor de Pedro hacer más fáciles y con mayor prontitud las reformas y todos los progresos que exigían los tiempos. Ese cúmulo de poder sólo puede subsistir siendo el órgano para atender las aspiraciones de los creyentes. Eso significaba descentralizarse, hacerse todo para todos, en lugar de querer absorber todo.

La cuestión capital era que el pensamiento humano era esencialmente relativo y el lenguaje humano era por naturaleza simbólico. Cuando el libro estaba concluido daba sus primero pasos el nuevo Papa ${ }^{93}$.

Consideraba von Hügel L'Évangile e l'Église una obra que había puesto en circulación para los siguientes cincuenta años las ideas necesarias para el público y para los críticos sinceros. Estaba pagando en sufrimientos su gran labor. Pedía la bendición de Dios sobre Loisy.

Era este un punto en el que disentían los dos amigos. Loisy era especialmente sensible a los que que calificaba como «l'aveuglement des théologiens». Eso les daba una seguridad incluso ante las censuras de la Iglesia que no tenían. Pero quienes las sufrían y hasta para la Iglesia misma, esa persecución tan encarnizada por medio de «les trravailleurs de l'intelligence» debían considerarla una fuente de bienes más valiosos que la posesión de la verdad. No era fácil ni definir ni constatar esos bienes. Lo más evidente era que la inteligencia de von Hügel no la desconcertaban ni el fanatismo ni las más absurdas exigencias de la autoridad de Roma, que no aceptaba límites a su poder absoluto, porque cualquier modificación pondría en crisis todo el sistema.

Páginas adelante, Loisy señala que en diciembre de 1902, Dillon publicó «Catholicism versus ultramontanism», Contemporary Review, una severa crítica del sistema ultramontano. Señalaba los casos de opresión cometidos por él y la impotencia de personas sensatas como Mignot. El catolicismo se iba centralizando más y más en Roma. La religión pasaba a segundo plano y se ponía al

93 Mémoires..., tome II, 220-258. 
servicio de la política, tratando de unir la democracia al carro del absolutismo pontificio.

Esos días Loisy estaba especialmente sensible ante la operación para condenarlo. Citaba a M.-J. Lagrange y a quienes se habían inventado que León XIII lo había recibido en audiencia ${ }^{94}$.

Respondiendo a una carta de Maurice Blondel, del 15 de febrero, Loisy explicaba sumariamente las relaciones teología-crítica. Se supone que el cristianismo es transcendentalmente verdadero en su sustancia teológica, entonces lo que hay que hacer es explicar los textos. De ese modo se vuelve al revés lo que debe hacer la crítica ${ }^{95}$.

Condenado Loisy por el arzobispo de París e incluido su libro en el Indice, Mignot hizo balance. La verdad está más del lado de los críticos sabios y moderados. El mundo intelectual iba en esa dirección. Los católicos continuaban siendo «géocentristes», no en astronomía, pero sí en otras muchas cosas. Por eso los intelectuales y las personas cultas daban la espalda a la Iglesia.

«M. Loisy inquiète bien des esprits, j'en conviens, mais si au lieu d'agir avec lui comme on l'a fait, on lui avait témoigné plus de confiance, on l'aurait rendu rassurant; on l'aurait amené à défendre les Saints Livres contre les rationalistes, on en aurait fait un remarquable apologiste. Hélas, au lieu du compelle intrare, il semble que le devise soit compelle exire» ${ }^{96}$.

EL «LOISYSME»

El nuncio Lorenzelli apeló a Roma en junio. Dado el ascendiente de Alfred Loisy entre el clero joven, pensó solicitar la condena formal del libro. Había escándalo o sorpresa entre los católicos por el silencio de Roma. El autor de $L^{\prime} E$ vangile et l'Église continuaba exponiendo sus teorías en las clases que impartía en la Sorbona. Los más sensatos e instruidos eclesiásticos se asociaban al nuncio en la opinión de que la Santa Sede debía pronunciarse. No era suficiente la condena por parte del arzobispo de París. Era seguro que Loisy y sus seguidores reaccionarían negando que en su libro hubiera errores. Sus atrevidas teorías no eran aptas para ser oídas por los fieles. Esa precisión aconsejaba publicar una Carta Apostólica citando las afirmaciones condenadas.

\footnotetext{
${ }^{94}$ Alfred Loisy-Maurice Blondel, 27 febrero 1903, Mémoires..., tome II 222-224 y 235-236.

${ }_{95}$ Alfred Loisy-Maurice Blondel, 27 febrero 1903, Mémoires..., tome II 228.

96 Mignot-Lucien Lacroix, 17 marzo 1903, Louis-Pierre SARdella, Mgr. Eudoxe Irénée Mignot (1842-1918)..., 391.

Hispania Sacra, LIX

120, julio-diciembre 2007, 633-706, ISSN: 0018-215-X
} 
Atacaba la filiación divina de Jesús y su divinidad, insistiendo en que Jesús no tenía más que una personalidad divina, la fundación de la Iglesia por Cristo, la diferencia establecida también por Cristo entre Iglesia triunfante e Iglesia militante, el carácter expiatorio de su muerte y la naturaleza divina de los dogmas católicos, la institución del primado de jurisdicción de Pedro y la verdadera razón por la cual el obispo de Roma es su verdadero sucesor, la institución divina de los sacramentos y su eficacia ex opere operato... El nuncio insistía en el adjetivo «inmediato» para referirse a la fundación de las instituciones de la Iglesia por Cristo.

La exégesis de Loisy contradecía la letra y el espíritu del Evangelio, la tradición de los Santos Padres y las definiciones de los Concilios. Eran radicalmente subversivas. «Trattandosi di tutto un sistema e di una scuola, che snatura e sovverte il cattolicismo intero, è desiderabile che la sua condanna rivesta il carattere più solenne e magistrale, onde sia più efficace e durevole».

No era prudente dejar pasar el tiempo. Ni podía esperarse una retractación voluntaria de quien proseguía difundiendo sus ideas, ampliando además las razones para defenderlas. No era previsible que la condena trajese mayores males. El único riesgo era la posible apostasía pública de Loisy y que le siguiera algún sacerdote. En cambio, una posición clara por parte del Papa sacaría de la perplejidad a muchos, profesores y alumnos, que estaban indecisos y a quienes la inhibición podría inclinar al lado equivocado ${ }^{97}$.

Tenía Loisy decidido ya a finales de junio publicar, Autour d'un petit livre, las cartas en las que defendía su L'Évangile e l'Église, del que estaba preparando una segunda edición ampliada. La idea central: hay una diferencia de perspectiva entre teología e historia. Era esta su prioridad. Su decisión, «maintenir coûte que coûte ma liberté scientifique, e il va sans dire que je ne croyais pouvoir la maintenir autrement qu'en m'en servant». En el prólogo escribió: «La première condition du travail scientifique est la liberté. Le premier devoir du savant catholique ou non, est la sincérité» 98 .

Ocho días después de la muerte de León XIII, Loisy recordaba que Minocchi dio a leer L'Évangile e l'Église al cardenal Sarto, porque era papable. «Mais le pape pourrait faire condemner ce que le cardinal a trouvé innoffensif». La persona tenía su papel, pero «il faut compter avec la machine» de la curia, aun muy fuerte, pese a que existía ya una poderosa opinión contra ella. «Marcher sans crainte, parler sans colère, agir avec calme», así fijaba su rumbo de «hombre del justo medio» ${ }^{99}$.

971748 Benedetto Lorenzelli-Rampolla, París 22 de junio de 1903, ASV SS 82 (1908) 8, 114-117.

98 Alfred LoIsY, Mémoires..., tome II, 246-248.

${ }^{99}$ Alfred Loisy-Maurice Blondel, 27 febrero 1903, Mémoires..., tome II 259. 
Desde el 5 de octubre, el obispo de Autun, cardenal Perraud, había dicho que Autour d'un petit livre era «une aggravation audacieuse des thèses précédemment soutenues». Loisy le envió un ejemplar. Lo leyó y se puso a trabajar para exterminar el «loisysme», que era más peligroso que el «renanisme». El cardenal Richard viajaba a Roma con un «mémoire», trabajado por el supulciano Letourneau y el jesuita Bouvier. Contenía 33 proposiciones sacadas de los dos libros. Otros dos cardenales, Benoit-Marie Langenieux, de Reims, y PierreHector Couillié, de Lyon, pidieron que se condenaran los dos libros y las proposiciones. Fue recibido el arzobispo de París por Pío X el 1 de noviembre. Estuvo en Roma hasta el día 18.

Duchesne escribió a Loisy el 26 de octubre. Su tono queda reflejado en dos párrafos: no compartía su optimismo de pensar compatibles la crítica y el catolicismo, al menos no como la entendía Duchesne, o mejor, como lo exigía «l'etat actuel de l'inrformation». Harnack juzgaba posible que las ideas de Loisy entraran entre la gente religiosa de su confesión. No lo creía Duchesne. En esa dramática contradicción entre la necesidad y la imposibilidad de evolucionar, otorgaba a Loisy el mérito de haber trabajado en ello «et aux prix de quels dangers».

El 11 de noviembre Mignot escribió a Merry del Val. Era un texto muy pensado y el 21 lo hizo a Loisy. Le decía que, al responder a un mensaje del clero de Albi, Pío X invitaba al arzobispo a mantener a sus asacerdotes «dans les principes de la foi traditionnelle, au milieu des temps malhereux que nous traversons». Su clero era poco instruido y podría creer fácilmente que el arzobispo protegía a un hereje. El 23 von Hügel se preguntaba si no debería Loisy marchar a Roma y, por medio de Genocchi, del franciscano inglés, el P. David, o del jesuita Gismondi, pedir una audiencia al Papa. Loisy creía mejor esperar la llamada de Mignot, que viajaba esos días a Roma.

En la primera quincena de diciembre, Richard escribió al Papa. Siguiendo su indicación, había recogido más información. Después de eso, había llegado a la conclusión de que las obras de Loisy eran un peligro real y muy grave para la fe. Los confesores le decían que estas doctrinas perturbaban a los católicos. Se felicitaba, en cambio, la prensa hostil a la religión. El cardenal deseaba una condena de los libros de Loisy, de su doctrina, de su enseñanza, de toda su obra. Junto a él estaban los otros tres cardenales, el de Lyon, el de Reims, el obispo de Autun. Añadía: los obispos que quieren evitar la condena de Loisy, quizás «ne soient pas placés dans les circonstances des lieux et des personnes» que les permitieran apreciar el daño que causaban esas obras a la fe.

Conoció Loisy, a través de Henri Bremond que el Papa había leído los dos libros y los había anotado: se negaba a condenar a una persona que juzgaba 
leal y de buena fe. Hubo otra noticia: dos publicaciones de Charles Denis, director de los Annales de Philosophie Chrétienne habían sido incluidos en el Índice. Estos escritos recogían sus predicaciones cuaresmales en Albi y en Bourges.

La secuencia de los hechos fue: 16 de diciembre, condena de cinco libros de Loisy ${ }^{100}$. Jueves 17, el Papa lo aprueba. El sábado 19 se envía el texto al cardenal Richard. La información de Bremond y la que Genocchi le transmitió el 14 de diciembre sobre la buena disposición del Papa, tal como lo había dicho Mignot, quedaron desmentidas. Cuando el arzobispo de Albi se despide del Papa el 22 de diciembre, resume así su estancia en Roma: «J'étais arrivé plein d'espoir, et je pars plein de tristesse» ${ }^{101}$. La explicación del cambio las atribuía el arzobispo a las presiones sobre Pío X. En la audiencia le informó el Papa de la decisión, que aún no había sido publicada.

Loisy pensó que hubo interés en no implicar al Papa. En el decreto se hacía un juicio doctrinal. Eso significaba que no bastaba con una sumisión externa, pues no era un asunto disciplinar, sino doctrinal. Los cinco libros estaban llenos de errores. Fueron incluidos en el Índice en la sesión del 4 de diciembre. La intervención del Santo Oficio, fechada el 23 de diciembre, reforzaba la autoridad de la medida y el rigor con el que debía ejecutarse ${ }^{102}$.

El 29 de diciembre, sin saber cómo actuaría el cardenal Richard, Loisy escribe a von Hügel: «je suis décidé à recevoir avec respect la condamnation, sous réserve expresse du droit de ma conscience et mes opinions d'historien».

Conocido el hecho extraoficialmente, comenzaron las condenas episcopales. La de Châlons, diócesis de origen de Loisy, estaba ya anunciada. Esperaba Loisy contar con más amigos y apoyos que cuando fue expulsado del Institut Catholique en 1893. Lucien Lacroix recordaba a sus fieles la condena de Fénelon: no lo abandonó ninguno de sus amigos.

Decía a von Hügel en su carta del 29 de diciembre: salvaría de este naufragio todo lo que pudiera. Lo primero, su honor como cristiano, que quedaría gravemente lesionado con una sumisión «ciega». Von Hügel reconocía la gravedad de lo sucedido, especialmente la carta de Merry del Val a Richard, pero pedía a Loisy: «restons calmes et prudents». Le enviaba unos argumen-

${ }^{100}$ La Religion d'Israel, Etudes evangéliques, L'Évangile et l'Église, Autour d'un petit livre y Le Quatrième Évangile. El documento de condena, ASV SS 82 (1908) 8, 132.

${ }^{101}$ Le informó con más detalle de las dos audiencias con Pío X el 28 de diciembre, en una carta escrita en Hyères, en la Costa Azul. El arzobispo parecía decidido a conciliar lo que la Santa Sede declaraba inconciliable. Cuando recibió los documentos oficiales, reconoció que la situación era muy grave. La única salida que encontraba era que hubieran querido evitar ulteriores condenas.

${ }^{102}$ El texto del decreto del Santo Oficio, la comunicación al cardenal Richard y su carta autógrafa a Loisy, a quien enviaba estos documentos, Mémoires..., tome II, 299-301. 
tos que Loisy calificaba con algo de ironía «une métaphysique de la situation». Como decía el autor de «Lettere Romaine» la condena nada solucionaba ${ }^{103}$.

Esos días le preocupaba que su amigo, Albert Houtin, abandonara la Iglesia. Dos de sus obras habían sido incluidas en el Índice. Una carta del arzobispo Mignot, a mitad de enero, dejaba en evidencia la soledad de Loisy ante los altos cargos del Santo Oficio y de la Congregación del Índice. Su secretario, Thomas Esser, bien dispuesto hacía él, decía que estaba fuera del catolicismo, su exégesis era protestante, subjetivista...

Las cartas entre Saunders y Loisy, 6 y 8 de enero fueron publicadas en The Times el 30 de abril de 1904. Loisy quiso que von Hügel conociera la parte de su texto censurada. En ella subrayaba lo insólito del procedimiento. El decreto no daba motivos, se limitaba a encargar a Merry del Val que los explicara al cardenal Richard. Pero esa carta no era un documento oficial del Santo Oficio. Creía que se había actuado así para cubrir con la autoridad del Papa. Se hablaba de errores, pero no se enunciaban ${ }^{104}$. Por eso la carta del arzobispo de París se limitaba a aconsejar a los sacerdotes a que no se fíaran de la doctrina de Loisy y, para evitar mayores peligros, les prohibía que leyeran los libros condenados.

Loisy no necesitaba expresar su posición, expuesta ya en L'Évangile e l'Église y Autour d'un petit livre ${ }^{105}$. El 23 de enero visitó al cardenal Richard. Quiso este exponerle en persona el mensaje del Santo Oficio. Insistió en que su refutación de Harnack era débil. Le anunció, «en toute mansuetuede» que el paso siguiente sería una condena nominal y pública. Loisy se negó a la retractación que se le exigía. Richard le respondió entonces que había

103 Alfred LoISY, ibidem 268-296. La primera versión de Lettere Romane apareció en los Annales de Philosophie Chrétienne (janvier-mars 1904). Un resumen de 46 páginas, Lettres Romaines. Critique historique et foi chrétienne, Paris, Roger et Chernovit 1904. Se sabe que el texto es obra de Giovanni Semeria y que fue revisado por Frederich von Hügel. La traducción italiana fue obra de Brizio Casciola. Tortonese y el mismo don Brizio Casciola creían que era una obra de Frederich von Hügel. Estas seis cartas eran una síntesis de lo expuesto por Loisy en sus dos pequeños libros rojos. Iban dirigidas a un amigo y tenían un tono confidencial. Loisy representaba una generación, no era un solitario. Lorenzo BEDESCHI, «Saggio introduttivo a A. Loisy...», 7-65, recogido en Fonti e Documenti 15 (1986), por el que citamos, 153-155.

104 Loisy recordará que no incluyeron las proposiciones preparadas para el cardenal Richard. Lo hará en junio de 1907 el decreto Lamentabile sane. Quizás fuera uno de los efectos provocados por la denuncia de los puntos débiles de este decreto de 1903.

105 Recuerda Loisy a Saunders que habló en ellos del régimen intelectual del catolicismo, exponiendo su postura ante la censura. Expresaba su respeto a un acto de una autoridad cuya función era necesaria para conservar la verdad cristiana en el mundo, «mais ce respect ne fair pas tort à celui que je dois à la vérité chrétienne». Catholique j'étais, catholique je reste; critique j'étais, critique je reste», ibidem, 310-311.

Hispania Sacra, LIX

120, julio-diciembre 2007, 633-706, ISSN: 0018-215-X 
más: retractación, renuncia a los cursos en la École des Hautes Études ${ }^{106}$, dejar de publicar, retirarse a una casa religiosa para, dice Loisy, «me refaire una mentalité catholique» ${ }^{107}$.

En noviembre de 1903, Geremia Bonomelli, antes de que fuera condenada, comentó la obra de Loisy en forma de carta abierta a un párroco ${ }^{108}$. Al obispo de Cremona le bastaban los criterios generales teológicos y científicos para examinar L'Évangile et l'Église y Autour d'un petit livre. Reconocía al autor todas las buenas cualidades, como sacerdote y especialista, para ganarse la admiración, pero todas las expectativas quedaron defraudadas.

¿Qué estaba pasando entre los estudiosos? Unos consideraban ciertas doctrinas como axiomas, como dogmas. Todo estaba fijado y no cabía progreso. Otros, separándose de esta postura, caminaban hacía una ruptura con la tradición. Estos deberían recordar que los frutos maduran con el tiempo, sin arrebatos, lentamente.

Los escritos de Loisy tenían muchos pasajes oscuros. Desmentian la claridad atribuida a los franceses. Eso apuntaba a influencias alemanas o quizás a la necesidad de bajar el tono de expresiones fuertes que podrían chocar. Daba por probadas ciertas teorías o doctrinas.

Bonomelli destapa su propia actitud intelectual: hay que ponerse en el terreno del adversario para traerlo paso a paso al propio. No sucedía eso con Loisy en su refutación de Harnack. El ejemplo le lleva a salirse del plano crítico al teológico. ¿Es Cristo verdaderamente Dios o no? La lectura no despeja esa

106 El cardenal Richar denunciaba que bastantes sacerdotes jóvenes asistían a los cursos de Loisy en la École des Hautes Études. Se dejaban seducir por unas doctrinas, «qui répondent à l'état général des esprits». La situación era muy grave. «Les journaux hostiles à la Religion se felicitent de voir les Catholiques... travailler eux-mêmes à la destruction de la foi». Era oportuno y necesario un acto de la Santa Sede. Aunque se dijo que habían acudido a Roma el arzobispo de Albi y el obispo de la Rochelle para evitar la condena, la mayor parte de los obispos estaban a favor de que se hiciera. Richard-Merry del Val, 11 de diciembre, ASV SS 82 (1908) 8, 122-123.

${ }^{107}$ La conversación fue subiendo de tono. Su punto más dramático fue la duda del cardenal sobre la moralidad de Loisy, cuando le dijo que sabía que no se confesaba. El relato de esta entrevista, ibidem. 319-321. Lucien Lacroix citaba a Loisy en una carta escrita al clero de su diócesis, publicada el 15 de diciembre de 1903. Subrayaba que no había recbiido ninguna censura eclesiástica. Sus teorías podían desconcertar y eran atrevidas, pero todos los que lo conocían testificaban su piedad y su vida intachable, su erudición y su laboriosidad. «Lettre de Mgr. Lacroix, Évêque de Tarantaise, au clergé et aux fidèles de son diocèse. La lecture de l'Évangile», Bulletin Religieux du Diocèse de Tarantaise 6 (15 décembre 1903) 89, en Maurilio Guasco, «Lacroix, Semeria, Fogazzaro. Momento di un'amicizia», Fonti e Documenti 13 (1984), 208.

108 «Le opere dell' abate Loisy. Una lettera di Mons. Bonomelli», La Lega Lombarda, 12 novembre 1903, texto reproducido por Maurilio GuASCO, «Loisy e i Lombardi», Fonti e Documenti 2 (1973) 608613. Guasco recuerda que Pío X habló, si bien de forma genérica, de su estima por Loisy en la audiencia que concedió a Bonomelli, ibidem, 597. 
niebla. Deja así en el lector una laguna, «che non doveva lasciare». Más adelante, le censura que diga que la resurrección de Jesús no es un hecho históricamente demostrable. Era esa conclusión una consecuencia de separar de la teología la historia y la crítica ${ }^{109}$. La diferencia entre dogma y hecho histórico no es posible. Si lo fuera, quedarían como falsos testigos todos los apóstoles 110 .

Enumera Bonomelli un «catalogo» de afirmaciones ambiguas, inexactas y peligrosas. Se justificaba Loisy apelando a su condición de crítico. Esa razón no valía. Porque si se alargara la autonomía de la crítica, se iría al racionalismo. La crítica tiene límites. No es un árbitro absoluto. Esperaba que el tiempo dejara fuera dos tercios de las conclusiones que establecía ahora «la critica intemperante». Le molestaba que Loisy recordara que a Léon Taxil se le permitió publicar libremente, doloroso contraste con las limitaciones que a él se imponían. La observación era impertinente.

Preguntaba Bonomelli «quante anime condurremno a Cristo la erudizione, tutta la scienza ciencia, tutta questa «critica storica»? Quante anime ritrarremo dalle vie del dubbio e dell'incredulità? Quante confermeremo nella fede che vivifica?» El obispo dejaba al lector la respuesta.

Esta intervención creaba un conflicto en aquellos católicos italianos que admiraban a Bonomelli como obispo y a Loisy como sabio ${ }^{111}$. Antonio Fogazzaro, tan ligado a él, leído Autour d'un petit livre, afirmó que jamás había sido Loisy tan claro y tan valiente. Quedaría su nombre como el más bravo promotor de la renovación de las viejas fórmulas de la fe católica, cuyo ciego tradicionalismo quisiera hacernos aceptar la letra como una exacta representación de la verdad sobrenatural. No se le ocultaban los problemas que la obra tendría. No era un libro escrito para todos los públicos. Muchos creyentes sencillos se sentirían heridos. Eso haría su condena más fácil a sus adversarios. No le cabía a Fogazzaro la menor duda sobre esto. Pío X nada entendía de estos problemas. No estaba informado de ellos ni conocía la cultura moderna. Había vivido siempre en un ambiente intelectual rigurosamente tradicionalista ${ }^{112}$.

La crisis de los dos libros descubría una situación. Esos días de diciembre, recibió Loisy una carta de Lucien Lacroix, obispo de Tarantaise. L'Évangile

109 Insistió en esta distinción crítico, historiador y creyente como la base del error del Loisy en la entrevista que concedió a La Patria, 4-5 diciembre 1903, ibidem, 599.

${ }^{110}$ El 22 de diciembre, Antonio Fogazzaro escribía a Bonomelli: «...se noi avessimo le prove squisite della Risurrezione, quale sarebbe il nosotro merito di credenti e quale uomo ragionevole non crederebbe in Cristo?», ibidem, 598

111 Comentario, Giuseppe Gallavresi-Loisy, Milano 22 novieembre 1903, ibidem, 614. Gallavresi calificaba a La Lega Lombarda como conservador, católico e ilustrado.

112 Fogazzaro-Paul Sabatier, 13 noviembre 1903, en Emile PoUlAT, Histoire, dogme et critique..., 249.

Hispania Sacra, LIX

120, julio-diciembre 2007, 633-706, ISSN: 0018-215-X 
et l'Église era un análisis de los puntos débiles de la mentalidad católica. En la Iglesia no existía libertad de pensamiento. «Chacun paraît avoir peur de ses propres idées. Par crainte de sortir de l'orthodoxie, on renonce à user de sa propre raison et à faire oeuvre de critique. Pour chaque chose on se remit à l'autorité».

Parecía que nadie pensaba en la Iglesia, salvo algunos jefes de las congregaciones romanas, que daban la sensación de querer controlar la mentalidad de todos. Era una situación comparable con la de Rusia zarista. En la Iglesia se escuchaban ruidos inquietantes para el futuro del absolutismo intelectual, tan absurdo y odioso como el otro ${ }^{113}$.

Se comentaba entre los seguidores de Loisy: vamos a leer sus obras antes de que sean condenadas. Se sospechaba también de Klein. Aunque compartía las ideas de Loisy, el cardenal Richard no creía necesario apartarlo de su cátedra, pese a sus relaciones John Ireland y las simpatías hacia el americanismo antes de su condena. Tenía este profesor del Instituto Católico prestigio entre el clero joven y entre lo seglares.

El obispo de Nancy et Toul, Charles François Turinaz, denunciaba la complicidad de la Comisión Bíblica con estos «innovateurs». El responsable era León XIII, tan inclinado a hacer concesiones a los enemigos ${ }^{114}$. Llegaban a creerse en mayoría. Para muchos católicos la suspensión de sus actividades sería un alivio. Sus oponentes, pese a su buena formación científica, carecían de energía para frenarlos ${ }^{115}$.

El 18 de enero de 1904, se dijo al cardenal Richard que llamara a Loisy y que, en nombre de la Santa Sede, lo amonestara y pidiera su obediencia retractándose ${ }^{116}$. Hemos visto lo que dijo a sus amigos: respetando el juicio sobre sus obras, lo acataba como una medida disciplinar, que dejaba intactos los derechos de su conciencia. No se sometería ante ese juicio ni abandonaría o rectificaría las opiniones publicada en su condición de historiador y de exégeta crítico. Sus afirmaciones estaban en revisión continua, las había ido corri-

113 Émile Poulat, Modernistica. Horizons, physionomies, débats, Paris, Nouvelles Éditions Latines. 1982, 131.

${ }^{114}$ Esa conducta fue un error. Ahí estaba el ejemplo de la democracia cristiana. El Papa les permitió integrarse en la Opera dei Congressi. Se habían apoderado de su dirección, silenciando a quienes no pensaban como ellos. En Francia deseaban controlar la Jeunesse Catholique. Querían hacer de Marc Sangnier el Murri francés. Acababa de publicarse en La Semaine Religieuse, de Cambrai, que no había que preocuparse de la acción contra la Iglesia. Esos jacobinos sólo tocaban lo que había envejecido en ella.

115 Turinaz-Merry del Val, Nancy 10 de diciembre, ASV SS 82 (1908) 8, 122-123124-125.

${ }^{116} \mathrm{El}$ documento ASV SS 82 (1908) 8120. 
giendo en la medida en que avanzaba su investigación. Lo harían en lo sucesivo tanto él como otros ${ }^{117}$.

No era suficiente esa carta. Volvió a pronunciarse el Santo Oficio: que se sometiera sin restricciones ${ }^{118}$. Era un anticipo de lo que pasará en 1910 con el juramento antimodernista. El arzobispo de Albi no dudó en advertir que la condena había sido un acto excesivo ${ }^{119}$.

Fallaron algunas previsiones y había informaciones equivocadas ${ }^{120}$. Fernand Mourret transmitió a Blondel que condenarían a Loisy por un acto pontificio. El Papa, leído el libro, comentó: lo condenaré. Eso suponía dejar de lado al Santo Oficio, al Índice y a la Comisión Bíblica. Sería una decisión personal ${ }^{121}$.

La sumisión de Loisy el 4 de enero de 1904 no cerró el equívoco entre el método histórico y el dogmático, entre los teólogos de la escuela romana y él. Eran dos modos antitéticos de encarar el cristianismo. Los teólogos trasladaban de inmediato al terreno doctrinal los resultados de la investigación histórica. Identificaban las definiciones conciliares como asertos con base histórica. Esa «falsa historia», como la llama Poulat, se contraponía a la verdadera historia, la que hacía Loisy, cuyas conclusiones los teólogos calificaban como herejía. Ese equívoco fue creciendo antes del decreto Lamentabile sane y de la Pascendi Dominici gregis. En medio del conflicto con Tyrrell, el P. Luis Martín, prepósito general de la Compañía de Jesús, en una circular a los provinciales, pidió que

117 Copia de una carta de Loisy al cardenal Merry del Val, Bellevue 2 de febrero de 1904, ASV SS 82 (1908) 8, 119 y 121.

118 Se pidió al cardenal de París que insistiera ante Loisy. Documentos 4 y 5 de febrero, ASV SS 82 (1908) 8 141-143.

119 «Une condamnation rigoureuse... ne sera pas sans de graves inconvénients, et j'ai lieu de penser que ceux qui en France ont le plus vivement poussé à une condamnation ne sont pas sans crainte d'avoir été trop long... Pardonnez moi de Vous exprimer mes inquiétudes, peut être Votre Sainteté n'est elle pas suffisamment renseignée sur le mouvement d'opinion qui se prépare». Mignot-Pío X, 8 février 1904, ASV SS 82 (1908) 8144.

${ }^{120}$ Mourret dice que Mignot manifestó que Loisy le había proporcionado argumentos para evitar la condena. Mourret resume así la situación: cambió la situación a mitad de diciembre. Loisy quedó sin defensores ante la Santa Sede. El 21 de diciembre llegó al cardenal François Richard, arzobispo de París, la decreto de condena. El documento tenía dos partes: un juicio sobre las doctrinas de Loisy y una instrucción para el cardenal. El decreto había sido firmado por Pío X el 16 de diciembre. El elenco de los errores se extendía a 5 obras de Loisy. Este, en cuanto se supo la noticia, publicada en L'Univers el 27 de diciembre, expresó su intención de someterse y de retirar de la venta sus obras. Había algunos signos de alarma: las obras se vendían en el centro de París y algunos sacerdotes jóvenes abandonaban la Iglesia en medio de una crisis de fe.

${ }^{121}$ Cartas de Fernand Mourret-Blondel, diciembre 1903, en René, MARLÉ, Au coeur de la crise moderniste..., 166-169. Un dato significativo: cuando en 1913-1914 el Santo Oficio quiso condenar a Maurras y la Action Française, Pío X decidió también reservarse esa condena, que no se publicó después de ser aprobada por el Santo Oficio.

Hispania Sacra, LIX

120, julio-diciembre 2007, 633-706, ISSN: 0018-215-X 
no se apoyara el método crítico. Lo mismo hizo el P. Cormier, maestro general de los dominicos ${ }^{122}$.

Había sido Loisy el protagonista del intento más audaz, más nuevo y potente de apologética desde hacía mucho tiempo. Pese a sus limitaciones, el método era válido. Era triste que se imputase a Loisy haber desconocido unas verdades en cuya defensa había escrito. El Santo Oficio dejaba intacta toda la obra crítica de Loisy. Por eso después de esa aportación, la condena era «un gran crime».

Su revancha, debía ser seguir su labor, ahora parándose más en cuestiones concretas, más fáciles de tratar con mayor amplitud que cuando se entra en polémicas. Hacerlo con calma, con mesura, citando los principios teológicos recibidos en la Iglesia ${ }^{123}$.

\section{MODESTO, MODERADO, TRANQUILO ${ }^{124}$}

El 11 de enero de 1904 Loisy escribió a Merry del Val manifestando su respeto a las decisiones de las Congregaciones del Índice y del Santo Oficio. Su adhesión era puramente disciplinar. Se reservaba los derechos de su conciencia $^{125}$. Al acatar la medida, entendía que no estaba obligado a abandonar las opiniones de historiador y exegeta crítico. No les atribuía una certeza, porque no había cesado de rectificarlas y completarlas durante años. Lo seguirán siendo por otras personas y por él. La razón para sostener sus opiniones, a falta de otros argumentos, es que «sont la seule forme sous laquelle je puisse me représenter l'histoire des Livres Saints et de la religión».

${ }^{122}$ Lorenzo BeDESCHI, «Saggio introduttivo a A. Loisy... recogido en Fonti e Documenti 15 (1986), por el que citamos, 110 y 142. Hyacinthe-Marie CoRMIER, Lettre à un Étudiant en Ecriture Sainte, Fribourg (Suisse) 1905. Bernard MonTAGNES, Exégèse et obéissance. Correspondance Cormier-Lagrange (1904-1916), Paris, J. Gabalda et Cie, Éditeurs 1989. Marie-Joseph Lagrange. Une biographie critique, Paris, Cerf-Histoire 2004.

${ }^{123}$ Carta de Louis Birot a Loisy, 4 enero 1904. Birot era la persona de confianza de Mignot. Decía a Loisy: si fuera Papa, lo habría hecho cardenal y lo habtría condenado a seguir escribiendo. H. BERNARD-MAÎTRE, «Un épisode significatif du modernisme: «Histoire et dogme» de Maurice Blondel..., $72-73$.

124 «Dopo, la condanna, avevo scritto al Loisy. Egli mi rispose alcune rige molto modeste, moderate e tranquille» La misma calma reflejaba un artículo de von Hügel sobre este asunto. Fogazzaro-Bonomelli, 12 enero 1904, Antonio FogaZZARo, Lettere Scelte, a cura di Tomasso Gallarati Scotti, Milano, A. Mondadori, 1940, 522 .

125 «En écrivant que je réservais le droit de ma conscience, j'avait offensé gravement les oreilles romaines» Era un lenguaje con sabor protestante. Al no aceptar en su totalidad la sentencia, los responsables debían considerarlo una persona orgullosa. 
En la mañana del domingo 24 de enero, redactó una nueva carta al cardenal Merry del Val. El día anterior el cardenal Richard le dijo que el Papa no aceptaba su forma de adhesión a las decisiones de las dos Congregaciones romanas. Insistía en la misma razón: no podía seguir su trabajo como historiador y exegeta crítico si tenía que retractarse de todas las opiniones que hasta entonces había publicado. Declaraba ahora explícitamente que aceptaba todos los dogmas de la Iglesia. Si, contra su voluntad, sus opiniones eran contrarias a ellos, condenaba en sus escritos lo que hubiera, desde el punto de vista de la fe, reprensible ${ }^{126}$. Tenía paz entonces. Los años posteriores pudieron traicionar la memoria, la suya y la de los otros ${ }^{127}$.

La tenacidad y dureza, con las que cada parte se sentía obligada a cumplir su deber o a defender su postura, explican lo que sucede los meses posteriores. Requerido por la autoridad, insistió Loisy en que la condena del Índice y del Santo Oficio no concretaba, «et, par conséquent, il n'en condamne spécialement aucune (opinion)». ¿Se le quería obligar a condenar puntos en los que la Santa Sede había hallado errores, pero sin precisar cuáles? Ni siquiera mencionaba las opiniones que deberían ser corregidas. Descargaba así la autoridad su responsabilidad por si un día estas opiniones pudieran convertirse en verdad. ¿Por qué forzarle a emitir un juicio contra sí mismo, que la Santa Sede no se atrevía a hacer?

Se le ordenaba no seguir unas opiniones que nada afectaban a la teología. Sus libros condenados eran trabajos críticos (Etudes Évangéliques y Quatrième Évangile) o ensayos de síntesis histórica (La religion d'Israël, L'Évangile et l'Église y Autour d'un petit livre). En ninguno de ellos pretendió exponer la fe de la Iglesia, sino explicar el sentido histórico de unos textos bíblicos, la evolución histórica de las creencias y de las instituciones cristianas. Loisy continuaba exponiendo al cardenal Merry del Val su posición, y planteando unas preguntas, provocadas por la indeterminación de la condena, que afectaba a la retractación que se le pedía.

126 Alfred LoISY, Mémoires..., tome II, 313-314, 317-318 y 322.

127 En 1932, después de aparecer el tercer tomo de sus memorias, el P. Lagrange hacía suyo el testimonio de Loisy, que rectificaba lo que en 1904 dijo. En 1931 Loisy explicaba que «aceptar» era una sutil forma de eludir «creer firmemente», porque en sus escritos había rebatido «la substance de la religion». M.-J. Lagrange, Monsieur Loisy et le Modernisme..., 146-147. Este librode Lagrange es tan excusable como la rectificación de Loisy. No cuadra con su estilo esta réplica Sobre su persona, Jean GuitTon, Retrato del Padre Lagrange... y el epistolario con el P. Cormier, ya citado, y también de Bernard Montagnes, «El perfil humano y espiritual del P. Lagrange», Teología Espiritual XLIV (2000), 135-162. La postura de Lagrange en 1907 era muycercana a la de Loisy. Vid. Bernard MonTAGNES, «Marie -Joseph Lagrange frente a los teólogos hostiles a los exegetas», Anuario de Historia de la Iglesia XVI (2007), 106-112.

Hispania Sacra, LIX

120, julio-diciembre 2007, 633-706, ISSN: 0018-215-X 
¿Era inútil esa demanda? Quizás. En la Iglesia se ignoran la autonomía de la ciencia y de la conciencia de un científico. Todos son súbditos bajo el imperio de la teología, que ejerce un control absoluto. Se le quería arrojar de la Iglesia, porque el «verdadero católico» no tiene más opiniones que las de la Iglesia ${ }^{128}$. No cabe el menor disentimiento.

Decía al cardenal Merry: no podía hacer la declaración que se le había pedido. No podía retractarse de las conclusiones de sus trabajos históricos. Por eso hacía un acto de sumisión disciplinar, pero se reservaba el derecho a sostener sus opiniones, «sans les attribuer plus de certitude qu'il ne convient».

Así las cosas, a la espera de una excomunión, aconsejado por von Hügel, Loisy contemplaba la posibilidad de retirarse y trabajar en paz. Eso demostraría su moderación hacia la Iglesia. Sus intenciones eran rectas, pero no podía honestamente aceptar lo que se le exigía. Jamás había querido turbar la fe de los fieles ni agitar sus espíritus. Por todo esto, se apartaba. No esperaba obtener así la reconciliación con la Iglesia. Años más tarde dudaba que lo hubiera deseado ${ }^{129}$. «Du moins pouvais-je espérer que l'Église elle-mâme voudrait bien me laissez en paix» ${ }^{130}$.

No bastaron estas declaraciones ni su carta al Papa. Según decía el 12 de marzo Pío X al cardenal Richard, debía renunciar a los resultados de sus trabajos. Ni el Papa ni el cardenal podían entender la diferencia que Loisy establecía entre fe, teología y crítica e historia. No valían sus argumentos. Cuando comentó al cardenal que algunos miembros de la Comisión Bíblica compartían las opiniones de sus libros, Richard le dijo que las tesis de M.-J. Lagrange inquietaban.

De nada sirvió que, tras decir que todo este proceso era una contrasentido, insistiera en que sus refutadores interpretaban como tesis dogmáticas lo que eran hechos y deducciones más o menos probables en relación con ellos ${ }^{131}$.

${ }^{128}$ Después de su excomunión, defendió von Hügel a Loisy frente a lo escrito el 27 de febrero por Labanca. El profesor italiano replicó aba el 14 de marzo a von Hügel: Loisy exégesis histórica y exégesis dogmática. Eso es lícito para un exegeta libre, pero no para uno que quiera vivir en la fe católica. En este caso, su criterium crítico y su fe católica entran en contradicción. Tendrá que elegir. Loisy comentaba: «Labanca se faissait du catholicisme une idée toute romaine».

129 Después de entrevistarse el 12 de marzo con el cardenal Richard, escribió estas cuatro líneas: «Tout cela est profondément triste. Il sera fâcheux pour moi, aussi pour d'autres, que je sois chassé de l'Église, provisoirement ou définitivement. Mai il paraît bien que ma place est dehors, et qu'il n'y a plus pour moi ni sincérité, ni dignité, ni sécurité dedans».

${ }_{130}$ Alfred LoIsY, Mémoires pour servir à l'histoire religieuse de notre temps II, Paris, Émile Nourry 1931, 344-349, las citas anteriores, ibidem 359 y 369.

${ }^{131}$ La conversación la calificó Loisy como un intercambiode «discours inutiles». El cardenal no entendía más que Loisy se empeñaba en defender del control de los teólogos su independencia como historiador y exegeta, ibidem, 360-365. 
Estaba sometido a prueba. Trataba de controlar sus emociones y resistitr en silencio. El 25 de febrero de 1904 un sacerdote del «Stanislas» llevó a Loisy un artículo aparecido en Petit Temps sobre su condena. Era una entrevista a un prelado romano. Podría ser el cardenal Mathieu. Se le acusaba de haber arrojado fuera de la Iglesia a varios centenares de sacerdotes. Eso justificaba la condena de sus libros. Decidió replicar con un artículo bastante extenso «très net et très vif». Se lo entregó a Albert Houtin para que se publicara en Le Temps, pero luego se lo reclamó y renunció a su idea.

Se encontró por estas fechas con otro amigo en casa de François ThureauDangin, el P. Louis Riest, que había entrado muy joven en los marianistas y llevaba mucho tiempo destinado en el «Stanislas». Se habían conocido cuando Loisy estuvo como capellán de las dominicas en Neuilly. Era una persona inteligente, buena y muy apreciada en su Congregación. Fue superior del noviciado y profesor de teología. No era fácil salir airoso en estos cargos siendo persona penetrante y cultivada. Coincidía con Loisy en la apreciación de la teología y del cristianismo primitivo. Tuvo un papel importante para superar los problemas que creó la expulsión de las congregaciones. En 1910 desapareció «sans bruit», para no tener que hacer el juramento anti-modernista. Tenía unos cincuenta años cuando estalló la guerra. Se alistó y murió en el frente, en Crouy, a pocos kms. de Soissons el 12 de enero de $1915^{132}$.

Tras su entrevista con el cardenal Richard el 12 de marzo ${ }^{133}$, antes de regresar a Bellevue, en casa de Thureau-Dangin, redactó una breve nota, que su amigo entregaría en el arzobispado ${ }^{134}$. Este le dijo que no podía ir más lejos. Tomó entonces sus decisiones. Todas ellas las recogió en una carta privada enviada a Narfon el 2 de abril y que este publicó sin consultar a Loisy. Se retiraba de La Sorbonne por propia iniciativa. Lo hacía «en vue de la pacification des esprits dans l'Église catholique». Hizo su equipaje y se instaló en Garnay, a unos 30 kms de Chartres ${ }^{135}$. No comentaría los juicios sobre su decisión. «Tout ce que je

132 Alfred LoIsy, Mémoires..., tome II, 343 y 350. Sobre el colegio de los marianistas en París y sus conexiones con Marc Sangnier, Ambrogio AlBano, Le Sillon chez les marianistas 1894-1910, libro impreso en Varcelli y editado por los marianistas en la colección «La Gerbe» 1999. En la noticia que da sobre Riese se menciona sólo su adhesión al modernismo.

133 Cuando en 1910 Pío X condenó Le Sillon, el Papa dijo que «L’Église romaine n’a pas de coeur». Comenta Loisy, recordando su estado de ánimo en el momento en que salió del despacho del cardenal, «Je m’en étais aperçu déjà le 12 mars 1904». Alfred Loisy, Mémoires..., tome II, 366-367. La referencia a Le Sillon y Pío X, ibidem, 363.

134 «Je déclare à Votre Eminence que, par esprit d'obéissance envers le Saint-Siège, je condamne les erreurs que la Congrégation du Saint-Office a condamnées dans mes écrits».

$135 \mathrm{El} 9$ de junio anota lo que llama «règlement de l'ermitage»: 1. ninguna expectativa sobre el futuro; 2 trabajo moderado, sin prisas y sin idea de publicar mucho, aliviar el espíritu con lecturas variadas y leer sobre todo historia y literatura contemporáneas; 3 . Aire libre y ejercicio, interés en el cuidado y limpieza de la casita. Vivir en paz y alegría». Con humor ecribe: «Pie X demande impérieusement

Hispania Sacra, LIX

120, julio-diciembre 2007, 633-706, ISSN: 0018-215-X 
souhaite est qu'on me donne la paix, sans me toumenter encore», escribía el 4 de abril a Lacroix. El 2 de mayo escribió en su diario: Je traverse en ce moment une crise physique et morale de plus en plus singulières». El 10 y 12 de mayo se hallaba profundamente turbado. No sabe si su posición es honrada. Sigue en la Iglesia «pour ne pas troubler certaines âmes; mais je trouble joliment la mienne». En ese estado reflexiona sobre el credo. No cree lo que la Iglesia enseña y la Iglesia no enseñará lo que él cree. «Je vais me traîner sous l'équivoque jusqu'à la tombe».

¿Debía seguir luchando? En una carta a François Thureau-Dangin, responde el 6 e junio que nada le obliga a ello. Al revés, todo le invita a desistir de ese combate $^{136}$. La autoridad eclesiástica había acabado con su pasión por el catolicismo. Todo lo hacía en beneficio de la humanidad. El día anterior, escribió en su diario, que ni él ni Tyrrell eran ya cristianos: no creían ni en la infalibilidad del papa ni en el reino de los cielos ${ }^{137}$.

En resumen, discreción en la respuesta, intimidad en la crisis, escasamente rota con algún confidente que no le fue leal, y un secreto: «Qui perdiderit animam suam salvam faciet eam (Marc, VIII, 35)». El sufrimiento le acompañaba «de fe en fe», pero «contra toda esperanza».

El 7 de junio de 1904, Loisy escribe en su diario: No creo en la divinidad de Jesucristo. El misterio de la encarnación es un mito. En su «religión» el papel de Jesús es menor que el que tiene en el protestantismo liberal. Le da una menor importancia a su papel revelador de Dios-Padre. Y concluye: «Si je suis quelque chose en religion, c'est plutôt panthéo-positivo-humanitaire que chrétien» ${ }^{138}$. Los días cinco, seis y siete de junio de 1904 fueron sus tres jornadas agónicas.

En Lex orandi, de Tyrrell, encontraba Loisy coincidencias con sus L'Évangile e l'Église y Autour d'un petit livre. La tesis: la única forma de salvar el catolicismo es preparar su evolución, abrirlo. Estas ideas se abrirán camino. Estaba convencido de ello Loisy. Dudaba de que eso sucediera a pesar de la oposición del catolicismo oficial, «qui aimera mieux mourir immobile et isolé que de vivre en marchant avec tout le monde» 139 .

136 Quiso dejar constancia de esta conclusión en su diario. En la larga nota que escribió el 7 de junio. El 29 de junio: No erraba Comte al hablar de culto a la humanidad. Ella es para nosotros «la suprême révélation de Dieu», ibidem, 397 y 402.

${ }^{137}$ El relato de lo que llama Loisy «Les derniers jous à Bellevue», ibidem, 378-405.

138 Comentando La religion de l'avenir, de von Hartmann, un panteista, escribe:

«L'idée principale est que toutes les formes du christianisme son réellement mortes, qu'elles ne sont pas améliorables autrement qu par un changement radical et qu'il faudrait du neuf. Au fond il pense du catholicisme ce que j'en pense moi-même, ce qu'en pense Hilaie Bourdon (Tyrrell). Nous ne sommes plus chrétiens». Mémoires tome II, 395.

139 Alfred LoIsY, ibidem, 399. 
Desde hacía una semanas vivía en Garnay como un ermitaño y muy feliz. Esperaba seguir así sin que lo impidieran los actos de la Santa Sede ${ }^{140}$.

\section{EL CREYENTE Y EL CRÍTICO ${ }^{141}$}

Durante casi 20 años, Loisy volvió sobre la reacción que provocó L'Évangile et l'Église. Insistió en el carácter limitado de su texto, la honestidad de su intento, la claridad y moderación de su lenguaje y la falta de preparación de sus lectores. Le dolía especialmente la acusación de mistificación. La atribuía a la mala voluntad de unos, a la impotencia de otros para no confundir su estado de ánimo con el estado de las cuestiones.

Loisy había tocado al Nuevo Testamento, a la persona de Jesús, a los fundamentos del cristianismo. Cada cual veía dispararse la alerta en sus convicciones más íntimas y se veía incitado a definirse ${ }^{142}$.

Este requerimiento de la crítica lleva a situar la fe en la libertad, como decisión. No aceptarían eso quienes creían que la libertad nada tiene que ver con la independencia y no admitían reserva alguna respecto a la autoridad de la Iglesia en materia de fe.

Debatiendo con Harnack, puso de relieve Loisy que Cristo, su carácter y su sustancia, se han conservado el cristianismo católico, opuesto en todos sus puntos al protestantismo liberal ${ }^{143}$. «Rome (infiniment ignorante du mouvement de la critique et de ses courants, de ses tendances) crut que même une victoire sur les protestants risquerait d'être achetée trop cher». Por eso rechazó una noción de desarrollo distinta a la de sus teólogos pues la juzgaba un desastre para su idea de la ortodoxia. Su hostilidad contra L'évangile et l'Église» y contra su autor forjó la idea de que su tesis era protestante y racionalista ${ }^{144}$.

${ }^{140}$ Loisy-von Hügel, 25 septiembre 1904. Un mes antes, el 25 de agosto, escribió a su amigo Renaudin: «je doute que nos efforts servent à autre chose qu'à le rendre provisoirement plus inhabitable par la réaction qui provoque notre libéralisme Notre idéal de catholicisme est si différent de la réalité présente que nous avons l'aïr de travailler à la ruine totale de celle-ci et non à sa transformation». Ibidem, 411 y 414.

141 Comentando una convesación de Casati y von Hügel en Molveno, en agosto de 1907, Loisy dice que hay dos grandes influencia en su obra: la de Renan y la de Newman, negando la que le atribuían de Paulsen y Hébert. Ibidem, 560

142 Emile Poulat, Histoire, dogme et critique..., 117-118.

${ }^{143}$ Sea cual sea el porvenir del catolicismo, Tyrrell afirma que su pretensión de ser la tradición auténtica del cristianismo es incuestionable. Eso lo sostienen los modernistas.

144 George Tyrrell, Le christianisme à la croisée des chemins. Paris. Librairie Critique, Émile Nourry 1910, 70 y 265.

Hispania Sacra, LIX

120, julio-diciembre 2007, 633-706, ISSN: 0018-215-X 
Fue mérito de Loisy el haber centrado el debate en torno a la cristología y situarlo en el análisis de los evangelios analizados con el método histórico-crítico. En la figura de Jesús de Nazaret, tal como en ellos aparece, se hallan varios estratos. Es un hecho admitido hoy. Entonces escandalizaba, porque los teólogos romanos juzgaban que no podía separarse lo que Jesús pensaba y aquello que la primera comunidad conservó tras su muerte.

Aquí es donde hay que situar la diferencia en la interpretación de la resurrección. Los modernistas no atribuían valor al sepulcro vacío. La presencia del Resucitado, vivida en la fe, introdujo rasgos en su persona que desfiguraban los que tuvo antes de la crucifixión. Para ellos era igualmente verdadera la persona de Jesús antes y después. Había continuidad entre las dos figuras. La fe de los testigos no la había roto.

La conciencia de que Jesús vivió y anunció la inmediata llegada del Reino de Dios, destacada por Loisy, ponía en crisis la mecánica identificación entre el proyecto de Jesús y la Iglesia romana. Esto llevaba a dar prioridad al carisma, a la comunidad espiritual, a la creatividad de la plebs sancta... Esa cristología suponía una reformulación de la eclesiología ${ }^{145}$.

Cuando Loisy quiso exponer su posición, la resumió en cinco puntos: 1. El valor objetivo de la idea religiosa y moral se definen con un símbolo sensible, en eso consiste la realidad espiritual de los dogmas. 2. La partenogénesis es un caso excepcional, que ni se ha verificado como hecho real ni es verificable. Todo lo que se dice sobre María no es histórico, sino una creencia, porque no es verificable ni se ha verificado. La resurrección no puede probarse, como sucede con los dogmas relativos a María. La creación y ¡los otros casos citados son unos dogmas que se presentan como relatos. 3. Las percepciones religiosas y las fórmulas no son inmutables, porque eso supone admitir la identidad de dirección y de espíritu. ¿No ha habido una evolución en la percepción de Dios, de Cristo desde el Evangelio hasta Nicea? 4. La garantía de las creencias religiosas es la experiencia individual y colectiva de la Iglesia y en la Iglesia a través de los siglos. La experiencia crítica del historiador sobre el aspecto externo de la religión tiene su lugar o lo tendrá en esta experincia general, pero su lugar está limitado por su objeto. 5. Manifestaba su acuerdo con Tyrrell: ningún hecho religioso determina a priori un acontecimiento histórico. La historia de la religión, el conjunto de los fenómenos religiosos y hasta los otros, no tiene sentido completo más que para la fe ${ }^{146}$. Por eso ella se

145 Lorenzo Bedeschi, «Modernismo», Dizionario teologico, a cura di J.B. Bauer e C. Molari, Assisi, Cittadella Editrice 1974, 440-451, citamos por Fonti e Documenti 15 (1986), 234 y 236.

146 ¿Puede decirse que Loisy fuera un historicista? El 6 de mayo de 1905, escribió desde Garnay. Maurice Blondel quería decir siempre la última palabra. Su sistema era inadmisible: buscaba confirmar por motivos extraños a la historia hechos no demostrados históricamente o mejor no históricos por su 
convierte en la luz de la historia, «bien qu'elle ne fournisse aucune donnée particulière» 147 .

La dimensión eclesial de la fe, como recoge el número 4, obliga a la Iglesia a proteger la de los sencillos, pero ni es su deber ni tiene derecho a tratar «brutalement» las cuestiones científicas y a los hombres de ciencia. La Iglesia sabía negociar intereses más políticos que religiosos con mucho cuidado. Debería tener precauciones semejantes en los asuntos del espíritu, sobre todo en un tiempo en que la ciencia va convirtiéndose en un poder social. La legítima defensa de la fe no debe llevar a la Iglesia a desconfiar de la inteligencia y a poner barricadas contra el progreso de la ciencia.

Estas suspicacias eran ya superfluas. Una «policía» de las ideas, entendida como una vigilancia que tutela la educación religiosa de los individuos, parecía a Loisy evidente que debería actuar con unos procedimientos distintos a los que estaban en uso ${ }^{148}$. Creía más bien que el futuro de la Iglesia lo garantizaban los santos ${ }^{149}$.

Al iniciar 1906 confesaba «J'ai besoin de ma liberté, mais je n'ai pas besoin de combattre l'Église» 150 . Es significativo que no participara en Il Rinnovamento, la revista editada en Milán ${ }^{151}$.

Quiso aislarse, vivir como ermitaño, retirado. No pudo. Ni siquiera estaba a cubierto de las decisiones de Pío X en relación con la Iglesia de Francia. Formado en los años setenta, la disidencia con las decisiones romanas le creaba dudas. Vista la situación creada tras la asamblea de los obispos franceses y la encíclica de Pío X al clero de Francia ${ }^{152}$, Loisy hizo balance a finales de septiembre.

naturaleza y, por tanto, inalcanzables para un historiador. Según Bernard-Maître, estas líneas «semblent justifier Blondel d'avoir fair porter sa critique de Loisy sur le point de l'historicisme» H. BERNARD-MAîTRE, «Un épisode significatif du modernisme..., 72-73.

147 Loisy-Venard, 7 febrero 1905. Venard era el redactor de la crónica bíblica en la Revue du Clergé Français, un teólogo sutil y muy bueno. Mémoires..., tome II, 428-429.

148 Alfred Loisy-W. Ward, agradeciendo el envío d su biografía del cardenal Wiseman, 25 febrero 1905, Mémoires pour servir à l'histoire religieuse de notre temps II, Paris, Émile Nourry 1931, 430.

${ }^{149}$ Fogazzaro envió el 17 de diciembre de 1905 a Loisy un ejemplar de Il Santo. A pesar de no conocer bien el italiano, confiesa haberlo leído fascinado. Le habían emocionado muchas escenas. «Souhaitons que votre saint, suivi de plusieurs autres, existent bientôt ailleurs que dans le roman». Estaba seguro de que esta obra había servido noblemente a la causa de la Iglesia y de la verdad. LoisyAntonio Fogazzaro, Garnay 17 didiembre 1905 y 4 febrero 1904, en Maurilio GuAsco, «Loisy e i Lombardi», Fonti e Documenti 2 (1973), 618.

${ }^{150}$ Diario 9 enero 1906, Mémoires..., tome II, 461.

151 Junto a los católicos que la inciairon y dirigieron, estaban los barnabitas Pietro Gazzola y, Giovanni Semeria, a quien Salvatore Minocchi llamó «il direttore spirituale» y Frederich von Hügel. A través de ellos aparece en la revista el influjo de Loisy, que no llegó a colaborar. «Carteggio Alfieri-Sabatier (Carte Sabatier alla Maisonnette)», a cura di Lorenzo Bedeschi, Fonti e Documenti 2 (1973), 95.

152 «Vehementer Nos», 11 febrero 1906. Versión franaces e inglesa enhttp://www.vatican.va/ holy_father/pius_x/encyclicals/index_sp.htm

Hispania Sacra, LIX

120, julio-diciembre 2007, 633-706, ISSN: 0018-215-X 
Sus reflexiones de esas semanas le llevaban a concluir que su actitud era «de plus en plus une comédie». Sus sentimientos denunciaban que había dejado de ser católico. Siendo sacerdote, su deber era abandonar la Iglesia. Acababa de solicitar al obispo de Chartres la autorización para celebrar en privado. Estaba angustiado. El 1 de noviembre, escribía: quizás me aguarden una vejez y una muerte muy tristes, después de haber buscado el reino de Dios y su justicia. Si me he equivocado no tengo derecho ni al resentimiento ni a la amargura. Esperaba sólo que sus sufrimientos fueran «pour le compte de l'humanité» y sus vivir tranquilos sus días finales ${ }^{153}$.

En enero de 1907 estaba mal de salud. Recurrió a su amigo, Alfred Houtin, para que corregiera las pruebas de Les Évangiles Synoptiques y cuidara su edición, si fallecía antes de que todo estuviera hecho. Le entregó también sus notas para que redactara una noticia necrológica ${ }^{154}$. Redactó en marzo el esquema de un libro, Régime intellectuel du catholicisme et les fondements de la foi. Hablaría de tres cuestiones: la libertad, la verdad y Dios, Esta cuestión entendida como fe. Se preguntaría luego por la función de la Iglesia y qué queda del símbolo católico. Este nuevo «petit livre» era fruto de su sufrimiento, de una experiencia muchas veces llena de tristeza. Al iniciarlo duda si podría terminarlo. Lo había hecho de cara a la eternidad, como un testamento, con la sinceridad que se pide a quienes se acercan a la muerte.

«Je soumets ces humbles pages au jugement de l'Église à venir; je, Loisy dédie a tous les enfants de Dieu, a tous ceux qui ont et qui auront au cœur de réaliser la vérité dans la charité».

Un hecho venía a confirmar que ese porvenir de la Iglesia no estaba próximo. El 29 de abril de 1907 el cardenal Steinhuber, el jesuita prefecto del Índice, escribió al cardenal de Milán. Censuraba en toda regla a los redactores de Il Rinnovamento, a quienes se designaba como «soi-disant catholiques». Actuaban como si fueran maestros y doctores en la Iglesia. Hablaban con arrogancia de las cuestiones teológicas más difíciles y de asuntos importantes en la vida de la Iglesia. Lo hacían proclamando que su revista era laica y no confesional. Distinguían entre el catolicismo oficial y no oficial, entre los dogmas definidos como verdades y la inmanencia de la religión en el individuo. Libres ante la autoridad de la Iglesia, ante su magisterio, hacían prevalecer su juicio sobre el de aquel. Con todo eso proyectaban una renovación anticatólica de los espíritus.

${ }^{153}$ Alfred Loisy, Mémoires..., tome II, 485 y 491.

154 Pasado el tiempo, Loisy lamentó que aquel signo de amistad fuera usado como material para publicaciones «difamatorias». Vid. Mémoires..., tome II, 512. 
No se doblegaron los redactores que defendieron su derecho a seguir sus investigaciones científico-religiosas y pedían tiempo para que pudiera juzgarse con justicia sus intenciones. En el grupo estaban todos los «amigos», Fogazzaro, Tyrrell, von Hügel, Murri, Alfieri, Casati, Gallarati Scotti. No se incluía en la carta a Loisy, porque no era redactor.

En una carta del 10 de mayo a von Hügel, descalificaba la retórica usada por el cardenal Steinhuber. Esas palabras injuriosas no disminuirían la estima que hacia su persona tenían todos los que lo conocian. Sabían que era «le meilleur et les plus humbles des hommes, et le plus dévoué des amis». Dos días mas tarde, en su carta al cardenal, decía que «la mention à von Hügel, dans les conditions ou Votre Éminence a cru devoir la faire, restera comme une injure gratuite, qui pèsera sur qui la lancée, non sur qui la reçue» ${ }^{155}$.

\section{EXCOMMUNICATUS VITANDUS}

Se creyó aludido en las palabras de Pío X a los nuevos cardenales en el consistorio del 17 de abril. ¿Quienes eran los modernistas? Unos rebeldes. Bajo formas engañosas, profesaban y difundían «errori mostruosi» sobre la evolución del dogma, el retorno al evangelio puro, despojado de las explicaciones de la teología, de las definiciones de los concilios, de los principios ascéticos. En cuanto a la disciplina, propugnaban la emancipación de la Iglesia, pero de forma original «per non esser tagliati fuori ma nemmeno assogettarsi per non mancare alle proprie convinzioni». Su adaptación total a los tiempos presentes en su manera de hablar y escribir y «nel predicare una carità senza fede, tenera assai per i miscredenti, che apre a tutti purtroppo la via all'eterna rovina».

El modernismo no era una herejía. sino «il compendio e il veleno di tutte le eresie. che tende a scalzare i fondamenti della fede ed annientare il cristianesimo». No era esta afirmación exagerada, pues los modernistas rebajaban la biblia a la categoría de unos escritos humanos. La inspiración se reducía a las cosas de fe. En su interpretación, la Iglesia debía someterse a las exigencias de la ciencia crítica. Las tradiciones de la Iglesia también seguían las leyes de la evolución. De ese modo destruían la autoridad de los Santos Padres.

Para difundir estas teorías usaban folletos, libros, revistas y hasta novelas. Encubrían sus pensamientos en fórmulas ambiguas, que les permitían librarse de una censura y engañar a los incautos.

Todos los obispos, en cuanto conocieran la existencia de estos «sembradores de cizaña», se deberían al Papa para luchar contra ellos, denunciarlos a la Santa

155 Diario, 17 marzo 1907. Alfred LoIsy, ibidem, 513. La carta a von Hügel, ibidem, 520 y 524.

Hispania Sacra, LIX

120, julio-diciembre 2007, 633-706, ISSN: 0018-215-X 
Sede y condenarlos con la autoridad que les reconocían la legislación canónica, «persuasi dell'obbligo altissimo che avete asunto di aiutare il Papa nel governo della Chiesa, di combattere l'errore e di difendere la verità fino all'effusione del sangre» 156 .

Envió una «humble rectification». Lo hacía en conciencia y como acusado y dirigida a la conciencia de su acusador. Las palabras públicas de un Papa no se pronuncian a la ligera. Había que examinar y examinarse para que quienes son objeto de esas quejas ajustaran su actitud, teniéndolas presentes. Consideraba igualmente un deber de justicia no callar. Si los encausados creen que las imputaciones no son proporcionadas a los hechos, el Papa debe conocer los sentimientos verdaderos, las palabras y los actos de aquellos a quienes se ha visto obligado a denunciar.

La palabra «rebeldes», según los llama el Papa, no es aplicable más que los protestantes que predican el «regreso al evangelio puro». ¿Hay alguien entre los que parece señalar el Papa que haya valorado el desarrollo cristiano como una «floración» que necesitara podarse para restituir al evangelio su pureza original? Loisy decía que había tratado de refutar en su obra L'Évangile et l'Église esta tesis de Harnack. Nadie podía decir que era suya, pues la había combatido siempre. Es cierto que también había escrito que las formas de desarrollo católico nada tienen de absoluto y, por tanto, el dogma, el gobierno e incluso el culto son perfectibles. Nada que sea malo en sí puede mejorarse. Si hubiese pensado Loisy que la teología, los concilios, el ascetismo contradecían el evangelio, jamás hubiera defendido la concepción católica frente a la concepción protestante. No hubiera juzgado al catolicismo capaz de progreso y de rectificación.

Jamás había sostenido ni escrito que la inspiración bíblica se limitaba a cuestiones fe y costumbres, ni que la Iglesia, al interpretar las Escrituras estaba sujeta a las normas de la ciencia crítica. Había escrito todo lo contrario, reconociendo en la totalidad de la enseñanza de la Biblia y de la Iglesia un elemento o un aspecto relativo y variable, cuya existencia no puede discutirse, salvo por quienes jamás han estudiado la Biblia y el magisterio en su historia.

Dolía a Loisy que Pío X hubiera citado con amargura a quienes se emancipan de la Iglesia, sin declararse en rebeldía, porque no quieren ser expulsados de ella, pero no se sometían y renegaban de sus propias convicciones. La Congregación del Santo Oficio y del Índice había condenado sus libros en diciembre de 1903. Le pidieron entonces una retractación tan amplia, que le resultó imposible hacerla. Esa exigencia superaba en mucho el juicio emitido sobre unos libros. El Santo Oficio no condenada ninguna tesis en concreto. Eran tex-

156 Texto original, Acta Apostolicae Sedis 40 (1907), 267-269 y Doctrina Pontificia. I Documentos Bíblicos..., 276-278. 
tos en los que había expuesto sus opiniones, la mayoría de índole histórica, es decir que escapaban al juicio de la Iglesia.

«Mes sentiments n'ont pas changé depuis trois ans. Mais il serait faux et injuste dire que je ne me suis pas révolté, par ce que j'ai craint d'être mis au dehors. Je ne me suis pas révolté, par ce que je n'avais pas aucun motif de conscience pour rompre avec l'Église, et que je pensais d'avoir de ces motifs pour rester dans la profession du catholicisme». Las amenazas no habían determinado su comportamiento. Aunque no hubieran comprendido su conducta, no lamentaba los sacrificios hechos esos tres años porque juzgaba que cooperaba así en la pacificación de los espíritus ${ }^{157}$. La situación no mejoró con esta carta, una especie de derecho de petición, de audiencia. Inmediatamente comenzó un proceso contra él ${ }^{158}$.

Varias de las proposiones sobre la revelación, condenadas en el decreto Lamentabile sane estaban extractadas de las 33 recogidas por la comisión creada por el cardenal François Richard ${ }^{159}$.

El 4 de julio de 1907 Pío X lo sancionó. La introducción revela la visión del Papa sobre su tiempo. Tiene 65 proposiciones. Todas ellas caen bajo la consideración de «errores muy graves», que alteran el dogma con el pretexto de interpretar la Escritura y los misterios de la fe, usando los criterios de la crítica y de la historia.

Pío X canonizaba la teología y una visión inmutable de la fe. Había varias incógnitas: las proposiciones condenadas ¿eran erróneas o heréticas? ¿Era el documento una decisión magisterial ordinaria o infalible? En ambos casos obligaba en conciencia, pero en el primero cabía la posibilidad de una duda razonable sobre la total falsedad de las proposiciones condenadas.

Sabía Loisy que esta distinciones era meramente especulativa, porque Roma no aceptaba que se discutiera lo que ella decía. Incluso aunque algunas fueran verdaderas provisionalmente deberían juzgarse falsas, porque así lo establecía la autoridad.

157 Alfred Loisy-Merry del Val, Ceffonds, 12 mai 1907, ASV SS 82 (1908) 8 148-149. La doblez de los modernistas fue uno de los motivos más presentes en los mensajes dirigidos a Pío X. Los modernistas replicaban a las críticas y a las advertencias con sutilezas y un atrevimiento cada días mayor. Vid los mensajes enviados por los obispos de Nancy et de Toul y Poitier, Charles François Turinaz y Henri Pelgé, 17 y 19 de septiembre, ibidem, 9 50-54.

158 Esa fue la respuesta del cardenal. Merry del Val-Asesor del Santo Oficio, 15 de mayo. Cartas de Loisy a Roussel, redactor jefe de L'Univers. Merry del Val-Asesor del Santo Oficio, 30 de octubre, ibidem, 150-151. No fueron publicadas porque el director lo impidió. Nota marginal, ibidem, 159.

159 Roger AuberT, «Aux origines de la réactions antimoderniste. Deux Documents inédits», Ephemerides Theologicae Lovanienses XXXVII (1961) 563-567. El texto latino de las 33 proposiones, ibidem, 572-578.

Hispania Sacra, LIX

120, julio-diciembre 2007, 633-706, ISSN: 0018-215-X 
Respondiendo a Alfred Baudrillart, Loisy sostuvo que el decreto condenaba opiniones que podrían deducirse de los escritos de algunos autores o de opiniones sostenidas por ellos. No era una versión correcta de lo dicho o escrito, Parecía que se buscaba condenar, sin detenerse a examinar si las proposiciones recogidas alteraban el sentido de las opiniones que se rechazaban como errores. Eso concluyó Loisy respecto a las proposiciones sacadas de sus obras ${ }^{160}$.

Se colmó esta impresión cuando el 8 de septiembre de 1907 apareció la Pascendi Dominici Gregis. Loisy fue tajante: el documento del Papa era una hipocresía. Había creado una doctrina que nadie sostenía ${ }^{161}$. Ignoraba Loisy que su carta del 12 de mayo al cardenal Merry del Val desencadenó la decisión de excomulgarlo. Cuando volvió a escribirle el 29 de septiembre ${ }^{162}$ le extrañó que no lo hubieran echado de la Iglesia. Pensaba que era una medida retardada para presentarlo como un «obstinado». ¿Buscaba Loisy «provoquer l'excommunication personnelle», tal como denunció Albert Houtin? ${ }^{163}$ La cautela es el estilo de la Santa Sede. No iba a precipitarse. ¿Se podía detener la corriente de ideas en la que se insertaban los escritos de Loisy? ${ }^{164}$.

Friedrich von Hügel acababa de leer la Pascendi. Estaba de acuerdo con Loisy. Su parte teórica desarrollaba un sistema simulado en gran medida. Ningún modernista estaría obligado a desmentirlo, porque jamás se había enseñado eso. La parte práctica, lo que se decía sobre la persona, la obra y las intenciones de los modernistas, era un anuncio: el Papa juzgaba a los modernistas orgullosos y pérfidos. Deseaba que todo el mundo se alejara de ellos como de la peste. Se preguntaba Loisy por qué el Papa no los había ya excomulgado, puesto que no podría esperar que se sometieran. No era necesario, decía, pues «...je considère cette solennelle diffamation comme une censure définitive et je prends mes mesures en conséquence»165.

${ }^{160}$ Lo denunció en su respuesta al cardenal Merry del Val el 19 de enero de 1908, Alfred LoISY, Mémoires pour servir à l'histoire religieuse de notre temps II, Paris, Émile Nourry 1931, 545, 550 y 609.

161 Vid. Mémoires..., tome II, 590-591.

162 Esta correspodnencia fue publicada. Quelques lettres sur des questions actuelles et sur les événements récents, chez l'auteur, 1908.

163 Francesco TuRVAsi, The Condemnation of Alfred Loisy and the historical Method, Roma, Edizioni di Storia e Letteratura 1979, 204.

164 La extrañeza del P. Vigouroux por esa actitud, en una carta del 26 de enero de 1903, comentando la condena por parte del cardenal Richard, Roger AUBERT, «Aux origines de la réactions antimoderniste. Deux Documents inédits..., 571-572.

165 Albert Houtin et Félix Sartiaux, Alfred Loisy. Sa vie, Son oeuvre..., 144. Sobre la excomunión, ibidem, 141-156. Texto francés, ibidem, 151. 
La encíclica se inventaba un sistema porque tal como era descrito, nadie lo exponía ni defendía ${ }^{166}$. La primera consecuencia fue la creación de una «police inquisitoriale qui sévit encore l'Église catholique au moins dans certains pays, notamment en France et en Italie»

La descripción del agnosticismo era un mal resumen de las ideas de Blondel y de Labertonnière, personas creyentes, que no situaban a Dios en el terreno de lo incognoscible. Nada tenía que ver la exégesis de Loisy con el agnosticismo.

Casi oculta en el texto, la intención de la encíclica era ser un acto solemne del magisterio del Papa, pero se quedó en un «pamphlet animoderniste». Fue además un error de cálculo. El modernismo no era la doctrina de un grupo, sino la tendencia de una multitud. Los considerados modernistas presentaban sus conclusiones con reservas y matices, de modo que para identificarlos hubo que engordarlas. Ese grupo no quería innovar, sino permitir, gracias una mayor apertura, que se discutieran los problemas. No eran los actores de un complot, sino gentes de buena fe que deseaban poner su inteligencia y su voluntad para solucionar las dificultades de la Iglesia ${ }^{167}$.

Cuando se conoce la «Redaktiongeschichte» del documento de Pío X, se ve que no les fue fácil descubrir a Loisy y Frederich von Hügel su estructura interna y su intención. Como posibles autores se citó a Umberto Benigni, que habría actuado como ayudante de Louis Billot. Benigni lo desmintió en 1908 en una entrevista con dos periodistas franceses. Era más creíble la atribución a Billot, por sus conocimientos, por su condición de profesor de la Gregoriana, de francés y por su estilo ${ }^{168}$. Cuando murió después de haber sido cardenal y de haber renunciado, la Action Française tuvo interés en resaltar su participación en la encíclica. Era, decían, «un dialecticien extraordinaire, un merveilleux maître de discipline intellectuelle. Il possédait la scholastique comme peut-être aucun». A Billot se le habría asociado el P. Mattiusi, que le sucedió en la Gregoriana.

166 En dos estudios aparecidos en el 2007, hay un desacuerdo entre quienes aceptan quen el modernismo era un sistema, que puede ordenarse en sus diferentes versiones, y quienes creen que era un movimiento que desemboca en una crisis, buscando en él, tanto su geografía como las diferencias entre los mismos modernistas a partir de la distinción entre movimiento, actitud y crisis. En la primera posición, Santiago CASAS, «En recuerdo de la crisis modernista a la vuelta de un siglo», Anuario de Historia de la Iglesia XVI (2007), 27-30. En la segunda, César IzQuiERdo, «Cómo se ha entendido el «modernismo teológico». Discusión historiográfica», ibidem, 63.

167 Simples réflexions sur le décret du Saint-Office «lamentabile sane exitu» et su l'encyclique «Pascendi Dominici gregis», Chez l'auteur, Ceffonds 1908, 279 y 2eme ed. 1908, 257-258. He tratado este asunto en «La Pascendi dominici gregis (1907) vista desde los modernistas». qua aparecerá en Anthologica Anпua.

168 Sin embargo esto no impidió que los jesuitas de la Gregoriana estuvieran bajo sospecha: Cfr. Giacomo Martina, Storia della Compagnia di Gesù in Italia. (1814-1983), Brescia, Morcellina 2003, 218-223.

Hispania Sacra, LIX

120, julio-diciembre 2007, 633-706, ISSN: 0018-215-X 
La otra persona que hizo el trabajo fue Joseph Lemius, de los Oblatos de María Inmaculada. Era una persona bien vista en la Curia y que había estado trabajando sobre lo que vertebraba los escritos de las personas que abogaban por una renovación y por reformas dentro de la Iglesia y de la teología.

En 1937, François Veuillot vio confirmada esta hipótesis. L'abbé Castagnet había sido asesorado por Lemius en Roma, mientras preparada su tesis. Fue Lemius quien le resolvió algunas dificultades que tenía respecto a Loisy. Cuando leyó la Pascendi, Castagnet reconoció palabra por palabra lo que Lemius le había dicho. Esa impresión se la confirmó en 1938 Jean-Batiste Lemius, hermano de Joseph y también oblato. Este fue su relato. Llamado por Merry del Val, aceptó el encargo. Cuando lo terminó, su texto, gustó al Papa. Cuando se publicó, Pío X regaló al P. Lemius una medalla de oro de su pontificado.

Jean Rivière publicó esta noticia. A. Perbal, oblato, le escribió el 9 de diciembre de 1946 rectificando los detalles más «edificantes». Merry del Val llamó al P. Lemius, porque era conocido del cardenal Oreglia di Santo Stefano. Mgr. Tampieri que fue secretario del cardenal y luego su vicario cuando el cardenal fue obispo suburbicario de Ostia, trabajaba desde 1904 en la congregación de Affari Ecclesiastici Straordinari. Fue quien habló a Merry del Val de Lemius. Se le entregaron varios esquemas. Trabajó a tiempo completo varios días, no una sola noche, como había dicho Rivière. Esta última versión fue rectificada por otra del P. Centurion, oblato, escrita el 31 de diciembre. El P. Lemius dijo que había redactado la refutación del modernismo. Creía que los principios generales recogidos eran obra de Billot ${ }^{169}$.

Volvamos a Loisy y asus amigos. El 3 de octubre respondía Mignot a Loisy. La parte práctica de la encíclica abría la puerta a las delaciones. Así pasó. No se realizó, en cambio, el anunciado proyecto de agrupar a los sabios católicos para que, teniendo como guía la verdad católica, hicieran progresar la ciencia y la erudición. Era una quimera. Los sabios católicos sabían que la ciencia no es confesional, que no era viable una ciencia católica controlada por la teología oficial. Una futura Academia Católica sería ocupada por falsos sabios que la desprestigiarían. El proyecto cayó sin ruido y eso le ahorró el ridículo.

Loisy juzga necesario comentar este hecho: existen límites a la omnipotencia pontificia, a la tiranía de los teólogos, incluso en la Iglesia que se funda «sur le

169 Lemius escribió luego un catecismo, traducido en 1908 al italiano y al español por dos religiosos de su congregación. Martina insiste en la aportación importante hecha por el P. Billot, creado cardenal en 1911. Jean RIVIÈRE, «Qui redigea 1'enciclyque «Pascendi»?», Bulletin de Littérature Ecclésiastique XLVII (1946) 143-161, 242-243. Sobre este mismo asunto, Antoni BorRÀs I FELIU, «Filosofía-teologia en el plateig modernista», Analecta Sacra Tarraconensia XLIV/1 (1974), 155. Confunde a Joseph Lemius con su hermano Jean-Baptiste, de la misma congregación. 
principe de cette omnipotence et qui affirme le droit divin de cette tyrannie» ${ }^{170}$. Parece demasiado sumario este juicio, incluso para aquel momento y aquel acto. ¿Lo era? Loisy, tras estudiar la Biblia como un documento y habiendo llegado, en el curso de su labor, a conclusiones que la Iglesia no admitía, por ser contrarias a la ortodoxia, criticó esta noción. Era insostenible y sin sentido. Los modernistas, que permanecieron en la Iglesia siendo modernistas, no quisieron hacer lo mismo ${ }^{171}$.

En cierto sentido la ortodoxia es la madre de la herejía. La recíproca también es verdadera, «car l'orthodoxie est un mythe». Las doctrinas evolucionan. Cuando una es rebatida o evoluciona o perece. La ortodoxia de mañana no será la de ayer, sino un «produit croisé de de cette orthodoxie et de l'hérésie d'aujourd'hui». El cristianismo tradicional se ha fundado sobre el mito de la ortodoxia. Ese mito no le ha favorecido. Es una ilusión de la teología afirmar que es inmutable algo que varía, que jamás ha acabado de fijar sus límites y que cambia continuamente.

Esta convicción la hallaba Loisy ya en sus notas de 1884. Entonces tenía claro el valor relativo de todas las teorías generales de la teología y de la ciencia. Esa imperfección les permite avanzar, porque las hace perfectibles. «Nous allons retrouver cette idée dans ma thèse «De divina Scripturarum inspiratione; nous la retrouverons dans l'Évangile et l'Église, puis dans le livre La Religion et dans mes plus récentes publications». Por eso en 1889 sabía que la ortodoxia era una mera ilusión, que solo existe en la imaginación de quienes creen en ella. Difícilmente podría ser para él una barrera que le impidiera su trabajo crítico. Creía que el destino de todos los dogmatismo era ser derribados por la verdad ${ }^{172}$.

En diciembre de 1907 se aceleró el proceso contra Loisy. Intervinieron como consultores del Santo Oficio Van Rossum, Langogne y Palmieri. Juntos redactaron las conclusiones. La excomunión debería basarse en un hecho actual. No servían las declaraciones de Loisy a Roussel, porque eran anteriores al decreto Lamentabili y a la encíclica Pascendi, no estaban destinadas a la publicidad y se limitaban a una controversia con un periodista. No podía decirse que Loisy fuera un «obstinado», pues esos escritos no habían sido examinados previamente por la Santa Sede. Habían sido redactados antes de la encíclica y del decreto y no había constancia de oposición a la Santa Sede. La carta de Loisy al cardenal Merry tampoco podría usarse para justificar la excomunión. Estaba «piena di eresie» y redactada con soberbia, pero era un acto privado.

170 Alfred LoIsy, Mémoires..., tome II, 565-586. Erró al atribuir a Billot y a Benigni la redacción y creyendo que Billot fue creado cardenal el 11 de noviembre de 1911 como premio. Pensaba que, en ningún caso puede disminuirse la responsabilidad plena del Papa.

171 Une oeuvre clandestine d'Henry Bremond. Sylvain Lebrand, Un Clerc qui n'a pas trahi. Alfred Loisy d'après ses mémoires. 1931, édition critique et dossier histórique par Émile Poulat, Edizioni di Storia e Letteratura, Roma 1972, 146.

172 Alfred Loisy, Mémoires..., tome I, 35, 126, 176 y 179.

Hispania Sacra, LIX

120, julio-diciembre 2007, 633-706, ISSN: 0018-215-X 
Lo tres consultores juzgaban un deber que se escribiera al obispo de Loisy para que este rectificara e hiciera acto de sumisión plena, que debería publicarse, como reparación al escándalo dado. La retractación debería afirmar que condenaba, sin restricción alguna, todas y cada una de las proposiciones del decreto Lamentabili, tal como las condena la Iglesia, y condenaba asimismo el modernismo, tal como lo hace la encíclica. Se le prohibiría volver a publicar nada ${ }^{173}$.

Inmediatamente se escribió al obispo de Langres, utilizando como intermediario a Charles Gibier, obispo de Versalles ${ }^{174}$. Las condiciones que le impusieron a Loisy en enero de 1908 eran más duras que las de 1904. Concluyó, por tanto, que en Roma esperaban retenerlo dentro de esta especie de cautividad $^{175}$. No lo aceptaría ${ }^{176}$. Antes de proceder a la excomunión, los cardenales del Santo Oficio creyeron oportuno que el obispo de Langres repitiera su gestión, anunciando la pena canónica que pendía sobre Loisy. Así se hizo $^{177}$.

Las obras de Loisy tenían resonancia entre los intelectuales, escasa en el clero y nula entre los fieles. Con todo, su empeño por permanecer en la Iglesia lo convertía en un peligro para la «foi des faibles», según Herscher, el obispo de Langres $^{178}$.

El 19 de febrero de 1908, anunció Loisy a los lectores del Bulletin de'histoire et de litterature réligieuses, en su número de cierre, que se retiraba. Escribió a Maude H. Petre sobre su postura, desmintiendo algunas cosas aparecidas en la prensa. Sus ideas eran las expuestas en sus libros, no las que le atribuían los periodistas.

173 «Se si sottomette, abbiamo guadagnato un'anima. Se non si sottomette, come è da temersi, si può, senza che abbia da lagnarsi, procedere alla dolorosa recione di un membro morto». Copia de este parecer, emitido el 29 de diciembre y aprobado por el Papa el 5 de diciembre, fue enviado al cardenal Merry el día siguiente, ASV SS 82 (1908) 8, 158-159.

${ }^{174}$ Merry-Gibier y Gibier-obispo de Langres, 9 de diciembre y sin fecha y acuse de recibo y aceptación de la misión por parte del obispo de Langres, ibidem, 162-167.

175 Pasados los años, Loisy trata de explicarse la reacción de Tyrrell, tan distinta de la suya. Tyrrell se sublevaba contra el absolutismo romano, porque aún se apasionaba por los intereses de la religión católica. No era ese su caso. Los asuntos de la Iglesia «ne me touchaient plus» Mémoires..., tome II, 610-611.

${ }^{176}$ Así lo transmitía el cardenal Merry al Santo Oficio el 26 de enero de 1908., Herscher, obispo de Langres recibió la negativa de Loisy el 19 de enero, ASV SS 82 (1908) 8168 y 174. Loisy publicó esos días Les évangiles synoptiques y Simples réflexions sur les Décret Lamentabili sane exitu et l'encyclique Pascendi Dominici Gregis, ambas editadas en Ceffonds, a donde había fijado su residencia.

177 Respuesta del Santo Oficio y carta del cardenal Merry a Sébatien Herscher, 18 y 19 de febrero, ASV SS 82 (1908) 8, 172-173.

178 Herscher-Merry del Val, 17 de febrero, ibidem, 174-175. Ese mismo día firmaba una «Ordenance» episcopal declarando heréticas las dos obras que acababan de aparecer en Ceffonds. 
La distinción entre ciencia y fe era real, esencial. A veces había acentuado esa diferencia para levantar un baluarte ante las pretensiones de los teólogos. Quería dejar claro que sus últimos escritos no habían modificado su actitud hacia la Iglesia. Su comentario a los sinópticos era una obra de «pure science». Le había dedicado quince años. La publicación nada tenia que ver con los recientes documentos y actos de la Santa Sede. Sus «réflexions» no son rebelión, sino una explicación sincera. Tenía derecho a hacerla, «puisque tout le monde sait que j'étais visé dans une bonne partie du décret Lamentabile et de l'encyclique Pascendi» ${ }^{179}$.

El 7 de marzo era excomulgado porque «plura et verbo docuisse et scripto in vulgus edidi quae ipsamet fidei christianae potissima fundamenta subvertunt» ${ }^{180}$. El decreto insiste en que todos reconocen que sus enseñanzas arruinan los fundamentos de la fe cristiana. La esperanza de que rectificara no se había cumplido, al no adherirse a las recientes enseñanzas del Papa. Sus nuevos escritos, aparecidos tras esos actos, confirmaban su obstinación. Esa obstinata contumacia obligaba a pronunciar una excomunión mayor, declarando que estaba Loisy afectado por todas las penas aplicadas los excomulgados públicos. Era, por tanto, vitandus ${ }^{181}$.

Tenía cincuenta y un años cumplidos. Se sentía cansado y físicamente desgastado, como le confirmaron los médicos. Decidió retirarse a Ceffonds, cerca de su familia. «Je n'attendais plus rien de la vie, et si l'excommunication me rendait la liberté, elle ne m'apportait aucun espoir de situation ou d'action dans la société contemporaine». Sólo necesitaba independencia para trabajar y paz para morir tranquilo ${ }^{182}$.

El 26 de marzo de 1908 escribió a Houtin. En 1904 aún creía que la Santa Sede no deseaba exterminar la crítica histórica. Por eso pudo aceptar una fórmula de conciliación, que, en modo alguno, lo comprometía a entender los dogmas de la misma manera que la enseñanza oficial de la Iglesia. En su declaración de entonces se reservó la libertad de su conciencia y de su trabajo científico.

La Iglesia iba hacia la reacción. Loisy confesaba haber caminado hacia la libertad. Cuanto mayor era la oposición de la Santa Sede al movimiento de la

179 Alfred Loisy, Mémoires..., tome II, 627-630.

180 Se transmitió el mismo 7 de marzo al cardenal secretario de Estado, al obispo de Langres y a Léon A. Amette, arzobispo de París el 14 de marzo, ASV SS 82 (1908) 8, 179-187. Fue publicado este decreto en L'Osservatore Romano 58 (8 marzo 1908) 1.

181 Texto y comentario breve, Mémoires..., tome II, 642-643.

182 «Nous voici encore au tournant d'une année. Celle que nous venons de coir a commencé par un gros orage et finit dans un calme relatif. Espérons que celle qui nous arrive nous affermira de plus en plus dans la paix» Loisy-von Hügel, 27 diciembre 1908.

Hispania Sacra, LIX

120, julio-diciembre 2007, 633-706, ISSN: 0018-215-X 
ciencia, al progreso de la civilización, al mantenimiento del progreso de la religión en Francia, más crecía su deseo de defender su libertad. La conducta de Roma ante la Ley de Separación y los actos de 1907 se sumaron a la negativa del indulto para poder celebrar. Lo había pedido sin mucha convicción, pero con ese acto quedabar resuelta su situación ${ }^{183}$. Era el final lógico de todo lo sucedido desde $1903^{184}$.

Casi todas las muestras de apoyo que recibió se parecían a la de von Hügel: creían en el futuro del modernismo dentro del catolicismo. No quiso pronunciarse sobre esa certeza. Pasado el tiempo decidió concluir el volumen II de sus Mémoires citando a un joven pastor protestante, que le escribió el 5 de junio de 1908: «Je ne sais si je comprend le signes des temps, mais je crois que, pour le protestantisme comme pour le catholicisme, l'idéal, c'est disparaître pour céder la place à quelque chose qui vaudra mieux que catholicisme et protestantisme»185. Esos mismos días había recibido Fogazzaro Les Évangiles synoptiques, editados en Paris por Nourry. No los había leído. Una primera ojeada le llevaba a la convicción de que las grandes líneas de la verdad escapan al método histórico. No basta con demoler. Muchas de las conclusiones, decía a su amigo Gallarati Scotti, parecían tomas de posición previas. Estaba Fogazazaro con quienes criticaban este «metodo della lente» ${ }^{186}$.

¿Esperaba Roma que no soportara Loisy su excomunión mayor y que se prestara a un arreglo? Parecía que sí. El nuevo obispo de Châlons lo citó. Era una llamada no «malveillante». Eso decía el cardenal Luçon, arzobispo de Reims. Le hizo llegar esta observación a través de Renaudin, cura de Saint-Alpin, que le escribió el 17 de marzo. Pío X deseaba sinceramente la conciliación, pero no se daba cuenta de su alcance y, por eso, ponía unas condiciones inacep-

183 «Il me semblait, et je crois encore, que si l'on franchit les limites des croyances chrétiennes, on n'es plus chrétien, et si l'on franchit les limites du catholicisme romain, on n'est plus catholique romain, le caractère commun des sectes chrétiennes et de l'Église romaine ayant toujours été, au lieu de s'élargir et de s'approfondir, de se limiter en se définissant»

184 Alfred LoISY, Mémoires pour servir à l'histoire religieuse de notre temps, Tome Troisième 1908-1927, Paris, Émile Nourry, Éditeur, 1931, 5 y 13-15. La carta a von Hügel, ibidem, 73

185 Alfred LoIsY, Mémoires pour servir à l'histoire religieuse de notre temps II, Paris, Émile Nourry 1931,651 .

${ }^{186}$ Había comentado con von Hügel lo que le molestaba en la obra de Loisy, Fogazzaro-Gallarati Scotti, 22 marzo 1908, en Antonio FogazzAro, Lettere Scelte..., 630. Decía el 1 de abril a Bonomelli que Loisy se había situado fuera de la Iglesia no sólo por negar la divinidad de Cristo, sino también por su método exegético. Con él ponía de relieve todo lo que hay en los evangelios que atacban la fe en los evangelios, un terreno diferente al de las ciencias físicas. Esperaba que est explicación de lo que pensaba dejara satisfecho al obispo, ibidem, 631-632. 
tables. A cambio de un poco de paz, la oferta era «le néant de la pensée, néant de la consciente, néant de l'action» 187 .

El modernismo estaba en ruinas. Duraría poco tiempo. Respondió a Loisy Frederich von Hügel el 7 de noviembre que el nuevo Papa no aceptará la crítica sobre la Biblia, pero cabía una conciliación «en cent ans d'ici». Loisy creía que su amigo no se daba cuenta que esa idea estaba ya condenada por Pío X. Un católico debe aceptar sin reserva alguna y sólo basado en el testimonio de la Iglesia, todo lo que ella enseña como «verdad inmutable» 188 .

Eso mismo pensaba George Tyrrell. En el otoño de 1908, el editor inglés de L'Évangile et l'Église creyó que mejorarían las ventas con un prólogo suyo. En él afirma que Loisy no pasará a la historia como crítico de la Biblia ni como iniciador o fundador del modernismo, porque este es una criatura del mundo moderno, no de una persona o de un grupo. Loisy será recordado como alguien que planteó si la verdad del catolicismo romano era compatible con la verdad de la crítica bíblica y de la crítica histórica. La respuesta del Papa y los obispos ha sido una enérgica negativa ${ }^{189}$.

Al año, el 21 de marzo de 1909, fue excomulgado Romolo Murri. Había elegido diputado el día 14. Era un hecho extraño, porque Murri, decía Frederich von Hügel, era «non seulement un orthodoxe, c'est en véritable ortodoxe... "foncièrement scolastique"». Loisy subrayaba que eso importaba poco. Murri había desobedecido. Era más importante la obediencia que la ortodoxia ${ }^{190}$.

\section{LOS AÑOS POSTERIORES: CHOSES PASSÉES ${ }^{191}$}

El 3 de mayo de 1909 inició Loisy su curso en el Collège de France. Sus competidores para el puesto habían trabajado la teoría de la religión. Por eso quiso destacar lo que juzgaba su originalidad. El verdadero método en historia

${ }^{187}$ Loisy iniciaba su propia vía, que, en una carta a Frederich von Hügel, describía como un creciente desinterés de todo lo que sucedía en la Iglesia católica. Por eso «'idée d'un changement n'est pas même à discuter» Alfred LoISY, Mémoires pour servir à l'histoire religieuse de notre temps, Tome Troisième 1908-1927, Paris, Émile Nourry, Éditeur, 1931, 27-28 y 49.

188 Alfred LoISY, Mémoires..., tome III, 53-54.

189 Alfred LoISY, Mémoires..., tome III, 54.

190 Cartas de von Hügel 4 y 21 abril 1909, Alfred LoISY, Mémoires..., tome III, 95.

${ }^{191}$ En una carta de von Hügel anuncia Loisy el 16 de mayo de 1912 su intención de escribir Choses passés. Serían unas memorias, no al estilo de las Renan. Su objetivo explicar su evolución intelectual y su conducta. Pensaba en la gente de bien, capaz de juzgar imparcialmente. Las redactaría y pensaría luego si las editaba ahora o las dejaba escritas para después de su muerte, aunque no pensaba que hubiera que dejarlo para tan tarde. Mémoires..., tome III, 243. Choses passées, Paris, chez l'auteur 1913, 398. Se imprimieron poco más de 200 ejemplares.

Hispania Sacra, LIX

120, julio-diciembre 2007, 633-706, ISSN: 0018-215-X 
consiste en ver bien la significación de los testimonios y de los hechos, penetrar con profundidad y amplitud en ellos. La novedad renunciar a elaborar una teoría antes de examinar los hechos religiosos. Sobre ellos había un trabajo de erudición y una teoría social. Loisy se proponía un entendimiento directo y pleno de las realidades que constituyen la vida religiosa y las religiones ${ }^{192}$.

Ese mismo día en que Loisy inició sus lecciones sobre el sacrificio, en medio de una gran expectación ${ }^{193}$, Pioli comentaba a Giovanni Semeria su perplejidad: ¿seguir en la Iglesia dando tiempo al tiempo o emprender una acción que cambie la situación del clero? Seguir dentro en silencio o dejar que siguieran los mismos, iría reduciendo la Iglesia a una secta cerrada, donde sobrevivan la ignorancia y la superstición, una jerarquía escéptica e hipócrita, solo interesada en perpetuarse. Preguntaba a Semeria si el silencio disciplinado no equivalía a una escisión de grupos o de individuos. No compartía la visión de Albert Houtin $^{194}$, que creía imposible una reforma de la Iglesia permaneciendo dentro de ella. Pioli optaba por permanecer y anticipar en la propia conducta lo que urge que la Iglesia llegue a ser, si quiere ser una guía moral para el mundo.

El impulso debía proceder del clero y ser realizado por él. Existían personas capaces y dispuestas, pero se agotaba el tiempo. Un fracaso haría que el clero se volviera escéptico y viviera sometido. Había una crisis vocacional. Los mejores se agruparían en otros terrenos, fuera de la Iglesia, a la espera de un tiempo más favorable.

La experiencia de Francia probaba que la reducción de los católicos no suponía un cambio cualitativo, una mejora. La alternativa era ser cristianos dejando el catolicismo o disimular el cristianismo para ser católicos. Esto sólo puede resolver el problema individual, pero no salva a una Iglesia que desciende en sus efectivos sin crecer en calidad. No quedaban plazos. Había que responder a ese desaliento que se extendía en la Iglesia a grandes pasos ${ }^{195}$.

¿Había que desconfesionalizar el cristianismo? En agosto-septiembre de 1910 se celebraron por primera vez en Pontigny las «Entretiens d'été». Loisy invitó a Gallarati Scotti y Alfieri. Ninguno de los dos pudo asistir. Era una «réunion d'études en dehors de toute préoccupation confessionelle et même d'action religieuse» 196 .

192 Alfred LoIsY, Mémoires..., tome III, 101.

${ }^{193}$ Leçon d'ouverture cu cours d'Histoire des Religions au Collège de France, 1909.Un texto de 43 páginas. Su estudio sobre el tema, Essai historique sur le sacrifice, 1920, 552 páginas

${ }^{194}$ Se refiere a su obra, La crise du clergé 2e édition, Paris, Nourry 1908.

${ }^{195}$ Este análisis brotaba de la urgencia que sentía ante un asunto para él era de vida o muerte. Giovanni Pioli-Giovanni Semeria, París 3 mayo 1909, «Aspetti di una crisi religiosa», a cura di Rocco Cerrato, Fonti e Documenti 5-6 (1976-77), 606-608.

${ }^{196}$ Loisy-Gallarati Scotti, 21 mayo 1910, en Maurilio GuASCO, «Loisy e i Lombardi», Fonti e Documenti 2 (1973), 620. 
Por entonces Loisy, cada vez más distanciado de Frederich von Hügel en los planteamientos, pero no en la amistad, no deseaba debatir con él dos de sus más queridos supuestos: la posibilidad de ser ortodoxo y de trabajar en la reforma religiosa. Ambos eran para Loisy dos quimeras. No quería entrar en polémica respondiendo a la presión que el barón le hacía. Eso sería divertir a católicos, protestantes e incrédulos. Citaba a Fogazzaro, en un artículo publicado en Coenobium: Loisy no era ya ni católico ni cristiano. Respetaba su conciencia, su convicción de estar en la verdad. Añadía: «Chrétien et catholique, tel que je professe et j'ai toujours professé, je ne puis absolument me rencontrer avec lui sur un terrain commun de discussion». La postura de Fogazzaro dejaba todo igual. Nada resolvía. Estaba en la línea de la apologética ortodoxa, con mucho de prudencia y de diplomacia italiana ${ }^{197}$.

Ese verano hubo dos acontecimiento más: la condena de Le Sillon y el motu proprio Sacrorum Antistitum. La condena de Le Sillon el 25 de agosto de 1910 abre el capítulo que Loisy titula «La terreur noire». El acto formaba parte de la lucha contra el modernismo. Tocaba ahora al modernismo social. En la iniciativa estaba el arzobispo de Burdeos. Siendo obispo de Marsella, fue creado cardenal el 16 de diciembre de 1907. Era la persona de confianza del Papa dentro del episcopado.

Cuando se supo que Le Sillon estaba amenazado, Mignot envió su «Mémoire» a los obispos. Luego dirigió una carta abierta al cardenal Pierre Paulin Andrieu, el 4 de abril de 1910. En el debate entre sus enemigos y Le Sillon no estaban en juego ni la fe ni la disciplina eclesiástica, sino sólo intereses políticos. Los obispos callaron, porque sabían que la Santa Sede apoyaba al arzobispo de Burdeos. Al lado de Mignot, sólo cinco obispos, uno de ellos el cardenal Fustet, arzobispo de Rouen.

Mignot resumía la situación. Los colaboradores del Papa estaban llevando a cabo medidas contra los mejores. En este caso, contra unos jóvenes, de fe sencilla, generosos, entregados, con una espiritualidad más fuerte que la de la Action Catholique de la Jeneusse Française, bajo la influencia de los jesuitas, recordaba Loisy. Ni era democrática, ni republicana ni tenía inquietudes sociales a favor de los obreros. Le Sillon estaba vinculado a los marianistas, del Colegio Stanislas de París ${ }^{198}$.

197 Alfred LoISY, Mémoires, tomeIII, 166-167.

198 Las relaciones de Loisy con los maranistas se concretaban en su estima hacia Louis Riese. Vid. Mémoires..., tome II, 250, 258, 437, 459, 518 y tome III, 215, 303-306. Riest dejó la Compañia de María. Contrajo matrimonio. Marchó al frente, donde murió el 12 de enero de 1915. Los documentos con las conexiones Stanislas-Le Sillon, Le Sillon chez les Marianistes, a cura di Ambrogio Albino, sin lugar, pero impreso en Vercelli. Piemonte, Le Gerbe 1999.

Hispania Sacra, LIX

120, julio-diciembre 2007, 633-706, ISSN: 0018-215-X 
El arzobispo de Albi abogó por una causa ya perdida. Mignot era además una persona sospechosa y mal vista en el Vaticano desde hacía años. No tuvo en cuenta los cambios en el episcopado francés, reclutado entre personas incondicionales a Pío $\mathrm{X}^{199}$. El Papa pudo llevar adelante la condena, «l'acte le plus odieux quue Pie X a commis». No había nada doctrinal. No podría ampararse en la defensa de la ortodoxia. «Ils (les sillonnistes) n'ont péché que par l'excès de leur devouement à une institution qui ne le méritait pas»200.

El motu proprio Sacrorum Antistitum, del 1 de septiemnbre de 1910, manifestaba que aún preocupaban a Pío X los modernistas, desemmascarados, según sus palabras, en la Pascendi. El Papa hacía suyas las acusaciones de que estaban agrupados en una organización secreta, que buscaba nuevos adeptos y pretendía envenenar con sus ideas la sociedad cristiana. Loisy consideró ese acto una puesta en práctica del «programme de police inquisitoriale» diseñado en la encíclica en 1907. Existía el Sodalitium Pianum y se editaba la Correspondence de Rome. El juramento obligaba a abrazar y aceptar todas y cada una de las verdades definidas, afirmadas y declaradas por el magisterio infalible, sobre todo aquellos puntos doctrinales que se oponen directamente a los errores de este tiempo. Era una situación caótica, según Loisy. Porque con su autoridad infalible el Papa obligaba a aceptar como infalibles verdades que no lo eran ${ }^{201}$.

Nadie debe jurar que cree en aquello que no cree. Con todo, manteniendo su idea de que hay tantos modernismos como modernistas, juzgaba Loisy que cada uno debería examinar su situación, ver si podía o no hacerlo. La Pascendi definió un sistema, que nadie sostiene. Ahora el Papa hacía repudiar algo que no existía más que en la mente de quien redactó la encíclica. Eso no debía ocultar que el problema no se planteaba sobre puntos concretos, sino sobre «la prétension qu'a le pape d'empêcher littéralement les gens de penser». Quienes emitían el juramento merecían más la compasión que la reprensión ${ }^{202}$.

En el curso 1911-1912, uno de los que se sentía especialmente satisfecho, Loisy fue elaborando varios estudios. El que redactó para Hibbert Journal, según dijo a Frederich von Hügel era un anticipo de lo que será su obra Les mystères paiens et le mystère chrétien, editada en 1919 y fue reeditada en 1930.

El evangelio de Jesús no es una religión. Vino para cumplir la esperanza mesiánica de Israel. Treinta años después de su muerte, hay una religión que ha salido del Evangelio. Es una religión independiente, que se desgaja del judaísmo.

199 Alfred LoIsY, Mémoires..., tome III, 194-199.

200 Loisy-Frederich von Hügel, 5 noviembre 1910, ibidem, 207.

201 Alfred LoIsY, ibidem, 202-205.

202 Carta de Alfred Loisy al P. Hyacinthe Loyson, 31 diciembre 1910, Mémoires..., tome III, 212. 
Esto sucede antes de que desparezca la primera generación cristiana. Es un hecho que se produce a la luz del día.

El proceso fue así: el mesianismo se transforma en un misterio de salvación eterna. Se impone al resto de los misterios porque les aventaja en su doctrina sobre Dios y la inmortalidad de un salvador que vive y que tiene mayor atractivo que los otros héroes de los misterios. Se institucionaliza de una forma muy cohesionada en la doctrina y en su expresión social, Había contribuido a su éxito su exclusivismo, su decisión de «vencer o morir» ${ }^{203}$. No era mera erudición. La trayectoria recorrida por la memoria de Jesús explicaba, con el paso de los siglos, que la disciplina fuera innegociable. Cualquier disentimiento urgía a restablecer la cohesión. Las medidas disciplinares la tutelaban. Fue ella la que habría dado la victoria al «misterio cristiano» por obra de la Iglesia católica.

Los ejemplos en 1912 fueron la condena de Louis Duchesne que se sometió, pero su acto fue discreto, reducido al mínimo ${ }^{204}$. Cuando fue condenado, Gallarati Scotti se acogió a su condición de laico. Guardó silencio y explicó sus motivos en una carta a Bonomelli. Trabajaba entonces en una biografía de Fogazzaro. Le daban un aviso para disuadirlo y para que abandonara el proyecto. En cuanto a Antonietta Giacomelli, en sus escritos nada había censurable, salvo su posición contraria al poder temporal y a los jesuitas ${ }^{205}$.

En el verano de 1912 escribió Loisy: La vida no es una cadena de silogismo. Su trabajo no es tampoco una especulación metódica sobre el conjunto de las doctrinas y de las prácticas del catolicismo. Una y otro son el resultado de experiencias directas y personales que le ahorraban pensar demasiado. Los razonamientos le habrían podido hacer dudar, a pesar suyo, en su juventud. La experiencia de sus estudios, de su vida y la experiencia de los hombres, le proporcionaron la certeza que necesitaba para decidir romper con la Iglesia.

«Après tout, j'aurais pu trouver l'Église moins réfractaire à mes conclusions critiques; elle aurait pu être moins absurde et révolutionnaire dans sa politique lors de la Séparation; sis ces hommes tels que Mgr. Mignot s'y étaient rencontrés en plus grand nombre, une œuvre de réforme aurait pu être tentée où j'aurais trouvé un exercice normal de mon activité, et d'abord des motifs d'espérer et attein-

${ }^{203}$ Alfred LoISY, Ibidem, 231-232. La noticia sobre la obra Les mystères paiens et le mystère chrétien, ibidem, 277.

${ }^{204}$ Hizo Loisy un brillante sumario de lo que habían significado personas como los cardenales Richard, Meignan y Merry del Val, Mignot, «un prélat de bonne volonté pour les réformes qui apparaissaient nécessaires», y Duchesne. Era este un modelo de sacerdote intelectual, sabio, que no le gustaba. «La personnalité d'un homme n'est pas un produit logique; c'est avant tout une entité vivante, la réaction, plus ou moins accentuée, d'une individualité devant et sous l'ambiance qui la pénètre en l'environnant», Ibidem, 250.

205 Alfred LoISY, Ibidem, 241.

Hispania Sacra, LIX

120, julio-diciembre 2007, 633-706, ISSN: 0018-215-X 
dre. Il est arbitraire de croire que l'Eglise est immuable, puis qu'elle ne l'est pas réellement; c'est elle qui se paralyse en affectant de l'être». Como en otras ocasiones, Loisy lamenta que tanto él como los otros modernistas hayan sido ocasión para que la Iglesia se cerrara, en lugar de ampliarse, de ensancharse 206.

Al regresar de París a Ceffonds por la primavera, tras acabar su curso, escribió el 6 de abril de 1914 en su cuaderno de notas. La suerte de las personas ancianas célibes es morir abandonadas. La sociedad apenas les deja un lugar al sol o a la sombra durante su vida. Parece esperar impaciente que desaparezcan En su caso eso es más evidente, porque parecía ocupar un puesto reservado a un laico. Quería acabar su labor en paz. Su recompensa, saber que había cumplido con su deber. Sentía que la vida había pasado junto a él. No tenía ya tiempo para sumergirse en ella. Y el trabajo centrado en las ideas carecía de importancia. No quería dejarse engañar en ese punto.

«En ce qui me concerne je dois savoir mieux que personne le peu que valent mes élucubrations. Mais c'est ce que je peux faire de mieux, n'étant plus propre à rien autre chose. Par conséquent c'est que je dois faire... le travail est, en somme, plus sain que l'inaction, et je mourrais d'ennui plus facilement que de fatigue».

Semanas más tarde, proyectando sus lecciones para el curso 1914-1914, exponía su estado de ánimo a von Hügel el 7 de julio. Aquella nota del 6 de abril sólo reflejaba una parte de su existencia. Sentía «la solitude de ma vie privée et le désagrément résultant de je ne sais quelle défiance dans les milieux scientifiques» 207 .

Loisy quiso siempre ir a las cosas, a la realidad, no quedarse en las palabras. Era un intelectual exigente, con un gusto acentuado por la vida religiosa, por el misticismo. Su existencia tiene mucho de lucha entre el místico y el intelectual. Su labor crítica le llevó a distinguir entre el contenido y el continente, la fe y las representaciones de la fe, los datos de la experiencia religiosa y las especulaciones sobre ella.

Se puede llegar al sentimiento religioso mediante la observación. De alguna manera sus manifestaciones pueden captarse, pueden ser conocidas, al menos en sus rasgos, si no en su esencia.

Loisy creía en una relación con una potencia viva, que suscita sentimientos que iluminan toda la conducta, las grandes decisiones y la vida diaria. Importa sobre todo que esa relación impulse a la caridad con los otros y abran a las inspiraciones que de esa potencia nos llegan, aceptándolas con amor, gratuitamente, desprendidos de nosotros mismos.

206 Comentario a una carta de Paul Desjardins, 16 julio 1912, Mémoires..., tome III, 248.

207 Alfred LoISY, Ibidem, 278-279 y 281. 
Pasó así de la oración, tal como la había aprendido siendo joven, al abandono total a la voluntad de Dios, una aproximación al quietismo. La oración se identificaba con la meditación afectiva.

En su recorrido, Loisy halló a Dios, un Dios, amigo de los hombres. Había tenido la ayuda de ex jesuita Henri Bremond. Colocó esta dimensión de su vida en el primer puesto

«Peut-être traversons nous un temps d'impuissance relative dans l'ordre religieux, à moins que telle ne soit là la condition normale de l'humanité. L'important est que ce ne soit pas pour nous un temps de désespérance. Nous ne sommes pas obligé, encore une fois, de connaître le dernier mot des choses, puisque nous en sommes incapables: mais nous pouvons venir en aide, si peu que ce soit, à la pauvre humanité. Dieu est amour, dit l'Écriture, et donc l'amour, le dévouement à l'humanité est Dieu même ou la religion». Se lo decía 27 de febrero de 1918 a su amigo Boyer de Sainte-Suzanne208.

\section{«CON LA DEBIDA MODERACIÓN»}

Quien deba o quiera sacar conclusiones al acabar este recorrido no debería olvidar que la moderación fue la divisa en la que Loisy inspiró su existencia. No deseó jamas pravelecer, sino protegerse de lo que había de excesivo en la conducta de los demás. La crítica era su «disciplina» como campo de trabajo y como esfuerzo interior. Crítica era moderar la pretensión de ir más allá de la realidad y del testimonio que ella da de sí misma. La crítica se inspira en esa discreta pasión que es el amor a la verdad. El sufrimiento es el discreto peaje de quien la busca, porque en ella encuentra santuario y hogar, los de su conciencia.

El 14 de julio de 1892, Loisy reflexionaba sobre sí mismo, sobre las contradicciones de su carácter. Tímido y ambicioso, solitario, alejado de la sociedad, le gusta vivir para sí. Y, a la vez, desea influir sobre los otros, ocupar su puesto en el drama que se representa en su época. Su bonhomía tímida le ha impedido confesar sus pretensiones y hasta le empuja al desaliento. El sabio retiene al insensato. En el fondo, la razón es de éste. Hay que entregarse a favor del pobre prójimo. Para entregarse hay que dar un paso adelante. «Qui perdiderit animam suam salvam faciet eam» (Mc 8, 35).

No ambicionó jamás una buena posición. No quiso honores. Recibió en su vida más injurias que agradecimientos. Ningún obispo osaría hacerlo siquiera

\footnotetext{
208 Loisy-Raymond de Boyer de Sainte-Suzanne, 27 febrero 1918, recogido en Alfred Loisy entre la foi et l'incroyance, Paris, Centurion 1968, 34, 117-119, 134-140, 143-144, 178 y 189.

Hispania Sacra, LIX

120, julio-diciembre 2007, 633-706, ISSN: 0018-215-X
} 
canónigo honorario, recompensa que recibe cualquier eclesiástico que no haya creado problemas y haya sido moderadamente útil.

Un día más tarde, el 15 de julio 1892, escribe: «L'enseignement religieux, pour se faire accepter, ne doit prendre l'esprit humain à rebroussepoil». Y el 18 de julio: «J'ai peur seulement qu'il n'yait contradiction absolue entre les deux termes esprit ecclésiastique et changement, progrès, modernisation».

Se trazó su programa en octubre de 1889 y lo trabajó los años siguientes, afirmando en 1930, que lo había realizado. Pero en el verano de 1892 su estado de ánimo queda reflejado en su deseo de vivir retirado para cultivar un pequeño jardín, criar unos polluelos, leer autores antiguos y mirar las cosas sin tomar parte en ellas. «Vanitas vanitatum». Cuando uno ha cumplido su misión, debe retirarse. Con eso basta para justificarse en este mundo y en el otro.

En la navidad de 1893, tras su destitución, comenta a Frederich von Hügel la suspensión de L'Enseignement Biblique. Era una prueba. La mejor forma de salir de ella era retirarse bajo su tienda a trabajar. ¿Tenía otra salida? Esperaba que se le hiciera una propuesta honorable. Para que así fuera, debería mostrar que contaba aún con la confianza de la Iglesia, representada por el arzobispo de París y que le asegurara una plena libertad en su trabajo.

Semanas más tarde, el 21 de marzo de 1894 escribe una carta a Mignot. Se hablaba de su capellanía en las dominicas de Neully. Si se la dieran, se enterraría en ella o en su pueblo, si regresara a él. Este desahogo con el amigo lo consideró años más tarde injusto, porque en esa carta le decía que esa elección le permitía mantenerse honesto sin tener que alabar o recomendar la obra del sulpìciano Vigouroux. No había sabido reconocer el valor de aquellas personas que, dentro de la Iglesia, de un régimen que no dudaba en llamar tiránico, se atrevían a sostenerlo en sus dificultades. Entre esas personas, D'Hulst y sobre todo Mignot ${ }^{209}$.

Loisy se preguntaba si era necesario romper con la Iglesia porque ella estaba contra la ciencia. ¿Era la ciencia capaz de fundar un orden moral? No estaba seguro de ello. En ese momento de duda, afirma que sólo son ortodoxos los que jamás han pensado. Henri Bremond ve en esa afirmación la imposibilidad de la ortodoxia. Era ésta una noción sin contenido. No existe una doctrina inmutable. Pretender lo contrario es caer en el mito. Una doctrina invariable, afirmada como legitimidad de una religión, niega que la vida sea movimiento. No es posible inmovilizar el pensamiento humano. Eso es mucho más cierto en aquellas experiencias que la historia es incapaz de llenar plenamente.

¿Por qué seguir en la Iglesia? Porque se desea insertarla en el mundo moderno. El modernismo es una variante del reformismo. Los meros reformistas no

${ }^{209}$ Alfred LoISY, Mémoires..., tome I, 211-213, 316 y 226. 
cuestionan el postulado teológico de la ortodoxia. Los modernistas, sí. Los «progresistas», según Bremond, no perciben que la ortodoxia de Roma exige mucho a sus servidores ${ }^{210}$. Para salvar la sinceridad de Loisy, Bremond apela a la diferencia entre fe dogmática y fe mística. Loisy es leal a esta. Para Bremond la Iglesia tiene tres dimensiones o apartados: el alma, el cuerpo de los fieles y su jerarquía.

La historia mostraba que siempre había existido la necesidad de un compromiso entre la ciencia y la fe. El modernismo era un caso más. Los modernistas no se revelaban contra el tabú de la ortodoxia, actuaban como si esta no fuese un tabú.

Pero esos años esta posición era insostenible. Esa forma de coherencia intelectual no fue aceptada por la Santa Sede. Por eso Loisy fue separado y hubo de separarse 211 . Estaba seguro de que la represión nada arreglaba. La crisis afectiva de esta experiencia le haría coincidir con quienes no creían que la utopía soñada por el reformismo modernista tuviera futuro, fuera racional.

El 29 de diciembre de 1920, Loisy escribía a Eugène Maubec, un sacerdote de la diócesis de Rouen, que no hizo el juramento antimodernista. Reconocía que la historia, tal como él la presentaba podría tener efectos ruinosos sobre el dogma, si este se consideraba fuera de la historia y se integraba dentro de una filosofía.

Jesús participó de las ideas del judaísmo de su tiempo. La esperanza de salvación y la revelación cumplidas en Jesús «sont conditionnées judaïquement: elles devaient l'être».

Había que distinguir los aspectos institucionales de la Iglesia y la «action permanente du Christ immortel dans l'Église et dans les sacrements de l'Église».

¿Qué repercusiones tendría la investigación histórica? Modestamente, Loisy responde cree que los resultados de la investigación sobre los orígenes del cristianismo llevarían a «une conception plus réelle, plus intime, plus profonde de la divinité du Christ et de son action vivifiante». No supondría el vaciamiento de los dogmas católicos. «Tout cela est à la fois plus mystérieux et plus vrai qu'on n'avait cru».

210 Poulat diferencia entre progresistas y modernistas. Aquellos querían poner al servicio de la ortodoxia las adquisiciones de la ciencia. Estos pedían que se tuviera en cuenta las transformciones del espíritu humano. El desarrollo de lasciencias era uno de sus síntomas. Émile Poulat, Modernistica. Horizons, physionomies, débats, Nouvelles Éditions Latines. Paris 1982, 43.

211 «Il ne sortira que lorsque l'Église lui signifiera par l'excommunication solennelle du 7 mars 1908, qu'elle ne veut plus de lui».

Hispania Sacra, LIX

120, julio-diciembre 2007, 633-706, ISSN: 0018-215-X 
La teología, buscando formulas inmutables, se habría arriesgado a empujar la proa hacia las sombras. La gente, al ver esta sombra, al ver que es una sombra, olvidaban volverse a una realidad que es imperecedera ${ }^{212}$.

El año anterior a su excomunión, sostuvo que la Iglesia debía actuar como educadora de la humanidad y el sacerdote, como doctor indispensable de la moral. Si no lo hacían, una y otro habían perdido su razón de ser. Temía que la intransigencia acabara expulsándolo de la Iglesia. Esperaba que no se le obligara a actos contrarios a sus convicciones íntimas. Si no era así, tendrían que salir todos los creyentes liberales. Eso no llevaría de momento a une «réation féconde». Se equivocarían quienes tomaran la iniciativa de separarse.

Toda la posición de Loisy, manifiesta en sus pequeños libros, quedará desaprobada con los actos de Pío X. Condenando el modernismo, canonizaba las ideas de una revelación absoluta, sin progreso histórico, de un dogma inmutable y de una autoridad infalible de la tradición, encarnada exclusivamente en el Papa ${ }^{213}$. Comparaba su caso con el de Felicité Robert de Lamennais. Pensó servir su ideal haciéndose sacerdote, pero fue desautorizado en Francia y Roma. Era un profeta, que anunciaba un tiempo nuevo. Hizo lo que pudo. Hubo de pasar por la Iglesia para poder cumplir su misión. Sin esa experiencia no habría descubierto que la Iglesia no puede o no quiere adaptarse a este tiempo nuevo 214 .

Su pretensión era muy modesta y, pese a eso, fue rechazado por la Iglesia. En 1920 se limitaba a infundir al racionalismo intelectualista y antimístico el sentimiento de sus límites y una sana valoración del hecho religioso y moral en la educación humana. «Je ne réussis guère mieux dans cette seconde opération que dans la première». Y anadía con humor, al menos este racionalismo no lo había excomulgado como lo había hecho el «dogmatismo teológico». «Notre action est courte. Nous sommes des grains de poussière dans un tourbillon. Et dans le chais actuel, que pèsent nos pauvres réflexions?» 215 .

El 27 de enero de 1925 murió Frederich von Hügel. Dos años más tarde, se publicó Baron Frederich von Hügel, Selected Letteers, 1896-1924, Edited by a

212 Émile Poulat dossier historique previo a, Une oeuvre clandestine d'Henry Bremond. Sylvain Lebrand..., Un Clerc qui n'a pas trahi. Alfred Loisy d'après ses mémoires. 1931, Edizioni di Storia e Letteratura, Roma 1972,90-94. Texto citado en la nota anterior, 140.

213 Alfred LoISY, Mémoires..., tome II, 509-510.

214 «Mon cas, plus modeste, ne laisse pas d'être analogue à celui de Lamennais. J'aurais pu faire comme laïque à peu près ce que j'ai fait dans l'ordre de l'histoire, et de la philosophie religieuse, mais je n'aurais pas démontré par le fait l'incompatibilité du catholicisme avec la mentalité contemporaine» Carta a Raymond de Boyer de Sainte-Suzanne, 17 julio 1919, Alfred Loisy entre la foi et l'incroyance, Paris, Centurion 1968, 166.

215 Con motivo del nombramiento de Frederich von Hügel doctor honoris causa por la Universidad de Oxford, una vez más Loisy quiso aclarar ante su amigo el objetivo y los límites de su trabajo. No quiso tocar grandes temas. Alfred Loisy-von Hügel, 15 de agosto 1920, Mémoires..., tomeIII, 393-394. 
Memoir by Bernard Holland. Tras ese acontecimiento y partiendo de la comunicación de Maude H. Petre en el Congreso celebrado en abril de 1927, con motivo de su 70 aniversario, matizó Loisy la imagen de su amigo. No entendió el arreglo que hizo Frederich von Hügel para armonizar su religión, su vida, su ciencia y su permanencia dentro del catolicismo. Petre quizás lo resolvía estableciendo que Frederich von Hügel fue un santo pero no un mártir, mientras que George Tyrrell no fue un santo pero sí un mártir.

Loisy cree que Frederich von Hügel no podía ser ortodoxo afirmando la autonomía de la ciencia y de la crítica. Concluía que su amigo fue más heterodoxo que él, «par l'intensité de sa conviction; car c'est qu'il défendait contre l'orthodoxie, ce n'est été pas seulement le droit de la critique, mais ses opinions personnelles en la matière, tandis que je ne défendait pas précisément en toute rigueur mes opinions, mais seulement le droit de les avoir et d'en avoir d'autres si celles-là venaient me paraître insuffisamment fondées» ${ }^{216}$. Su pretensión era más moderada.

Unas semanas más tarde, el 11 de julio, visitó Loisy a su amigo Jules Guillemin en Maurupt-le-Montois, en el departamento del Haute Marne. Falleció el 25 de mayo de 1928. Tres semanas antes de su muerte, recibió una carta suya, «touchante, pleine de sérénité et de foie sans un mot qui pût me sembler indiscret ou me froisser. Il y a encore des saints qui ne font pas de leur fidélité à leurs croyances une menace pour le prochain» 217 . A la muerte de Paul Sabatier, el 5 de marzo de 1928, alabó su pasión por conciliar a todos. «Il appartenait à la race, encore peu nombreuse, de ceux qui veulent et qui font, selon leur pouvoir, la paix su la terre. Les haines qu'il a pu attirer par là ne sont pas pour le diminuer» 218 .

Creía Loisy haber guardado la misma fe a lo largos de sus años. La crise de la foi dans le temps présent. Essais d'histoire et de philosophie religieuses, una serie de ensayos cuyo propósito anunció a Frederich von Hügel en el verano de 1897, quería ser un compendio de la fe católica, para responder a lo que había visto en sus catecismo de perseverancia a las alumnas de Neuilly.

Pasado el tiempo, cuando redacta sus memorias, dice que el libro, no publicado, fue «une véritable somme de ce qui devait être le modernisme catholique». Reconocía sus limitaciones, pues era un programa abierto.

El libro no habría cumplido su fin, pero «je crois pouvoir dire que l'Église, en trompant mon espoir, a ruiné la foi que je lui gardais ou plutôt

216 Alfred Loisy, Ibidem, 468-471, 486 y 533. La opinión de Loisy sobre Selected Letters, ibidem, 488-485.

217 Alfred LoIsy, Mémoires..., tome III, 477.

218 Alfred LoIsY, Ibidem, 492-493.

Hispania Sacra, LIX

120, julio-diciembre 2007, 633-706, ISSN: 0018-215-X 
qu'elle m'a contraint à la reporter ailleurs». En 1930 se defendía de la acusación de agnosticismo absoluto y de nihilismo que sus críticos vieron en L'Évangile et l'Église y en Autour d'un petit livre. No se consideraba dentro de un sistema cerrado y acabado. Pretendía únicamente plantear problemas teóricos y prácticos que deberían examinarse seriamente y resolverse «sagement» 219 .

El 27 de enero de 1929 terminaba sus memorias. Meses más tarde, hizo un añadido. El 19 de noviembre de 1930 le visitó Lenert, el cura de Saint-Nicolas du Chardonnet, desde 1907. Desde 1909 su domilio en Paris pertenecía a esta parroquia. Tuvieron una larga conversación. Lenert insistió en su respeto a Loisy, que dejó claro la imposibilidad de una reconciliación suya con la Iglesia. El 30 de noviembre de 1930 escribió a Lenert que siempre trató de trabajar por la humanidad dentro de la Iglesia. Ahora trabajaba «uniment pour l'humanité». Sólo pedía que respetara su trabajo en lo que juzgaba sus últimos días y el sufrimiento de su última hora, si le llegaba en París. Le rogaba, por tanto, que se abstuviera de iniciativas que juzgaba inútiles y fuera de lugar. En los ambientes católicos se creaban fácilmente leyendas extravagantes. No quería proporcionar el menor pretexto para una sobre él. Quedaba así cerrada la relación entre ambos en este terreno 220 .

¿Qué sucedió con Loisy? Gente que faltó a su confianza publicó impresiones y notas, que parecían dar razón a quienes lo expulsaron de la Iglesia. Habría dejado de pertenecer a ella varios años antes de ser excomulgado.

El 7 de junio de 1904, respondiendo a quienes creían que sus dificultades eran sólo un paso atrás para saltar más lejos, decía que, dejando fuera los juegos de palabra, ya no creía en la divinidad de Jesucristo. Este ocupaba menos sitio en su experiencia religiosa que en la de los protestantes liberales, porque daba menos importancia que ellos a la revelación de Dios-Padre, que ellos atribuían

219 Alfred LoIsy, Ibidem, 477. El 24 de octubre de 1898 Loisy escribía a Paul Desjardins sobre la Union pour l'action morale. Le parecía que, más allá de la voluntad de su fundador, la Union se iba convirtiendo en una secta, es decir, en un símbolo exclusivo. Se critica a la Iglesia y se presentaba al sacerdote como un monstruo. La revista de la asociación era también un anatema contra toda religión positiva, ibidem, 489.

220 «C'est a fin de contenir un zèle bien intentionné, mais, en ce qui me regarde tout à fait inconsidéré, que j'ai reproduit ici ma lettre pour tous ceux qui de manière ou d'autre, elle peut intéresser», 28 de diciembre de 1930, Mémoires..., tome III, 549-550. Raymond de Boyer de SainteSuzanne fija esa entrevista con Lenert el 20 de noviembre. Lo sabía el cardenal Dubois, arzobispo de París. Al día siguiente Lenert le envió dos folletos, uno sobre el Syllabus y otro sobre la Pascendi y una medalla. Loisy le respondió el día 22. Todo seguía igual. Protestaba contra la mentalidad vigente en la Iglesia, cuyas consecuencias había sufrido «atrozmente». Al castigarlo, la Iglesia había golpeado la libertad de la ciencia y la sinceridad de quien se dedica a ella y había perdido cualquier derecho que tenía sobre su persona. Alfred Loisy entre la foi et l'incroyance, Paris, Centurion $1968,52-53,79$ y 108 . 
como mérito a Jesús. Si era algo en religión, debería ser «panthéo-positivo-humanitaire» 221 .

En febrero de 1907, creyendo que moriría pronto, encargó a Houtin que escribiera su vida. Le entregó papeles para hacerlo. Como en ellos no se hallaba su pensamiento, le confesó que no creía en Dios ni en la otra vida, ni en lo sobrenatural ni en el espíritu. Consideraba el libre albedrio una ilusión ${ }^{222}$.

Desde 1894, Loisy se planteó el problema religioso. Está presente en sus numerosas publicaciones. Ese es el fondo en el que sitúa y desea la reforma de la Iglesia hasta 1904. Desde entonces deja a un lado esa preocupación por la Iglesia, pero no por la religión. Vive esta situación establemente con un espíritu crítico y un sentimiento religioso exigente.

El 8 de enero de 1904, responde a B. Saunders, corresponsal del Times en París: guarda silencio ante la condena de la Santa Sede, por respeto a la autoridad, porque cree que es necesaria. Estaba en contra de toda censura al pensamiento y a su expresión. Era católico y seguiría siéndolo. Era crítico y no dejaría de serlo. La carta la publicó el Times el 30 de abril.

Excomulgado en marzo de 1908, siguió sus estudios, armonizando erudición y didactismo. Era sabio y educador religioso. La ortodoxia es una quimera. «Nadie es ortodoxo. La ortodoxia es la quimera de quienes jamás han pensado». Estas palabras las escribió Loisy en su diario el 31 de mayo de 1905. En 1930 reconocía que seguía creyendo en la necesidad de la religión, en el carácter divino del cristianismo. En 1918, seguramente sin haber leído L'Évolution créatrice, de Bergson, dice que se sentía más historiador que teólogo, más místico que filósofo. Era sensible a la movilidad de lo real, a su devenir.

Eso significaba que la fe pasa por el testimonio. No es pura adhesión a fórmulas bajo la garantía de la autoridad de quien las establece, sino una entrega con todo el ser. Este rasgo, que incluye esfuerzo, tensión, ascesis, se encuentra en los ambientes modernistas. La mística era compatible con la cultura moderna, posterior a la Ilustración, pues coincide con la ciencia, con su presupuesto fundamental: que la realidad se mueve, cambia. De la realidad sólo es accesible a nosotros lo que tiene de dinamismo, eso es lo único que podemos experimentar.

Loisy terminó creyendo que la revancha del modernismo sobre la Iglesia sería el hundimiento de la ortodoxia. Cuando desaparezca, también en el cristia-

${ }^{221}$ Extractos de su diario, 7 junio 1904, Albert Houtin et Félix SARTiaux, Alfred Loisy. Sa vie, Son ceuvre..., 128-129.

222 Esta confesión, que resumía sus convicciones desde hacía 20 años, turbó a Houtin. Loisy, una persona que se había empeñado en que siguiera en la Iglesia, lo había engañado. Lo hizo también con sus lectores. Sintió entonces repulsión hacia quien hasta entonces le pareció su maestro. «Fragment d'une note d'Albert Houtin sur ses relations avec Alfred Loisy», escrito en 1909, ibidem, 157-158.

Hispania Sacra, LIX

120, julio-diciembre 2007, 633-706, ISSN: 0018-215-X 
nismo, lo mejor de cada religión sobrevivirá en la «religion de l'humanité». A diferencia de Bergson, Loisy cree que el misticismo no es algo extraordinario. Consiste en el amor al prójimo, en el sacrificio humilde de cada día, en la solidaridad con quienes están a nuestro lado, con aquellos a quienes conocemos... Hay en esto, como Loisy reconoce, una influencia de Henri Bremond, un experto en la historia de la mística. La humanidad ha vivido siempre gracias a las renuncias y sacrificios, no gracias a la metafísica o a revelaciones transcendentes.

La experiencia mística se identifica como sentimiento, concepto cercano al de intuición en Bergson. El amor es el principio, porque el amor es divino. Es un amor-entrega, desinteresado, gratuito, universal, amor puro. Esta experiencia religiosa exigía otra forma de expresarse. No servía la Iglesia, sino unas asociaciones libres, cuyos sacerdotes se dedicarán a la educación moral, no al culto ${ }^{223}$.

Más allá de las interpretaciones, Loisy jamás se apartó de la moderación. La tuvo con quienes mandaban en la Iglesia. La observó como una disiciplina, porque pensó en el deber de guardar la fe de los sencillos. Así lo dijo varias ocaciones. El 16 de noviembre de 1924, William Mac Donald comentó en el New Yort Times que el modernismo estaba condenado antes de Pío X, porque era una vía que llevaba directamente al abandono de la Iglesia, como quedaba patente en la trayectoria de Loisy.

¿Qué resondió? ¿Había sido sincero en 1893, en 1903 y en 1904, antes de su ruptura abierta con la Iglesia? En aquella fecha no podía siquiera pensar en decir crudamente a León XIII que su Providentissimus Deus había sido redactada desconociendo la cuestión bíblica. No podía decir en 1903 y 1904 a los cardenales Richard y Merry del Val que su pretensión de controlar la exégesis era una insensatez.

La memoria para León XIII tras la Providentissimus demostraba que su sumisión era externa y disciplinar. Era lógica que expusiera sus reservas en 19031904. «Au fond, la grande question que j'avais à débattre avec les puissances ecclésiastiques n'était pas une question scientifique, c'était une question surtout morale, à résoudre dans les attitudes et la conduite. Un refus brutal d'obéissance à l'autorité ecclésiastique, dès le premier conflit, n'aurait pas été, da ma part, un acte de franchise, mais un acte de désespoir. Ma franchise, jusqu' en 1904, consistait à faire entendre aux autorités ecclésiastiques, avec la modération qui convenait, que leur pouvoir n'allait pas réellement jusqu'où elles prétendaient» 224 .

223 Guglielmo Forni, «Bergsonismo e modernismo, A. Loisy e la crítica del cristianésimo», Cristianesimo nella Storia XII/1 (1991), 85-118.

224 Alfred LoISY, Mémoires..., tome III, 467-468. 
Clemente Romano, tercer sucesor de Pedro como obispo de Roma, escribió a los Corintios a finales del siglo I. Los invitaba a entrar por la puerta que abre Jesús, el Mesías. Quien así lo hace y endereza sus pasos por la santidad y la justicia, cumple su misión sin perturbar a nadie. El que tiene el carisma de la fe, el que es muy capaz de explicar el conocimiento, quien es sabio para discernir lo que los demás dicen y el que es casto en su conducta, todos conocen que nadie es mayor que quien se humilla y busca el interés de los otros:

«¿Quién de vosotros es generoso, quién compasivo, quién repleto de amor? Diga: $\mathrm{Si}$ por mi causa sucedió la revuelta, la discordia y los cismas, me marcho, me voy a donde queráis y hago lo que sea mandado por el pueblo con tal de que el rebaño de Cristo se mantenga en paz con sus presbíteros establecidos. El que haga esto se procurará una gran gloria en Cristo y cualquier lugar lo recibirá pues del Señor es la tierra y su plenitud. Los que han vivido así llevaron y llevarán la conducta de Dios de la que no cabe arrepentirse»225.

Al decirle para mí será siempre un «amandus» una persona digna de amor, el arzobispo Mignot estaba en la tradición más que los que declararon a Loisy «vitandus».

L'Osservadore Romano, escribió, en su edición del 29 de junio de 1940, cuando murió Loisy: cada vida termina en el misterio. Nadie tiene derecho a penetrar en la zona que separa de la eternidad el tiempo. Para quienes se hallan fuera, sólo queda la misericordia, grande, luminosa, infinita de Dios, que escapa a la medida que el hombre usa. Por eso se le prohíbe juzgar. Sólo le deja esperar: la caridad todo lo espera, según la fórmula de San Pablo. Loisy fue un joven seminarista de Châlons, místico, ardiente, lleno de veneración a la Eucaristía y de devoción a la Virgen, admirador de Francisco de Asís. En la eternidad, habrá descubierto lo que la ciencia le haya ocultado. Se cerraba el comentario con estas palabras: «cet être qui tant a oeuvré, lutté, souffert, aura enfin aussi trouvé sa paix en Dieu»226.

225 Edición de Funk, 119-123, 125-127 y 129, textos recogidos en el Oficio de Lectura de lunes y viernes de la XIV del tiempo ordinario. CLEMENTE DE Roma, Carta a los Corintios. Introducción, traducción y notas de Juan José Ayán Clavo. Fuentes Patrísticas 4. Madrid, Ed. Ciudad Nueva 1994, 139.

226 Émile Poulat dossier historique previo a, Une oeuvre clandestine d'Henry Bremond. Sylvain Lebrand, Un Clerc qui n'a pas trahi. Alfred Loisy d'après ses mémoires. 1931, Edizioni di Storia e Letteratura, Roma 1972, 85-87.

Hispania Sacra, LIX

120, julio-diciembre 2007, 633-706, ISSN: 0018-215-X 